\title{
¿USES
}

Prepared in cooperation with the U.S. Department of the Army

Hydrogeology and Water Quality of the Floridan Aquifer System and Effect of Lower Floridan Aquifer Pumping on the Upper Floridan Aquifer at Hunter Army Airfield, Chatham County, Georgia

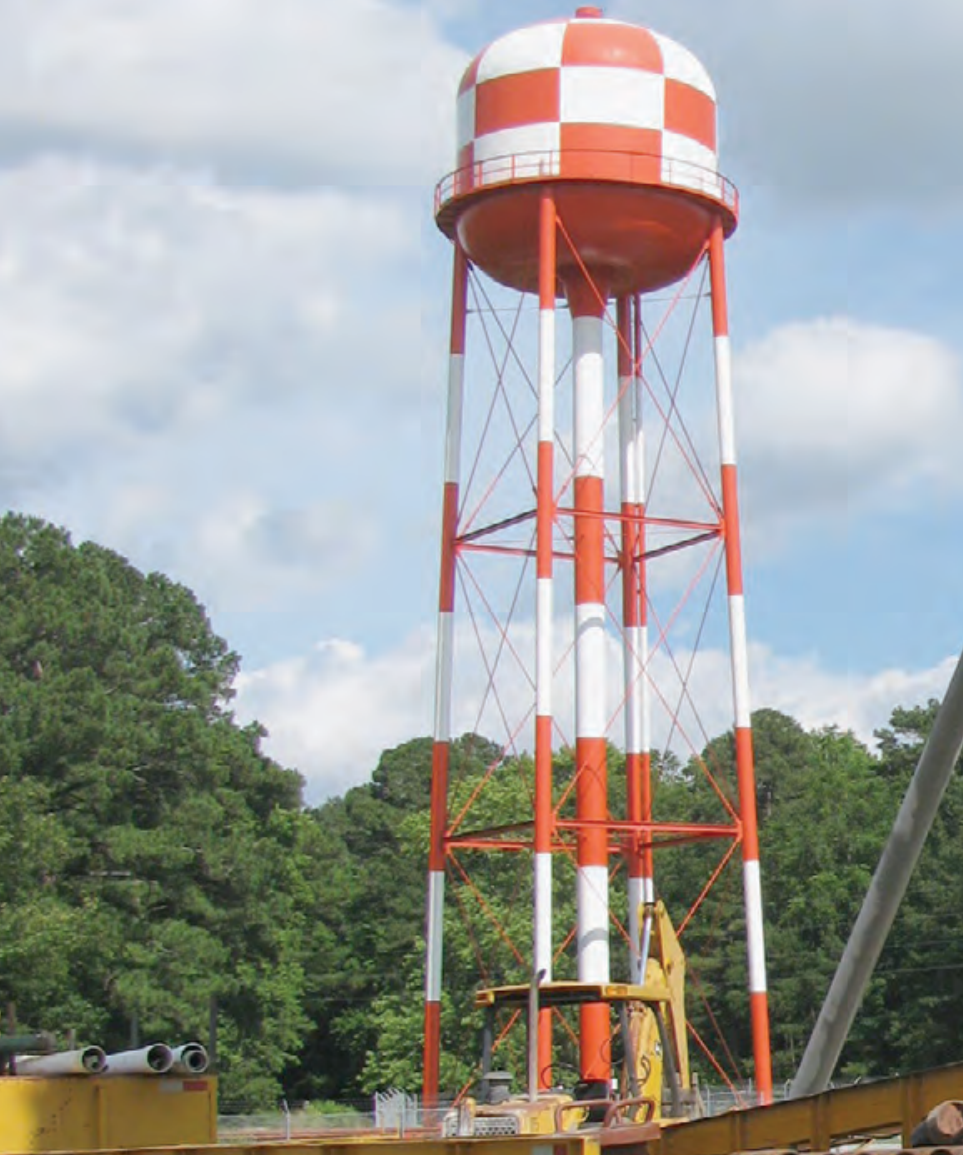


Cover. Drill rig used to install Lower Floridan production well, Hunter Army Airfield, Savannah, GA. Photo by 0 . Gary Holloway, USGS. 


\section{Hydrogeology and Water Quality of the Floridan Aquifer System and Effect of Lower Floridan Aquifer Pumping on the Upper Floridan Aquifer at Hunter Army Airfield, Chatham County, Georgia}

By John S. Clarke, Lester J. Williams, and Gregory C. Cherry

Prepared in cooperation with the U.S. Department of the Army

Scientific Investigations Report 2010-5080 


\section{U.S. Department of the Interior \\ KEN SALAZAR, Secretary \\ U.S. Geological Survey \\ Marcia K. McNutt, Director}

\section{U.S. Geological Survey, Reston, Virginia: 2010}

For more information on the USGS - the Federal source for science about the Earth, its natural and living resources, natural hazards, and the environment, visit http://Www.usgs.gov or call 1-888-ASK-USGS

For an overview of USGS information products, including maps, imagery, and publications, visit $h$ ttp://www.usgs.gov/pubprod

To order this and other USGS information products, visit http://store.usgs.gov

Any use of trade, product, or firm names is for descriptive purposes only and does not imply endorsement by the U.S. Government.

Although this report is in the public domain, permission must be secured from the individual copyright owners to reproduce any copyrighted materials contained within this report.

Suggested citation:

Clarke, J.S., Williams, L.J., and Cherry G.C., 2010, Hydrogeology and water quality of the Floridan aquifer system and effect of Lower Floridan aquifer pumping on the Upper Floridan aquifer at Hunter Army Airfield, Chatham County, Georgia: U.S. Geological Survey Scientific Investigations Report 2010-5080, 56 p. 


\section{Contents}

Abstract
Introduction
Purpose and Scope
Water Use
Hydrogeologic Setting




\section{Figures}

1. Maps showing location of groundwater-flow model area, selected wells, and tidal station at Hunter Army Air Field and vicinity, coastal Georgia.

2. Generalized correlation of geologic and hydrogeologic units and model layers in the coastal plain of Georgia (modified from Payne and others, 2005)

3. Schematic diagram showing conceptual model of predevelopment and modern-day (2000) flow system.

4. Well-construction diagram for well HAAF 11 (360392) completed in the Lower Floridan aquifer, Hunter Army Airfield, Chatham County, Georgia, 2009.

5. Selected borehole geophysical data from well HAAF 11 (360392). Percentage flow contribution determined from flowmeter survey in open borehole, 333-1,168 feet, Hunter Army Airfield, Chatham County, Georgia .

6. Borehole flowmeter data from well HAAF 11 (360392), Hunter Army Airfield, Chatham County, Georgia

7-8. Graphs showing-

7. Specific conductance of drilling fluids while drilling well HAAF 11 (360392), Hunter Army Airfield, Chatham County, Georgia, 2009.

8. Distribution of selected chemical properties and constituent concentrations by sampled depth at well HAAF 11 (360392),

Hunter Army Airfield, Chatham County, Georgia, July 2009.

9. Trilinear diagram showing composition of major ions at various depths at well HAAF 11 (360392), Hunter Army Airfield, Chatham County, Georgia, July 2009 ......17

10-13. Graphs showing-

10. Comparison of water levels at well HAAF 8 (360292) to background water levels at Morrison Plantation observation well (360020) and to stage and barometric pressure at tidal gage 02198773, February 12-25, 2009 .......20

11. Effects of different time series components on development of a synthetic water level used to filter out extraneous trends from well HAAF 8 (360292), Hunter Army Airfield, Chatham County, Georgia

12. Logarithmic plot of drawdown and time for observation well HAAF 8 (360292) during Upper Floridan aquifer test conducted in well HAAF 9 (360391), Hunter Army Airfield, Chatham County, Georgia, February 17-18, 2009

13. Semi-logarithmic plots of drawdown and time and residual drawdown and $t / t$ ' for aquifer test of Lower Floridan aquifer at well HAAF 11 (360392), Hunter Army Airfield, Chatham County, Georgia, August 13-16, 2009

14. Map and graphs showing location and construction characteristics of wells used for aquifer tests at Hunter Army Airfield, Chatham County, Georgia

15-16. Graphs showing-

15. Water levels in the pumped Lower Floridan well (HAAF 11, 360392) and in Upper Floridan observation wells HAAF 8 (360292) and HAAF 5 (360288) before, during, and after the 72-hour aquifer test of the Lower Floridan aquifer, Hunter Army Airfield, Chatham County, Georgia, August 11-19, 2009.

16. Estimated drawdown calculated in Upper Floridan wells (A) HAAF 8 (360292) and (B) HAAF 5 (360288) during the 72-hour aquifer test of the Lower Floridan aquifer in well HAAF 11 (360392), Hunter Army Airfield, Chatham County, Georgia... 
17-18. Maps showing-

17. Simulated steady-state drawdown in the Lower Floridan aquifer resulting from pumping well HAAF 11 (360392) at 748 gallons per minute, Hunter Army Airfield and vicinity, coastal Georgia.

18. Simulated steady-state drawdown in the Upper Floridan aquifer resulting from pumping well HAAF 11 (360392) at 748 gallons per minute, Hunter Army Airfield and vicinity, coastal Georgia.

19. Block diagram showing change in simulated steady-state water budget resulting from initiation of pumping at well HAAF 11 (360392), Hunter Army Airfield, Chatham County, Georgia

20. Maps showing percentage of interaquifer leakage from the Upper Floridan aquifer contributing flow to well HAAF 11 (360392) pumping at a rate of 748 gallons per minute (1.08 million gallons per day), Hunter Army Airfield and vicinity, coastal Georgia

21. Profile showing simulated steady-state drawdown in the Upper and Lower Floridan aquifers resulting from pumping in the Lower Floridan aquifer at well HAAF 11 (360392) and from pumping the Upper Floridan aquifer at rates of 189 and 650 gallons per minute at a hypothetical Upper Floridan aquifer well at the site of well HAAF 11 (360392), Hunter Army Airfield and vicinity, coastal Georgia.

22-25. Maps showing-

22. Simulated drawdown in the Upper Floridan aquifer resulting from pumping a hypothetical Upper Floridan aquifer well at the site of well HAAF 11 (360392) at rates of 189 and 650 gallons per minute, Hunter Army Airfield and vicinity, coastal Georgia.

23. Drawdown in the Upper Floridan aquifer for scenario A-effect of pumping the Lower Floridan aquifer at well HAAF 11 (360392) at a rate of 748 gallons per minute, and reducing pumping in existing Upper Floridan aquifer HAAF supply wells by 187 gallons per minute or 25 percent of well HAAF 11 (360392) pumping rate-Hunter Army Airfield and vicinity, coastal Georgia

24. Drawdown in the Upper Floridan aquifer for scenario B - effect of pumping the Lower Floridan aquifer at well HAAF 11 (360392) at a rate of 748 gallons per minute, and reducing pumping in existing Upper Floridan aquifer supply wells by 374 gallons per minute or 50 percent of the well HAAF 11 (360392) pumping rate-Hunter Army Airfield and vicinity, coastal Georgia

25. Simulated Upper Floridan aquifer potentiometric surfaces for the 2005 base case and scenarios A, B, and C, Hunter Army Airfield and vicinity, coastal Georgia 


\section{Tables}

1. Average daily groundwater withdrawal at Hunter Army Airfield, 2002-2008.

2. Well-construction and location information for selected wells at Hunter Army Airfield and vicinity.

3. Chronology of drilling, logging, and testing in Lower Floridan Well HAAF 11 (360392), Hunter Army Airfield, Chatham County, Georgia, 2009.

4. Lithologic description of rock cuttings, well HAAF 11 (360392), Hunter Army Airfield, Chatham County, Georgia....

5. Water-quality analysis of samples collected at selected depths in well HAAF 11 (360392), Hunter Army Airfield, Chatham County, Georgia, June and August 2009 ........16

6. Vertical hydraulic conductivity and porosity of core samples collected from the Lower Floridan aquifer at well HAAF 11 (360392), Hunter Army Airfield, Chatham County, Georgia

7. Horizontal hydraulic conductivity determined from packer-slug tests at well HAAF 11 (360392), Hunter Army Airfield, Chatham County, Georgia

8. Summary of aquifer tests conducted in Upper and Lower Floridan aquifer wells at Hunter Army Airfield, Chatham County, Georgia, 2009.

9. Simulated steady-state water budget for 2000 and after initiation of pumping 748 gallons per minute (1.08 million gallons per day) at well HAAF 11 (360392), Hunter Army Airfield, Chatham County, Georgia

10. Simulated pumping and drawdown for the year 2005 permitted pumping rate and model scenarios $A, B$, and $C$

11. Projected reductions in Upper Floridan aquifer permitted capacity and net gain in total water capacity for various pumping periods, well HAAF 11 (360392), Hunter Army Airfield, Chatham County, Georgia.....

\section{Acknowledgments}

The authors appreciate the assistance of the U.S. Army, AECOM, Inc., and Oak Ridge National Laboratory for providing onsite support and data. Special thanks go to Stanley Thomas, Eric Stulpin, Tressa Rutland, and Nathaniel Williams, II, of the U.S. Army Environmental Protection and Compliance Branch. Peter Thibodeau and John Funk of AECOM, Inc., provided valuable technical support, review, and guidance regarding testing procedures employed at the site. Robert McManus of AECOM provided onsite logistical support and safety monitoring. O. Gary Holloway and Michael D. Hamrick, USGS, monitored drill site activities and collected hydrogeologic and water-quality data. Michael Register of Martin Drilling provided valuable assistance for onsite data collection. Debbie Warner Gordon and L. Elliott Jones, USGS, provided valuable support in conducting model simulations, and Jaime A. Painter, USGS, provided spatial analysis of data for model simulations and output. Lucy E. Edwards and Colleen Durand (USGS, Reston, VA) provided information on the paleontology and stratigraphic interval of core collected at the site. 


\section{Conversion Factors and Datums}

\begin{tabular}{|c|c|c|}
\hline Multiply & By & To obtain \\
\hline \multicolumn{3}{|c|}{ Length } \\
\hline inch & 2.54 & centimeter $(\mathrm{cm})$ \\
\hline foot $(\mathrm{ft})$ & 0.3048 & meter $(\mathrm{m})$ \\
\hline mile (mi) & 1.609 & kilometer (km) \\
\hline \multicolumn{3}{|c|}{ Area } \\
\hline square foot $\left(\mathrm{ft}^{2}\right)$ & 929.0 & square centimeter $\left(\mathrm{cm}^{2}\right)$ \\
\hline square foot $\left(\mathrm{ft}^{2}\right)$ & 0.0929 & square meter $\left(\mathrm{m}^{2}\right)$ \\
\hline square mile $\left(\mathrm{mi}^{2}\right)$ & 259.0 & hectare (ha) \\
\hline square mile $\left(\mathrm{mi}^{2}\right)$ & 2.590 & square kilometer $\left(\mathrm{km}^{2}\right)$ \\
\hline \multicolumn{3}{|c|}{ Volume } \\
\hline gallon (gal) & 3.785 & liter $(\mathrm{L})$ \\
\hline gallon (gal) & 0.003785 & cubic meter $\left(\mathrm{m}^{3}\right)$ \\
\hline gallon (gal) & 3.785 & cubic decimeter $\left(\mathrm{dm}^{3}\right)$ \\
\hline million gallons (Mgal) & 785 & cubic meter $\left(\mathrm{m}^{3}\right)$ \\
\hline \multicolumn{3}{|c|}{ Flow rate } \\
\hline foot per day (ft/d) & 0.3048 & meter per day $(\mathrm{m} / \mathrm{d})$ \\
\hline gallon per minute (gal/min) & 0.06309 & liter per second $(\mathrm{L} / \mathrm{s})$ \\
\hline gallon per day (gal/d) & 0.003785 & cubic meter per day $\left(\mathrm{m}^{3} / \mathrm{d}\right)$ \\
\hline million gallons per day $(\mathrm{Mgal} / \mathrm{d})$ & 0.04381 & cubic meter per second $\left(\mathrm{m}^{3} / \mathrm{s}\right)$ \\
\hline \multicolumn{3}{|c|}{ Specific capacity } \\
\hline $\begin{array}{l}\text { gallon per minute per foot } \\
[(\mathrm{gal} / \mathrm{min}) / \mathrm{ft})]\end{array}$ & 0.207 & $\begin{array}{l}\text { liter per second per meter } \\
{[(\mathrm{L} / \mathrm{s}) / \mathrm{m}]}\end{array}$ \\
\hline \multicolumn{3}{|c|}{ Hydraulic conductivity } \\
\hline foot per day (ft/d) & 0.3048 & meter per day $(\mathrm{m} / \mathrm{d})$ \\
\hline \multicolumn{3}{|c|}{ Transmissivity* } \\
\hline foot squared per day $\left(\mathrm{ft}^{2} / \mathrm{d}\right)$ & 0.0929 & meter squared per day $\left(\mathrm{m}^{2} / \mathrm{d}\right)$ \\
\hline
\end{tabular}

Vertical coordinate information is referenced to the National Geodetic Vertical Datum of 1929 (NGVD 29) or the North American Vertical Datum of 1988 (NAVD 88).

Horizontal coordinate information is referenced to North American Datum of 1983 (NAD 83).

Altitude, as used in this report, refers to distance above the vertical datum.

*Transmissivity: The standard unit for transmissivity is cubic foot per day per square foot times foot of aquifer thickness [(ft'/d)/ft²] ft. In this report, the mathematically reduced form, foot squared per day $\left(\mathrm{ft}^{2} / \mathrm{d}\right)$, is used for convenience.

Specific conductance is given in microsiemens per centimeter at 25 degrees Celsius $(\mu \mathrm{S} / \mathrm{cm}$ at $\left.25^{\circ} \mathrm{C}\right)$.

Concentrations of chemical constituents in water are given either in milligrams per liter (mg/L) or micrograms per liter $(\mu \mathrm{g} / \mathrm{L})$. 



\title{
Hydrogeology and Water Quality of the Floridan Aquifer System and Effect of Lower Floridan Aquifer Pumping on the Upper Floridan Aquifer at Hunter Army Airfield, Chatham County, Georgia
}

\author{
By John S. Clarke, Lester J. Williams, and Gregory C. Cherry
}

\section{Abstract}

Test drilling and field investigations, conducted at Hunter Army Airfield (HAAF), Chatham County, Georgia, during 2009, were used to determine the geologic, hydraulic, and water-quality characteristics of the Floridan aquifer system and to evaluate the effect of Lower Floridan aquifer (LFA) pumping on the Upper Floridan aquifer (UFA). Field investigation activities included (1) constructing a 1,168-foot (ft) test boring and well completed in the LFA, (2) collecting drill cuttings and borehole geophysical logs, (3) collecting core samples for analysis of vertical hydraulic conductivity and porosity, (4) conducting flowmeter and packer tests in the open borehole within the UFA and LFA, (5) collecting depthintegrated water samples to assess basic ionic chemistry of various water-bearing zones, and (6) conducting aquifer tests in the new LFA well and in an existing UFA well to determine hydraulic properties and assess interaquifer leakage. Using data collected at the site and in nearby areas, model simulation was used to quantify the effects of interaquifer leakage on the UFA and to determine the amount of pumping reduction required in the UFA to offset drawdown resulting from the leakage.

Borehole-geophysical and flowmeter data indicate the LFA at HAAF consists of limestone and dolomitic limestone between depths of 703 and 1,080 ft, producing water from six major permeable zones: 723-731; 768-785; 818-837; 917-923; 1,027-1,052; and 1,060-1,080 ft. Data from a flowmeter survey, conducted at a pumping rate of 748 gallons per minute (gal $/ \mathrm{min})$, suggest that the two uppermost zones contributed $469 \mathrm{gal} / \mathrm{min}$ or 62.6 percent of the total flow during the test. The remaining four zones contributed from 1.7 to 18 percent of the total flow. Grab water samples indicate that with the exception of fluoride, constituent concentrations in the LFA increased with depth; water from the deepest interval $(1,075 \mathrm{ft})$ contained chloride and sulfate concentrations of 480 and 240 milligrams per liter (mg/L), respectively. These relatively high concentrations were interpreted to have little effect on the overall quality of the well because flowmeter results indicated that water from 1,060 to $1,080 \mathrm{ft}$ contributed less than 2 percent of the total flow to the completed well.

Results of a 72-hour aquifer test indicate that pumping a LFA well at a rate of $748 \mathrm{gal} / \mathrm{min}$ produced a drawdown response of $0.76 \mathrm{ft}$ in a well completed in the UFA located $176 \mathrm{ft}$ from the pumped well. A revised regional groundwaterflow model was used to simulate long-term (steady-state) leakage response of the UFA to pumping from the LFA and to estimate the equivalent amount of pumping from the UFA that would produce similar drawdown. Pumping the well at a rate of $748 \mathrm{gal} / \mathrm{min}$ (about 1 million gallons per day [Mgal/d]) resulted in a maximum simulated steady-state drawdown of $36.2 \mathrm{ft}$ in the LFA and was greater than $1 \mathrm{ft}$ over a 146 squaremile area. Simulated steady-state drawdown in the overlying UFA that resulted from interaquifer leakage was greater than $1 \mathrm{ft}$ over a 141 square-mile area and was $2.03 \mathrm{ft}$ at the pumped well. Flow to the pumped well was derived from increased lateral flow across the specified-head boundary $(0.02 \mathrm{Mgal} / \mathrm{d})$ and increased leakage from the UFA $(0.52 \mathrm{Mgal} / \mathrm{d})$, and by reductions in discharge to the Lower Floridan confining unit $(0.53 \mathrm{Mgal} / \mathrm{d})$ and to the lateral specified-head boundary $(0.53 \mathrm{Mgal} / \mathrm{d})$. Sixty-five percent of the leakage from the UFA occurred within 1 mile of the pumped well. This larger contribution results from a larger head gradient between the pumped well and the overlying aquifer in areas close to the pumped well.

The Georgia Environmental Protection Division interim permitting strategy for the LFA requires simulation of (1) aquifer leakage from the UFA to LFA resulting from 
pumping the new LFA well, and (2) the equivalent rate of UFA pumping that induces the identical maximum drawdown in the UFA that would be expected as a result of pumping the LFA. Results of this analysis can be used as a basis to reduce nearby UFA permitted pumping in the same general area (within a 5-mile radius) by an amount equal to or greater than the determined leakage rate. Results of model simulations indicate that these two requirements result in widely varying pumping offsets for the UFA. Simulated interaquifer leakage was $361 \mathrm{gal} / \mathrm{min}(0.52 \mathrm{Mgal} / \mathrm{d})$, whereas the equivalent UFA pumping rate to offset maximum drawdown was $189 \mathrm{gal} / \mathrm{min}$ $(0.27 \mathrm{Mgal} / \mathrm{d})$. The simulated pumping rate to match the maximum drawdown in the UFA underpredicts the amount of pumping offset because the cone of depression formed in response to pumping the UFA is steeper near the pumped well and covers a smaller area than the area simulated in response to interaquifer leakage. Thus, the simulated leakage rate may be a more effective means of evaluating required pumping offsets.

Three groundwater-pumping scenarios were run to evaluate the effect of various pumping changes on groundwater levels at HAAF. For two of the scenarios, the LFA was pumped 24 hours per day at a rate of $748 \mathrm{gal} / \mathrm{min}$, while pumping from UFA wells was reduced by $187 \mathrm{gal} / \mathrm{min}$ for the first scenario and $361 \mathrm{gal} / \mathrm{min}$ for the second scenario. The third scenario involved pumping the LFA well 24 hours per day at a rate of $374 \mathrm{gal} / \mathrm{min}$ and reducing pumping of the UFA by $187 \mathrm{gal} / \mathrm{min}$. These pumpage reduction scenarios decreased the magnitude and extent of drawdown in the UFA in comparison to the scenario in which the LFA was pumped without adjusting withdrawal from the UFA. None of the scenarios resulted in noticeable changes in the configuration of the simulated potentiometric surface and related groundwater-flow directions for the UFA.

\section{Introduction}

Hunter Army Airfield (HAAF) is located in the coastal area of Georgia near the city of Savannah (fig. 1). Water supply at the facility is derived from groundwater withdrawal from wells completed in the Upper Floridan aquifer (UFA). Concern over saltwater intrusion at Hilton Head Island, South Carolina, has resulted in increased restrictions by the Georgia Environmental Protection Division (GaEPD) on permitted groundwater withdrawals from the UFA. The current UFA groundwater permit at HAAF has been modified to reduce capacity from 1.03 to 0.98 million gallons per day (Mgal/d). To meet growing demands for water in the coastal Georgia area, GaEPD has encouraged use of alternative sources of water to the UFA, including wells completed in the Lower Floridan aquifer (LFA). HAAF seeks to offset reductions in permitted withdrawals from the UFA by making up the capacity using a well completed in the LFA.
Pumping from the LFA may increase the head gradient locally between the UFA and LFA, lower water levels in the UFA, and induce leakage (groundwater flow) from the UFA to the LFA. In January 2003, GaEPD released an interim strategy for permitting Lower Floridan withdrawals in the 24-county coastal area of Georgia (Nolton Johnston, Georgia Environmental Protection Division, written commun., January 28,2003$)$. The GaEPD permitting strategy states:

"The applicant must demonstrate, using detailed aquifer testing and standard hydrogeological methods, that their LF [Lower Floridan] aquifer withdrawal does not induce downward leakage from the UF [Upper Floridan] aquifer and will have no net negative impact on water levels in the UF aquifer, or:

"If the aquifer tests do show that there is an impact on water levels in the UF aquifer because of production from the LF aquifer, the applicant must calculate, using an approved hydrologic analysis, the UF contribution to the LF well. Then, using the information from the hydrogeological studies, the applicant must reduce nearby current UF withdrawals in an amount equal to any induced leakage from the UF into the LF. In other words, the applicant must offset the impact of the LF pumping by reducing nearby UF permitted pumping in the same general area (within a 5-mile (mi) radius) by an amount equal to or greater than the determined UF leakage. This will assure continued protection of the UF aquifer under the no net negative impact policy."

As part of the interim permitting strategy, GaEPD provided a hydrogeological study protocol that states (Nolton Johnston, Georgia Environmental Protection Division, written commun., January 28, 2003): "The applicant must conduct site-specific hydrogeological testing to obtain the data needed for development of a groundwater model capable of determining the contribution from the UFA that would result from the proposed withdrawal from the LFA. This information would be used to develop a new groundwater model, which would be run to simulate the equivalent Upper Floridan pumping that induces the identical maximum drawdown in the Upper Floridan that would be expected as a result of pumping the Lower Floridan."

To assess the water-supply potential of the LFA, the U.S. Geological Survey (USGS), in cooperation with the U.S. Department of the Army, conducted an investigation during 2009 to determine the hydrogeology and water quality of the Floridan aquifer system and the potential effect that pumping from the LFA would have on the UFA. The study included construction of a test well in the LFA, detailed site investigations, and groundwater-modeling studies. 

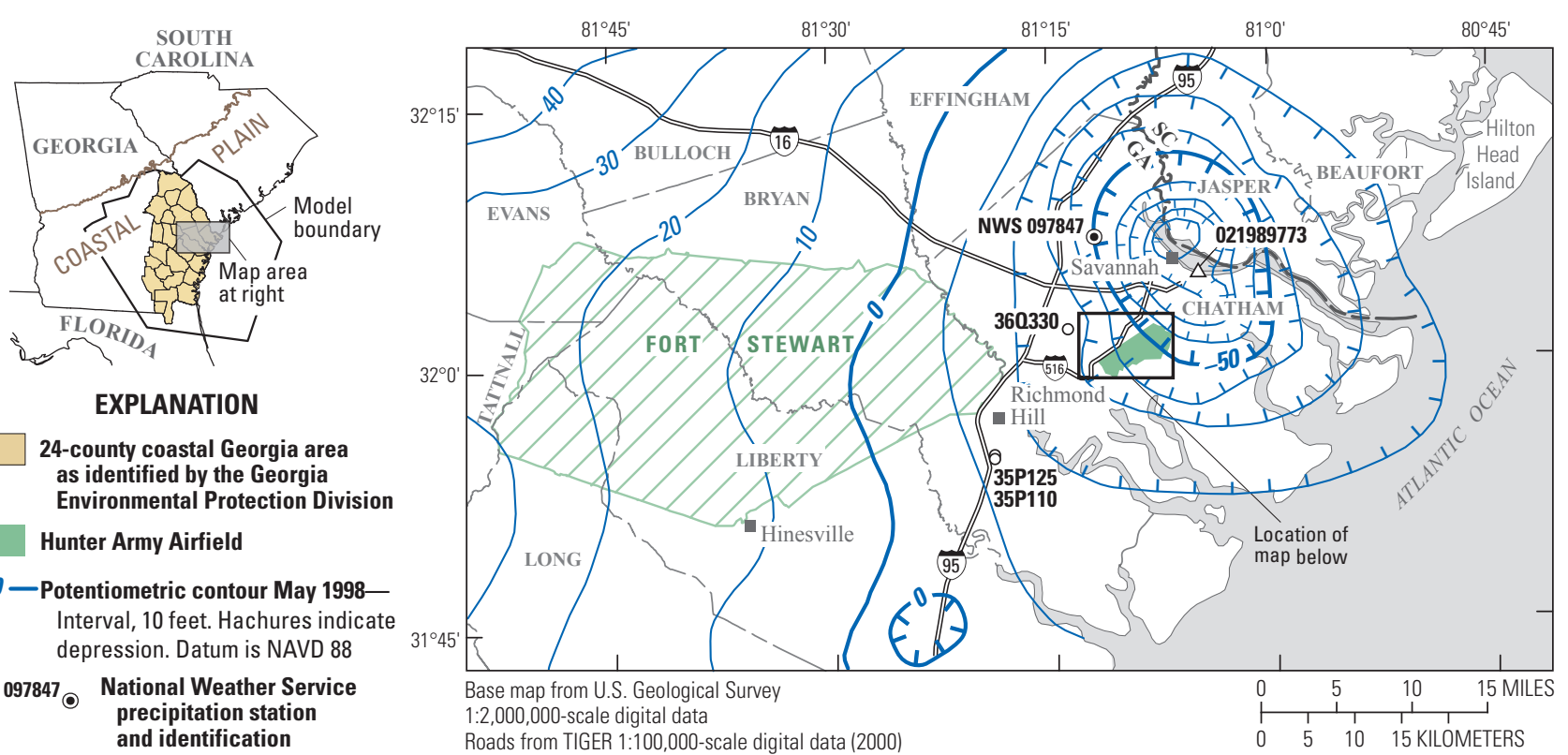
$\triangle$

\section{EXPLANATION}

24-county coastal Georgia area as identified by the Georgia Environmental Protection Division Hunter Army Airfield

- 0 - Potentiometric contour May 1998Interval, 10 feet. Hachures indicate depression. Datum is NAVD 88

NWS $097847 \odot \begin{gathered}\text { National Weather Service } \\ \text { precipitation station }\end{gathered}$ and identification

$\triangle \triangle^{021989773}$ Tidal station and identification

Roads from TIGER 1:100,000-scale digital data (2000)

Well HAAF 1 Well-Hunter Army Airfield identification; U.S.

(360285) Geological Survey identification in parentheses

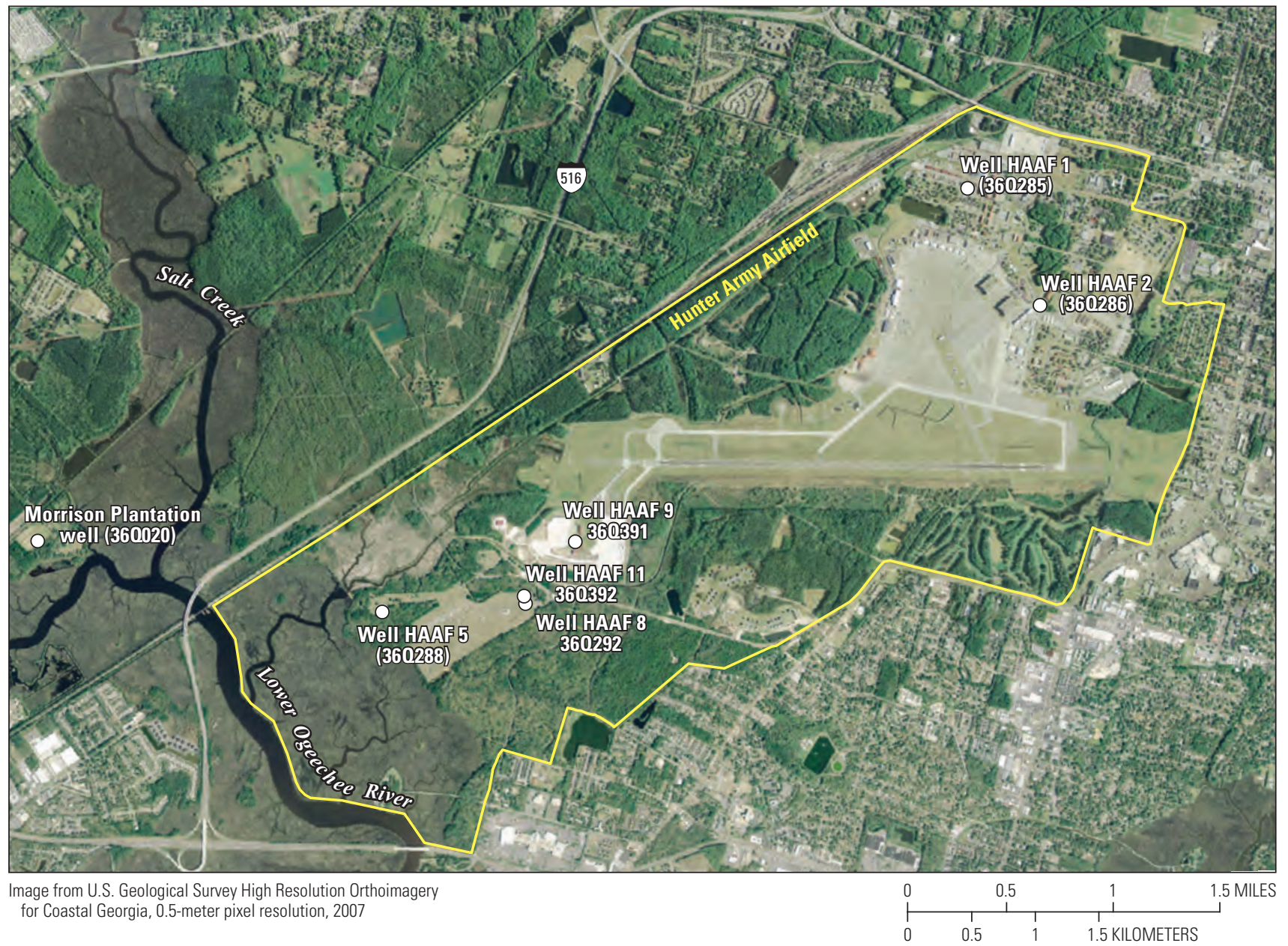

Figure 1. Location of groundwater-flow model area, selected wells, and tidal station at Hunter Army Air Field and vicinity, coastal Georgia (potentiometric contours modified from Peck and others, 1999). 


\section{Purpose and Scope}

This report documents results of field investigations and groundwater-model simulations conducted at HAAF during 2009 to determine the hydrogeology and water quality of the Floridan aquifer system and to provide data needed to assess the effect of LFA pumping on the UFA, specifically to

- Evaluate leakage response in a nearby well completed in the UFA to pumping from the LFA, and

- Quantify the amount of pumpage reduction in the Upper Floridan well (or wells) required to offset leakage and the amount of drawdown induced by leakage.

Field investigations included:

- Constructing a 1,168-foot (ft) test boring and constructing a test well completed in the LFA;

- Collecting drill cuttings and borehole geophysical logs at the test well;

- Collecting core samples, in the test well, for analysis of vertical hydraulic conductivity and porosity;

- Conducting flowmeter and packer tests in the open borehole within the UFA and LFA in the test well;

- Collecting depth-integrated water samples to assess basic ionic chemistry of various water-bearing zones in the test well; and

- Conducting aquifer tests in the LFA test well and in the existing UFA wells to determine hydraulic properties and assess interaquifer leakage.

The effects of interaquifer leakage on the UFA were quantified through simulation using a modified groundwaterflow model of coastal Georgia (Payne and others, 2005).

The groundwater model was used to quantify the amount of pumping reduction required in the UFA to offset drawdown from leakage resulting from pumping the LFA.

\section{Site Description}

The U.S. Department of the Army (U.S. Army) Fort Stewart and HAAF, Georgia, are home to the 3rd Infantry Division. HAAF is the focus of this investigation and is located in the Georgia Coastal Plain in central Chatham County, Georgia (fig. 1). The site is characterized by flat topography, with sandy topsoil typical of the Georgia coastal area.

The study area has a mild climate with warm, humid summers and mild winters. Long-term climatic patterns in the area are derived from records provided by the National Weather Service Station at Savannah International Airport (097847). During 1971-2000, precipitation at station 097847 averaged about 49 inches per year (in/yr). Maximum monthly rainfall (exceeding 4 inches per month) generally occurs during June-September, with monthly rainfall totals averaging less than 4 inches during the rest of the year. Mean monthly pan evaporation at station 097847 during 1965-2003 ranged from 2.43 to 8.49 inches per month, with the greatest evaporation during April-August.

\section{Water Use}

Water supply at HAAF is provided by four wellsHAAF 1, 2, 8, and 9-completed in the UFA, with a GaEPD permit limit of $1.03 \mathrm{Mgal} / \mathrm{d}$ in 2009. During 2002-2008, average monthly withdrawal exceeded $1 \mathrm{Mgal} / \mathrm{d}$ during the peak period from April through July and annual averages ranged from $0.78 \mathrm{Mgal} / \mathrm{d}$ in 2005 to $1.0 \mathrm{Mgal} / \mathrm{d}$ in 2007 (table 1). GaEPD has requested that the 2009 permitted withdrawal rate be reduced by $0.05 \mathrm{Mgal} / \mathrm{d}$ to a rate of $0.98 \mathrm{Mgal} / \mathrm{d}$ by July 2010 (Stanley Thomas, U.S. Department of the Army, oral commun., February 19, 2010).

Table 1. Average daily groundwater withdrawal at Hunter Army Airfield, 2002-2008 (data from Julia Fanning, U.S. Geological Survey, written commun., February 2010).

\begin{tabular}{lllllllllllllll}
\hline & \multicolumn{10}{c}{ Year } & \multicolumn{10}{c}{ Jan } & Feb & Mar & Apr & May & June & July & Aug & Sept & Oct & Nov & Dec & $\begin{array}{c}\text { Annual } \\
\text { average }\end{array}$ \\
\hline 2002 & 0.81 & 0.96 & 0.98 & 1.18 & 1.29 & 1.07 & 1.04 & 1.02 & 0.86 & 0.61 & 0.60 & 0.58 & $\mathbf{0 . 9 2}$ \\
2003 & 0.62 & 0.77 & 0.86 & 0.77 & 0.89 & 0.84 & 0.95 & 0.93 & 0.93 & 0.95 & 0.80 & 0.75 & $\mathbf{0 . 8 4}$ \\
2004 & 0.85 & 0.71 & 0.91 & 1.09 & 1.44 & 1.23 & 1.11 & 1.04 & 0.92 & 0.87 & 0.82 & 0.74 & $\mathbf{0 . 9 8}$ \\
2005 & 0.67 & 0.65 & 0.60 & 0.84 & 0.82 & 0.75 & 0.97 & 0.92 & 0.99 & 0.75 & 0.80 & 0.62 & $\mathbf{0 . 7 8}$ \\
2006 & 0.68 & 0.67 & 0.83 & 1.08 & 1.09 & 1.10 & 1.07 & 1.11 & 0.87 & 0.95 & 0.91 & 0.81 & $\mathbf{0 . 9 3}$ \\
2007 & 0.91 & 0.70 & 0.87 & 1.26 & 1.28 & 1.24 & 1.12 & 1.11 & 0.95 & 1.03 & 0.92 & 0.63 & $\mathbf{1 . 0 0}$ \\
2008 & 0.80 & 0.74 & 0.68 & 0.89 & 1.30 & 1.21 & 1.06 & 0.81 & 1.12 & 1.15 & 0.67 & 0.79 & $\mathbf{0 . 9 3}$ \\
Average & $\mathbf{0 . 7 6}$ & $\mathbf{0 . 7 4}$ & $\mathbf{0 . 8 2}$ & $\mathbf{1 . 0 1}$ & $\mathbf{1 . 1 6}$ & $\mathbf{1 . 0 6}$ & $\mathbf{1 . 0 5}$ & $\mathbf{0 . 9 9}$ & $\mathbf{0 . 9 5}$ & $\mathbf{0 . 9 0}$ & $\mathbf{0 . 7 9}$ & $\mathbf{0 . 7 0}$ & $\mathbf{0 . 9 1}$ \\
\hline
\end{tabular}




\section{Hydrogeologic Setting}

The 24-county coastal Georgia area is underlain by coastal plain strata consisting of consolidated to unconsolidated layers of sand and clay and semiconsolidated to very dense layers of limestone and dolomite (Clarke and others, 1990). These sediments constitute three major aquifer systems, in order of descending depth: the surficial aquifer system, Brunswick aquifer system, and Floridan aquifer system (fig. 2).

In the coastal area, the surficial aquifer system (fig. 2) consists of Miocene and younger age interlayered sand, clay, and thin limestone beds (Clarke, 2003). At HAAF, the surficial aquifer consists of fine sand at depths of less than $100 \mathrm{ft}$ and largely is unconfined. Elsewhere in coastal Georgia, the aquifer system includes a water-table zone and two confined zones. The surficial aquifer system is separated from the underlying Brunswick aquifer system by a confining unit consisting of silty clay and dense, phosphatic Miocene limestone.

The Brunswick aquifer system (fig. 2) consists of two water-bearing zones - the upper Brunswick aquifer and the lower Brunswick aquifer (Clarke, 2003). The upper Brunswick aquifer consists of poorly sorted, fine to coarse, slightly phosphatic and dolomitic Miocene quartz sand and dense phosphatic limestone of the same age (Clarke and others, 1990). The lower Brunswick aquifer consists of poorly sorted, fine to coarse, phosphatic and dolomitic Oligocene and Miocene sand (Clarke and others, 1990). At HAAF, the Brunswick aquifer system consists of clayey fine sand and silt that has a much lower permeability than in the Brunswick, GA, area and can largely be considered a confining unit. Accordingly, in this study, sediments constituting the upper and lower Brunswick aquifers are considered a single unit, and the combined thickness and composite hydraulic properties are used for model simulations.

The principal source of water for all uses (excluding thermoelectric) in the coastal area is the Floridan aquifer system, which is composed of carbonate rocks of varying permeability. The Floridan aquifer system is confined by overlying clay layers and separated into several permeable water-bearing zones by layers of relatively denser limestone that act as semiconfining units allowing vertical leakage of groundwater. In the Savannah-Hilton Head Island area, McCollum and Counts (1964) identified five water-bearing zones in strata that would later be defined as part of the Floridan aquifer system.

The two shallowest of these water-bearing zones are part of the UFA, and the deeper three are part of the LFA (Krause and Randolph, 1989). In Beaufort County, SC, the term middle Floridan aquifer is used by the State of South Carolina (Ransom and White, 1999) for a water-bearing zone approximately $250-550 \mathrm{ft}$ below land surface that is equivalent to zones 3 and 4 of McCollum and Counts (1964).

The UFA is overlain by a confining unit (fig. 2) consisting of layers of silty clay and dense phosphatic Oligocene dolomite that separate the aquifer from overlying permeable units of the Brunswick aquifer system. Reported vertical

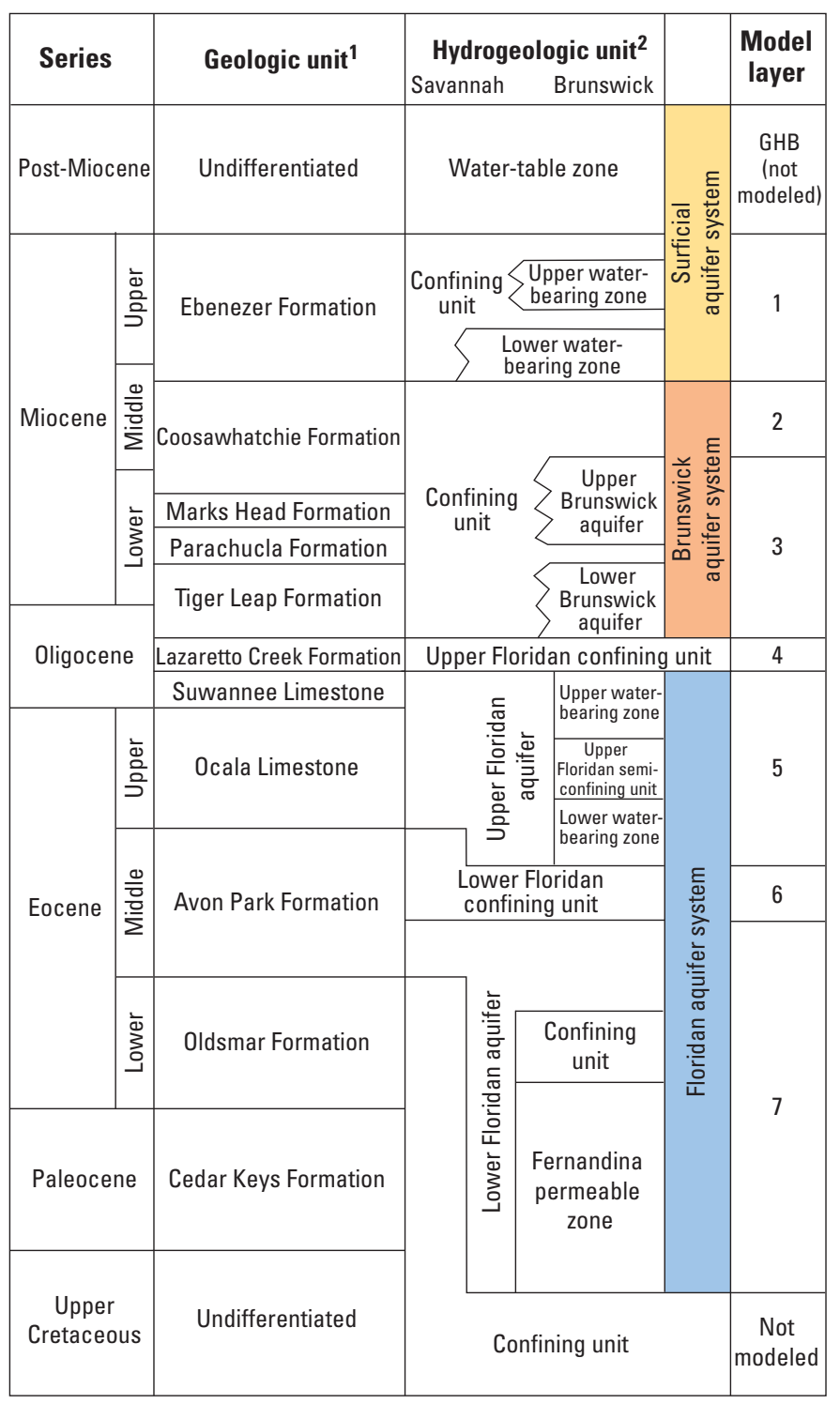

${ }^{1}$ Modified from Randolph and others, 1991; Weems and Edwards, 2001.

${ }^{2}$ Modified from Randolph and others, 1991; Clarke and Krause, 2000.

Figure 2. Generalized correlation of geologic and hydrogeologic units and model layers in the coastal plain of Georgia (modified from Payne and others, 2005). [GHB, general-head boundary]

hydraulic conductivity of this confining unit, based on laboratory analysis of core, ranges from $2.3 \times 10^{-4}$ to 3.0 feet per day (ft/d) (Clarke and others, 2004).

The UFA (fig. 2) is highly productive and consists of Eocene to Oligocene limestone and dolomite. Miller (1986) reported ranges in aquifer thickness in Chatham County from 400 to $600 \mathrm{ft}$. Reported transmissivity of the UFA in Chatham County ranges from 20,000 to 80,000 feet squared per day $\left(\mathrm{ft}^{2} / \mathrm{d}\right)$ (Clarke and others, 2004). Zones of very high hydraulic conductivity exist within relatively thin intervals of the Floridan aquifer system, especially in the UFA (Clarke and others, 2004). 
The UFA is underlain by a confining unit of dense, recrystallized limestone and dolomitic limestone of middle to upper Eocene age that hydraulically separates, to varying degrees, the UFA from the LFA (fig. 2). Counts and Donsky (1963) reported the vertical hydraulic conductivity of this confining unit was $6.7 \times 10^{-4} \mathrm{ft} / \mathrm{d}$ on the basis of laboratory analysis of a single core.

The LFA is composed of Upper Cretaceous to middle Eocene limestone and dolomitic limestone. At Savannah, the aquifer consists mostly of middle Eocene limestone, and a thickness of 100-300 ft was reported in Chatham County (Miller, 1986). Reported transmissivity of the LFA in Chatham and Bryan Counties, GA, ranged from 8,200 to $8,300 \mathrm{ft}^{2} / \mathrm{d}$ (Clarke and others, 2004).

The LFA is underlain by a confining unit consisting of Upper Cretaceous to lower Eocene marl, which Falls and others (2005) describe as a semi-indurated, fine-grained mixture of carbonate, clay, silt, and sand that generally is dominated by clay and silt. The base of the Floridan aquifer system and the underlying marl is recognized on natural-gamma logs by a sharp increase in counts per second from carbonate strata to the marl (Falls and others, 2005).

The permeability of the Floridan aquifer system is reduced in the vicinity of the Gulf Trough (fig. 3) - a zone of relatively thick accumulations of fine-grained clastic sediments and clay-bearing carbonates where the permeability of coastal plain deposits decrease. In this area, groundwater flow is partially impeded by the juxtaposition of rocks of higher permeability updip and downdip from the trough, with rocks of lower permeability within the trough (Krause and Randolph, 1989).

\section{Groundwater Flow}

Groundwater flow in the Floridan aquifer system mainly is controlled by rates and distribution of recharge to and discharge from the system, the extent and effects of confinement, and the ability of aquifers to transmit and store water (Krause and Randolph, 1989). A schematic diagram of the conceptualized predevelopment (no pumping) and modern-day (2000) flow systems in coastal Georgia is shown in figure 3. Water recharges the aquifers in the northern part of the coastal area where they are exposed at or near land surface and flows mostly southeastward toward the coast where it discharges into overlying units and surface-water bodies. Prior to development, the flow system was considered to have been at dynamic equilibrium, and potentiometric surfaces were considered nearly static from year to year.
The modern-day flow system reflects changes that have occurred as a result of groundwater development (withdrawal). Groundwater withdrawal has lowered water levels, induced additional recharge and reduced natural discharge, and degraded the quality of water in places along the coast.

An extensive cone of depression has developed in the potentiometric surface of the UFA in the Savannah area (fig. 1). HAAF lies within this regional cone of depression. Here, the principal direction of groundwater flow is toward the center of the cone of depression near Savannah.

Saltwater contamination is restricting the development of groundwater supply in coastal Georgia and adjacent parts of South Carolina and Florida (Krause and Clarke, 2001). Pumping from the UFA has resulted in substantial groundwater-level decline and subsequent saltwater intrusion from underlying strata containing highly saline water at Brunswick, GA, and encroachment of seawater at the northern end of Hilton Head Island, SC. Saltwater contamination at these locations has constrained further development of the UFA in the coastal area and has created competing demands for the limited supply of freshwater.

\section{Well and Stream Site Identification}

In this report, wells are identified by using a local site name, such as HAAF 11 and a USGS numbering system based on USGS topographic maps (such as 36Q392). In Georgia, each $7 \frac{1}{2}$-minute topographic quadrangle map has been given a number and letter designation beginning at the southwestern corner of the State. Numbers increase eastward through 39, and letters increase alphabetically northward through "Z" and then become double-letter designations "AA" through "PP." The letters "I" and "O" are not used. Wells inventoried in each quadrangle are numbered sequentially beginning with " 1. ." For example, well HAAF 8 is the 292nd well inventoried in the Garden City quadrangle (map 36Q) and is designated 36Q292.

Surface-water stations are identified by a numbering system used for hydrologic-station records in USGS publications since October 1, 1950. The order of listing stations is in a downstream direction along the main channel. All stations on a tributary entering upstream from a main stream station are listed before that station. Each surface-water station is assigned a unique 8- to 14-digit number. Each station number, such as 02352500 , begins with the 2 -digit identifier " 02 ," which designates the major river basin (for example, "02" is the South Atlantic Slope Basin), followed by the downstreamorder number, "352500," which can range from 6 to 12 digits. 


\section{A. Predevelopment}

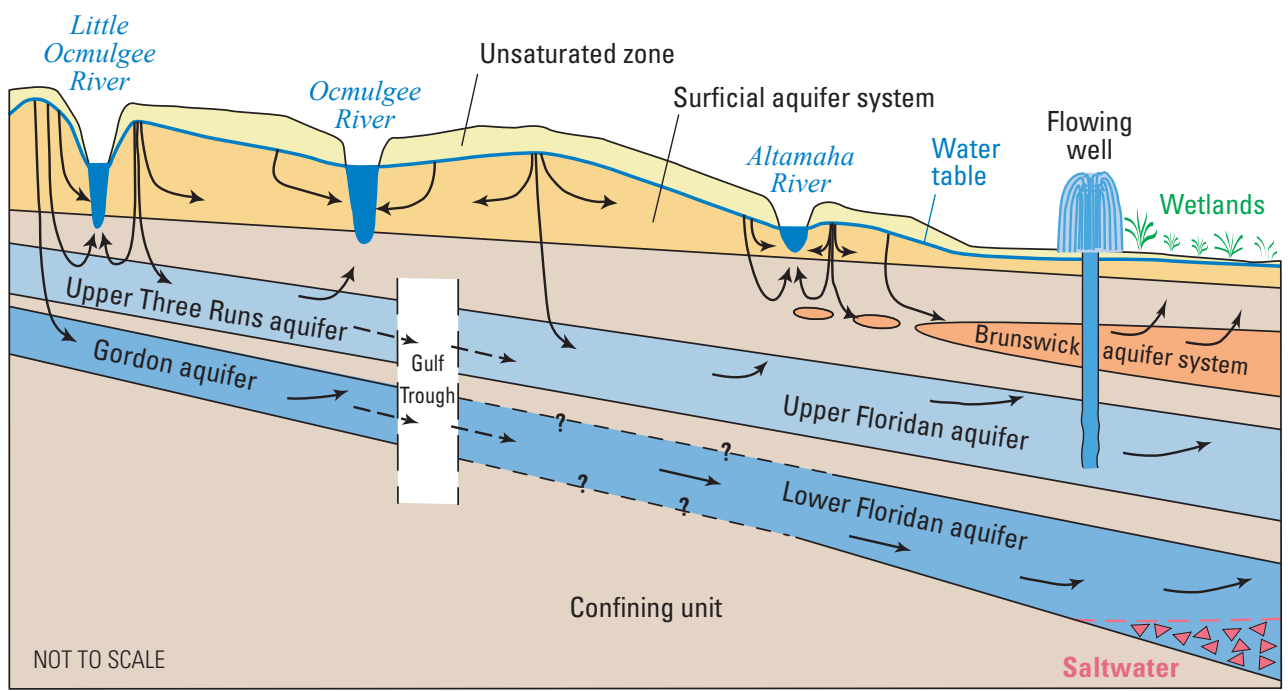

\section{B. Modern day}

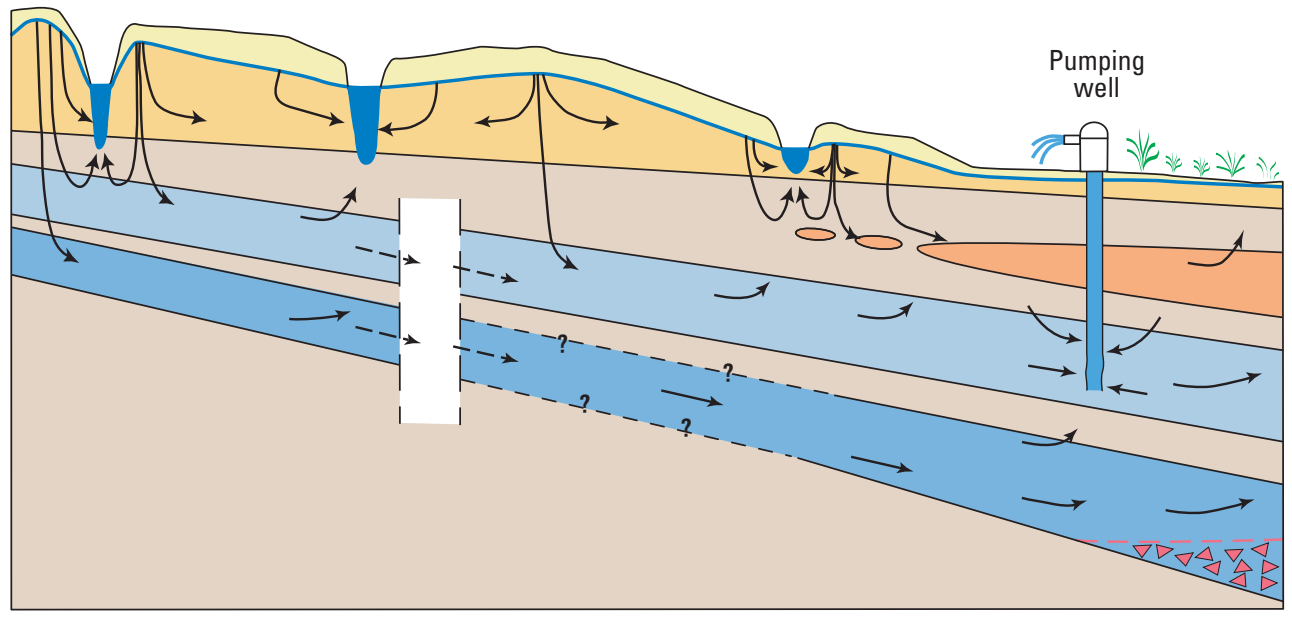

Figure 3. Schematic diagram showing conceptual model of $(A)$ predevelopment and $(B)$ modernday (2000) flow system (modified from Priest, 2004; Payne and others, 2005). 


\section{Methods of Data Collection and Analysis}

To assess the hydrogeology and water quality of the Floridan aquifer system at HAAF, site investigations were conducted during 2009, including construction of a 1,168-ft test boring and a new well (HAAF 11, 36Q392) completed in the LFA adjacent to existing HAAF Upper Floridan production well HAAF 8 (36Q292, fig. 1). Well construction and location information for all wells used during this study are listed in table 2 .

\section{Test Well Drilling}

The LFA test well (HAAF 11, 36Q392) completed for this study was drilled at HAAF during May-June 2009. Drilling was conducted in several stages to accommodate collecting core, conducting geophysical logging, and completing various hydraulic tests (table 3 ). Prior to well completion, a pilot hole was drilled using (1) hydraulic mud-rotary methods and a bentonite-based drilling fluid through unconsolidated sediments to a depth of $333 \mathrm{ft}$, and (2) reverse-air rotary methods through consolidated limestone

Table 2. Well-construction and location information for selected wells at Hunter Army Airfield and vicinity.

[NAD 83, North American Datum of 1983; NGVD 29, National Geodetic Vertical Datum of 1929; gal/min, gallon per minute; UF, Upper Floridan; LF, Lower Floridan; OW, not pumped (observation well)]

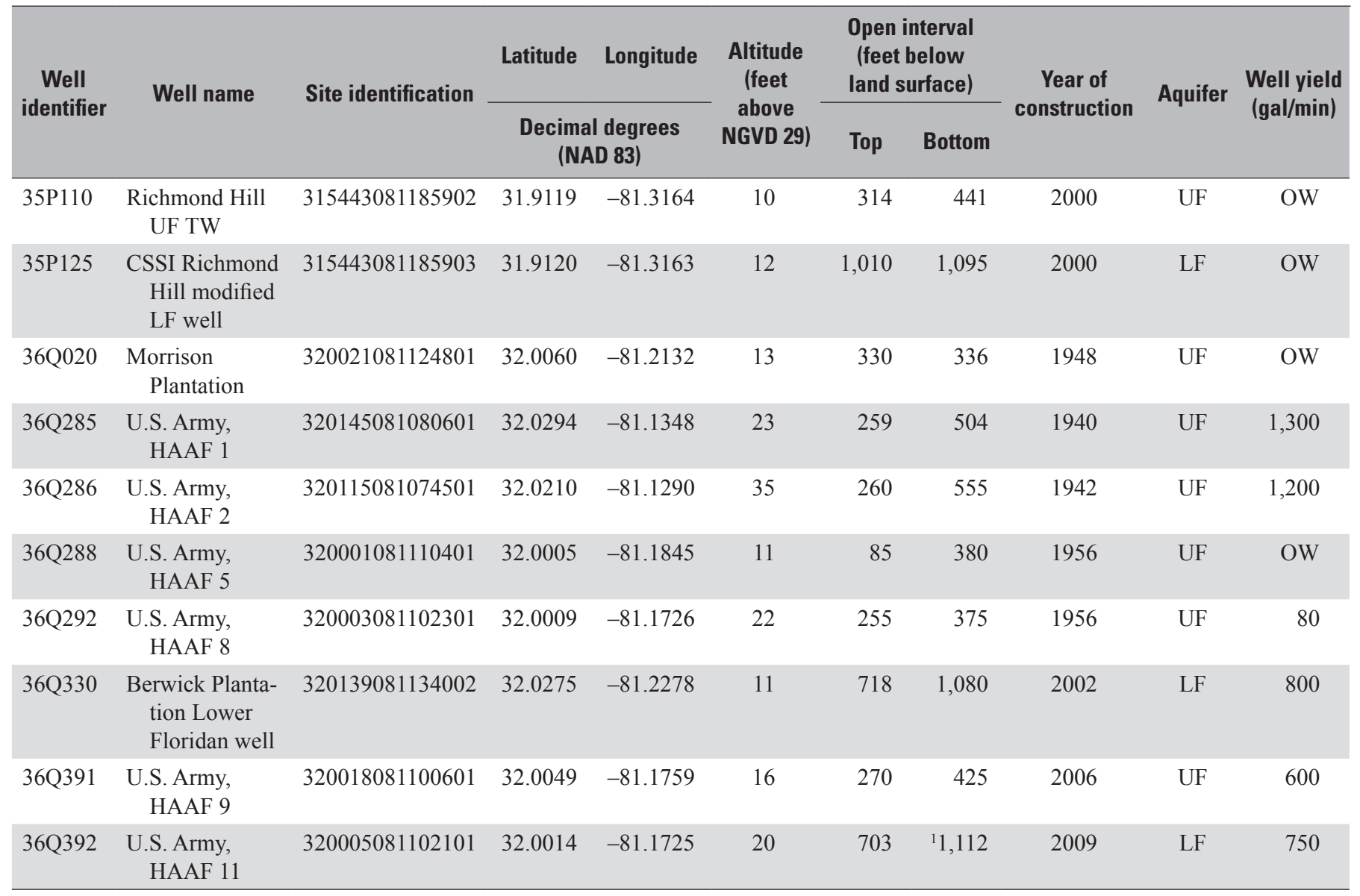

\footnotetext{
${ }^{1}$ Original borehole depth 1,168 feet; backfilled to 1,112 feet.
} 
Table 3. Chronology of drilling, logging, and testing in Lower Floridan Well HAAF 11 (360392), Hunter Army Airfield, Chatham County, Georgia, 2009.

\section{Drilling stage}

Stage 1: drilled a 32-inch hole with mud-rotary methods to 109 feet; set and grouted 24-inch casing to 86 feet

Stage 2: drilled a 23-inch hole with mud-rotary methods to 350 feet; set and grouted 16-inch casing to 333 feet

Stage 3: drilled an 8-inch pilot hole with reverse air-rotary methods to 1,168 feet; collected spot core at selected intervals during drilling

Stage 4: reamed pilot hole from 8-inch to 16 -inch to a depth of 705 feet and set and grouted 8-inch casing to 703 feet

Stage 5: cleaned out bottom part of hole from 703 to 1,112 feet
Testing/remarks

No logs collected in this interval.

Caliper and electric logs collected in mud-rotary hole prior to setting casing.

Caliper, electric, acoustic, and optical televiewer, and full-wave sonic logs collected in water-filled hole; ambient and pumping flowmeter traverses were run to determine the depth and yield of water-bearing zones and identify confining bed; packer tests completed in the confining bed.

Casing set to occlude Upper Floridan aquifer; no logs collected during this stage.

Removed cuttings from bottom part of hole for final development and well completion; ambient and pumping flowmeter traverses were run to confirm depth and yield of water-bearing zones in the completed well. of the UFA and LFA to a depth of 1,168 ft. Packer tests, ambient/pumping flowmeter traverses, and grab water samples were collected in the open borehole. These tests were critical in determining depths of the confining unit and water-bearing zones, and groundwater quality. Using this information, casing was installed to a depth of $703 \mathrm{ft}$, and the well was backfilled to a total depth of $1,112 \mathrm{ft}$, leaving an open-hole interval of 703-1,112 ft. Well-construction details are listed in table 2 and shown in figure 4 .

During drilling, rock cuttings were collected every $10 \mathrm{ft}$ from land surface to the bottom of the borehole, and changes in drill-bit penetration rates and the specific conductance of drilling fluids were monitored and recorded. Reflected-light microscopy was used to describe the mineralogy and texture of rock cuttings. Changes in drill-bit penetration rates were compared to lithologic changes observed in cuttings to assist in determining the depth intervals of contacts between rock units and voids, including solution cavities in the subsurface. A generalized description of rock cuttings is provided in table 4.

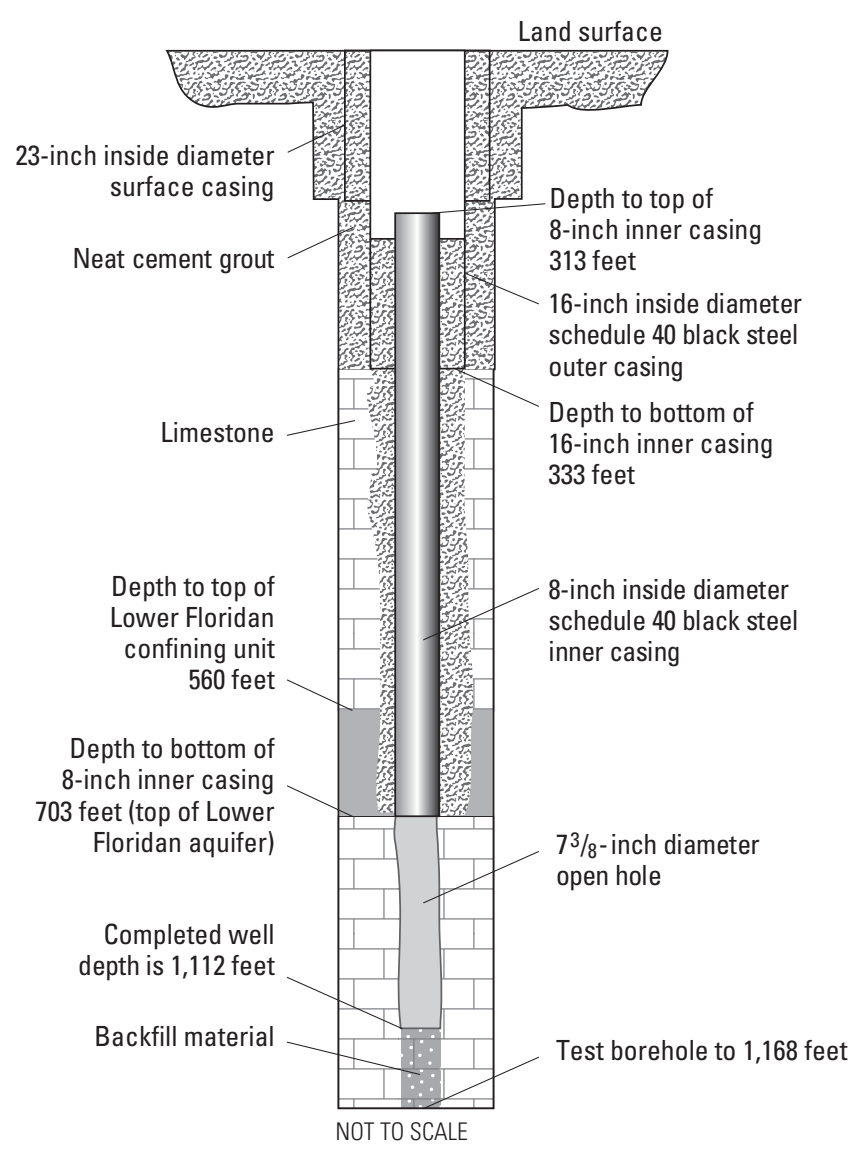

Figure 4. Well-construction diagram for well HAAF 11 (360392) completed in the Lower Floridan aquifer, Hunter Army Airfield, Chatham County, Georgia, 2009. 
Table 4. Lithologic description of rock cuttings, well HAAF 11 (360392), Hunter Army Airfield, Chatham County, Georgia.

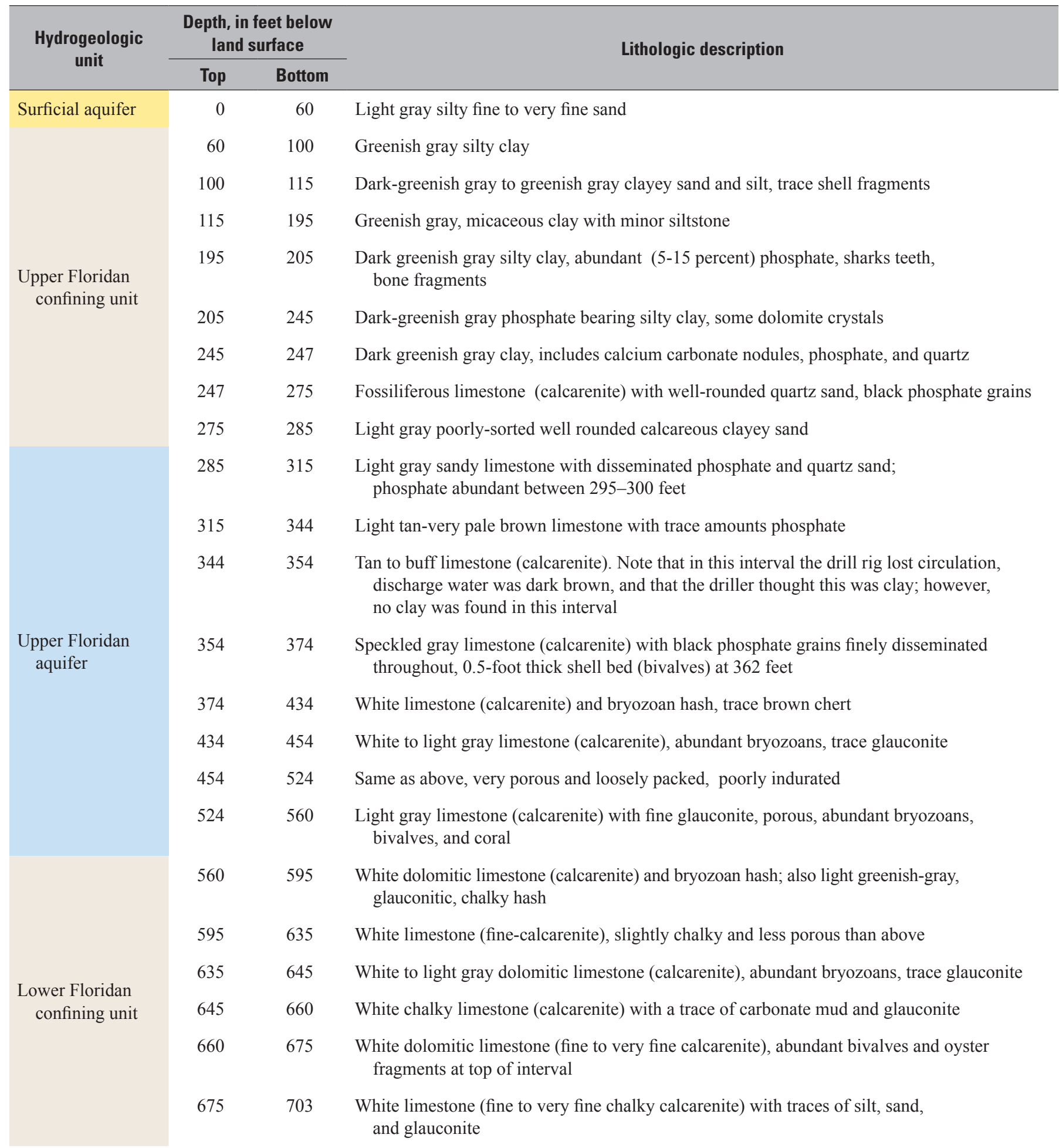


Table 4. Lithologic description of rock cuttings, well HAAF 11 (360392), Hunter Army Airfield, Chatham County, Georgia.-Continued

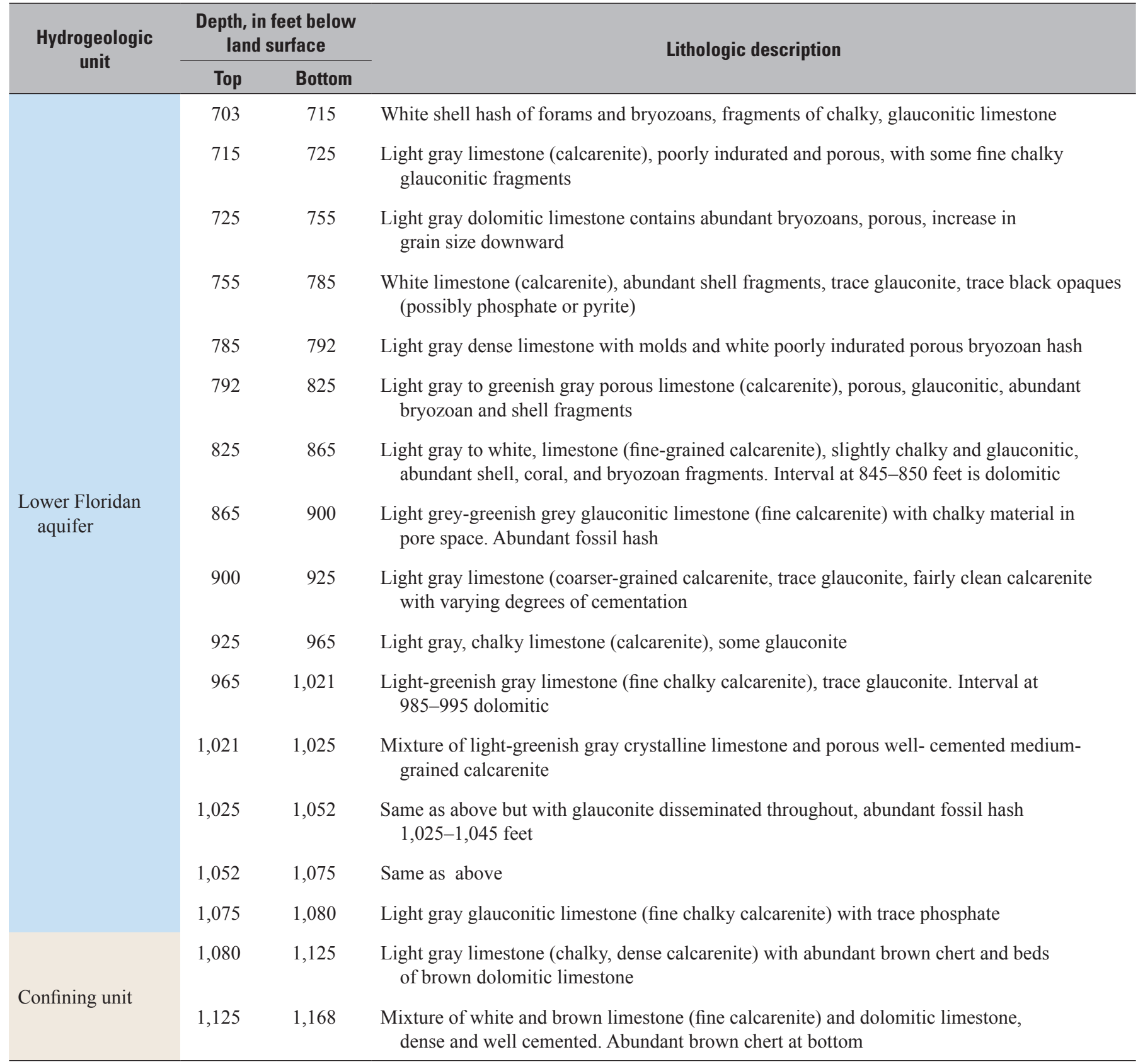




\section{Borehole Geophysical Logs}

Borehole geophysical logs were collected at various stages of drilling to characterize the physical properties of sediments penetrated. The first set of logs was collected in the $0-333 \mathrm{ft}$ interval, where mud-rotary drilling was used to penetrate Miocene and younger clastic sediments. The second set of logs was collected in the 333-1,168 ft interval, following installation of 16 -inch casing to a depth of $333 \mathrm{ft}$.
Borehole geophysical logs include caliper; natural gamma; spontaneous potential; single-point, lateral, long- and shortnormal resistivity; borehole fluid resistivity and temperature; full-waveform sonic; acoustic televiewer (not shown in this report); and optical televiewer. Selected borehole geophysical data from well HAAF 11 (36Q392) are shown in figure 5.

A variety of geophysical logs were used to indicate the locations of permeable zones in the hydrogeologic units.

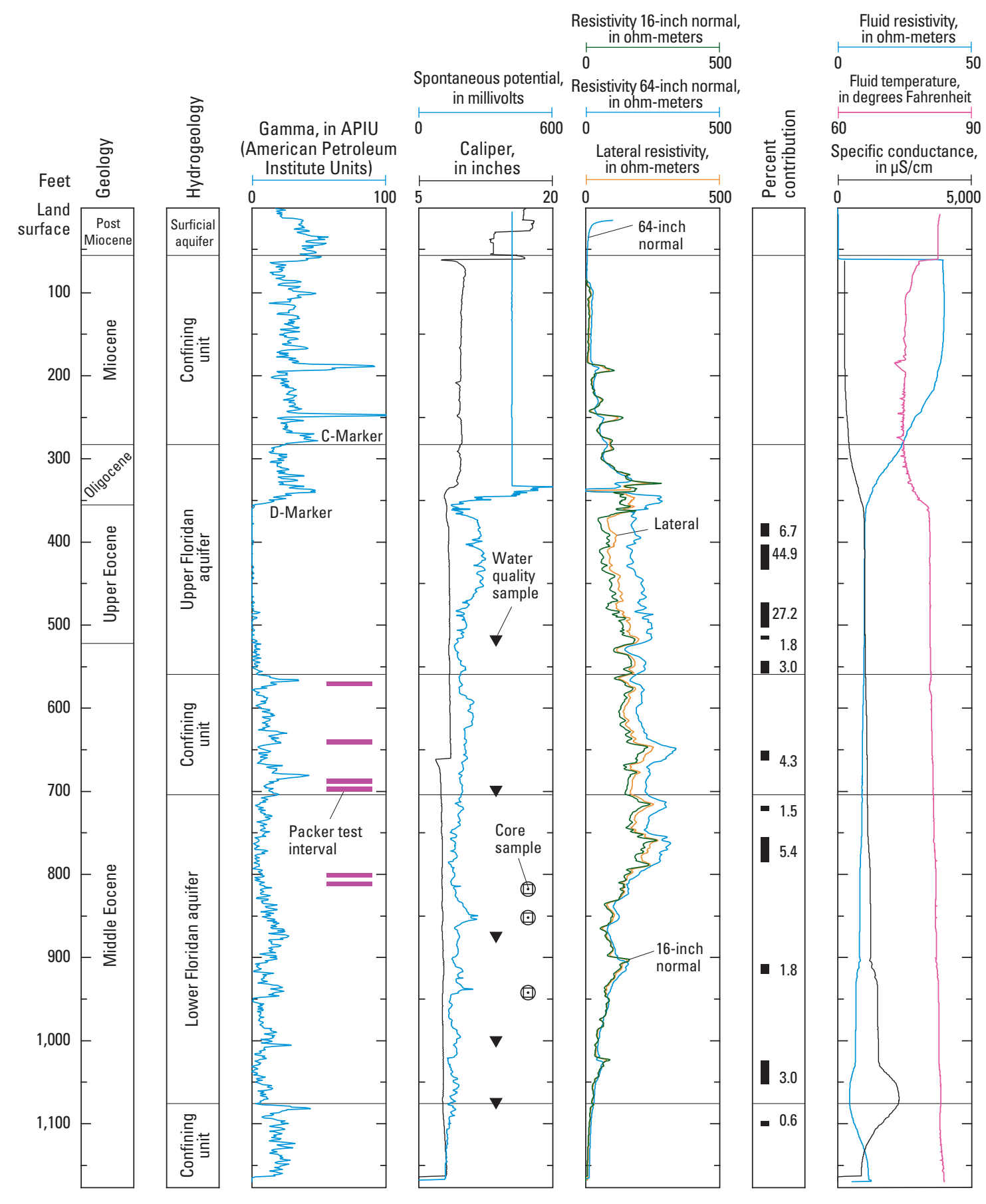

Figure 5. Selected borehole geophysical data from well HAAF 11 (360392). Percentage flow contribution determined from flowmeter survey in open borehole, 333-1,168 feet (see figure 6A), Hunter Army Airfield, Chatham County, Georgia (modified from Williams, 2010). [ $\mu \mathrm{S} / \mathrm{cm}$, microsiemens per centimeter at 25 degrees Celsius] 
Sharp increases on formation resistivity logs (single-point, lateral, and long- and short- normal resistivity) were observed and often corresponded to locations of water-bearing intervals that were later identified through flowmeter testing. Additional information on the locations of water-bearing intervals was provided by optical televiewer and full-waveform sonic (variable density) logs. The optical televiewer provides a photographic snapshot inside the borehole, enabling visual identification of solution openings and less permeable intervals in the rock units. The full-waveform sonic log provides an indication of the relative velocity of soundwaves traveling through bedrock. In general, when travel times are relatively rapid, bedrock is denser; when travel times are relatively slow, more voids are present. Zones of secondary permeability shown in figure 5 were derived by examining images from the optical televiewer and full-waveform sonic log.

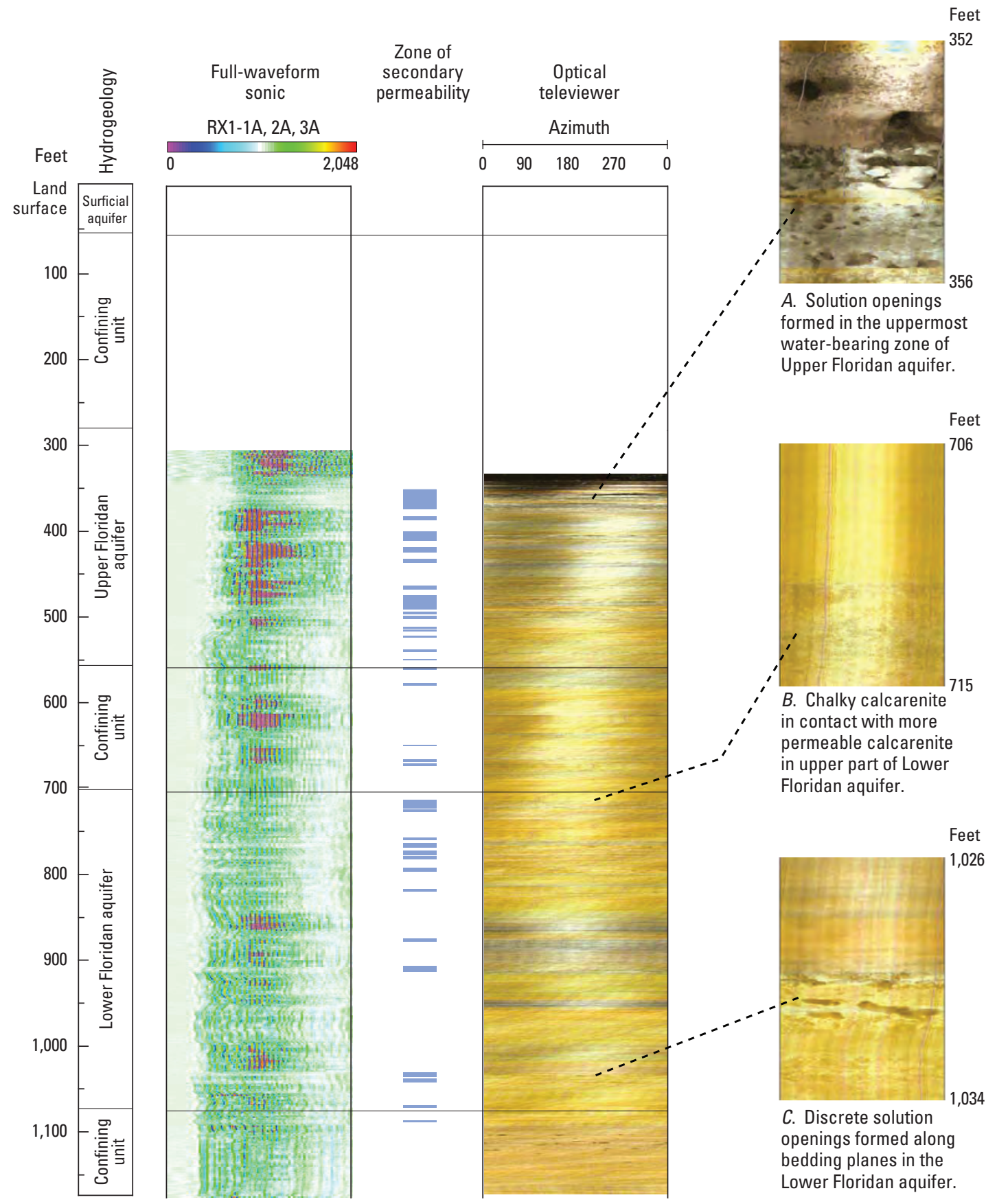

Figure 5. Selected borehole geophysical data from well HAAF 11 (360392). Percentage flow contribution determined from flowmeter survey in open borehole, 333-1,168 feet (see figure 6A), Hunter Army Airfield, Chatham County, Georgia (modified from Williams, 2010). [uS/cm, microsiemens per centimeter at 25 degrees Celsius]—Continued 


\section{Flowmeter Testing}

Flowmeter testing provided valuable insight regarding the relative contribution of flow from water-bearing zones in the UFA and LFA and confinement between the two aquifers (fig. 6A, B). This information ensured accurate placement of well casing in the completed well. Tests were conducted in two stages-(1) June 17, 2009, upon completion of drilling to a total depth of $1,168 \mathrm{ft}$ and prior to installation of the 8-inch casing to test flow in the 333-1,168 ft interval (UFA and LFA, fig. 6A), and (2) August 15, 2009, after installation of the 8-inch casing to test flow in the 703-1,112 ft interval (LFA only, fig. $6 B$ ). The first stage included assessment of borehole flow, pumping at a rate of 847 gallons per minute (gal $/ \mathrm{min})$, during the second stage borehole flow was measured at a rate of $748 \mathrm{gal} / \mathrm{min}$. Testing was conducted by installing a test pump in the well and pumping while several traverses were made in the open borehole with an electromagnetic (EM) flowmeter to measure accumulated flow up the borehole (fig. 6A, $B$ ).
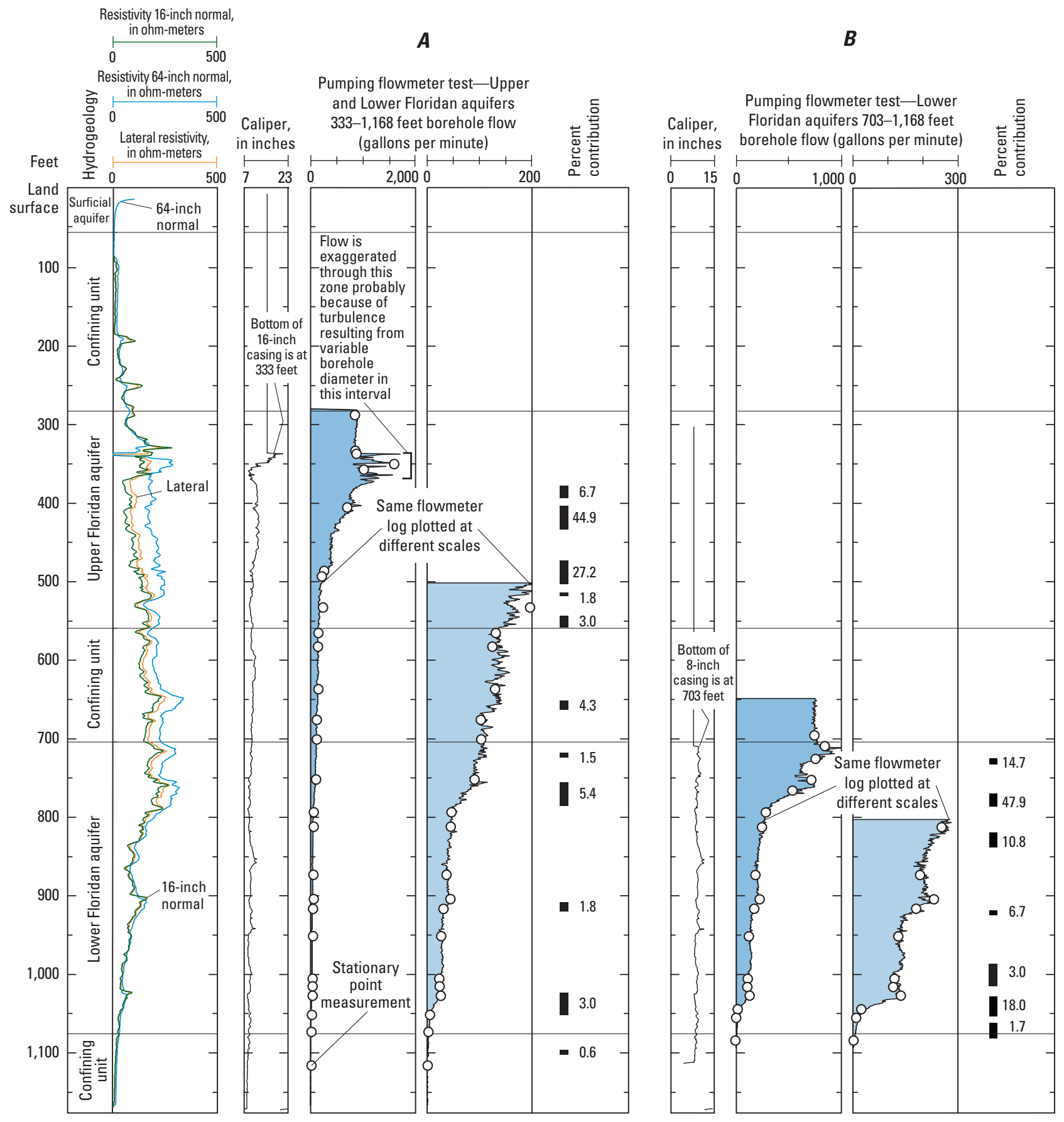

Figure 6. Borehole flowmeter data from well HAAF 11 (360392), Hunter Army Airfield, Chatham County, Georgia: (A) pumping flowmeter survey of the Upper and Lower Floridan aquifers completed on June 17, 2009, prior to installation of casing; and (B) pumping flowmeter survey of the Lower Floridan aquifer completed on August 15, 2009, after installation of casing (modified from Williams, 2010). 


\section{Water-Quality Sampling and Analysis}

To assess vertical distribution of water quality, specific conductance of discharge water was monitored with a calibrated water-quality meter as reverse air drilling of the pilot hole progressed. After drilling the length of each $20-\mathrm{ft}$ section of drill pipe, water samples were collected and specific conductance was measured (fig. 7). The pilot hole was terminated at a depth of $1,168 \mathrm{ft}$ because a sharp rise in the specific conductance of drilling fluids to about 1,063 microsiemens per centimeter $(\mu \mathrm{S} / \mathrm{cm})$ at about $1,055 \mathrm{ft}$ indicated that water quality had degraded from fresh to brackish.

During borehole flowmeter testing, a wireline water sampler was used to collect water samples at five separate intervals in the open borehole (table 5; fig. 8). These samples represent a composite of water entering the borehole beneath that depth. For example, the sample at $1,000 \mathrm{ft}$ represents a composite of water entering the borehole between $1,000 \mathrm{ft}$ and the total depth of the borehole, $1,168 \mathrm{ft}$. Water samples were removed from the wireline sampler as it emerged from the borehole using a peristaltic pump to transfer the water into sample bottles.

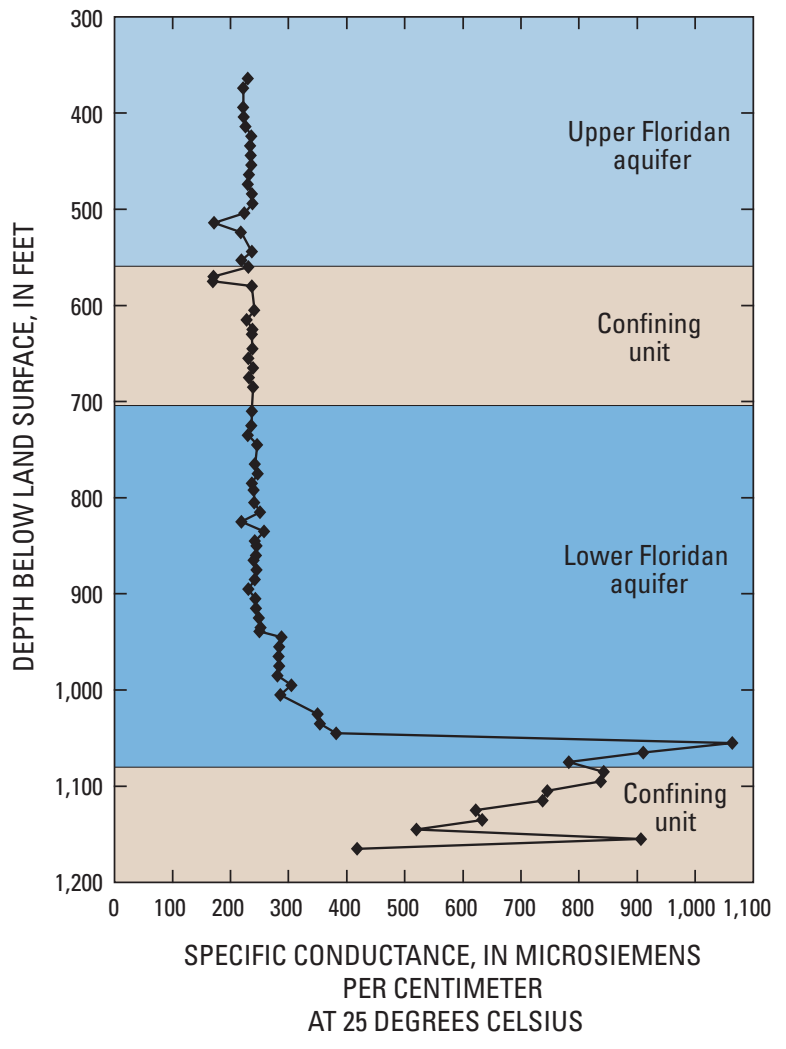

Figure 7. Specific conductance of drilling fluids while drilling well HAAF 11 (360392), Hunter Army Airfield, Chatham County, Georgia, 2009.

Upon completion of well construction, a water sample was collected and analyzed from the completed (703-1,112 ft) well near the end of the 72-hour aquifer test. Samples were analyzed for major ions, including chloride and sulfate, and for alkalinity as calcium carbonate, an indicator of hardness. Water samples for ion analysis were filtered using 0.45 -micrometer capsule filters and analyzed at Test America Laboratories, Savannah, GA. Water-quality analyses are summarized in table 5 and figure 8. A trilinear diagram showing the relative composition of major ions in water from the various depth intervals is shown in figure 9. In general, constituent concentrations increase with depth of sampled interval.
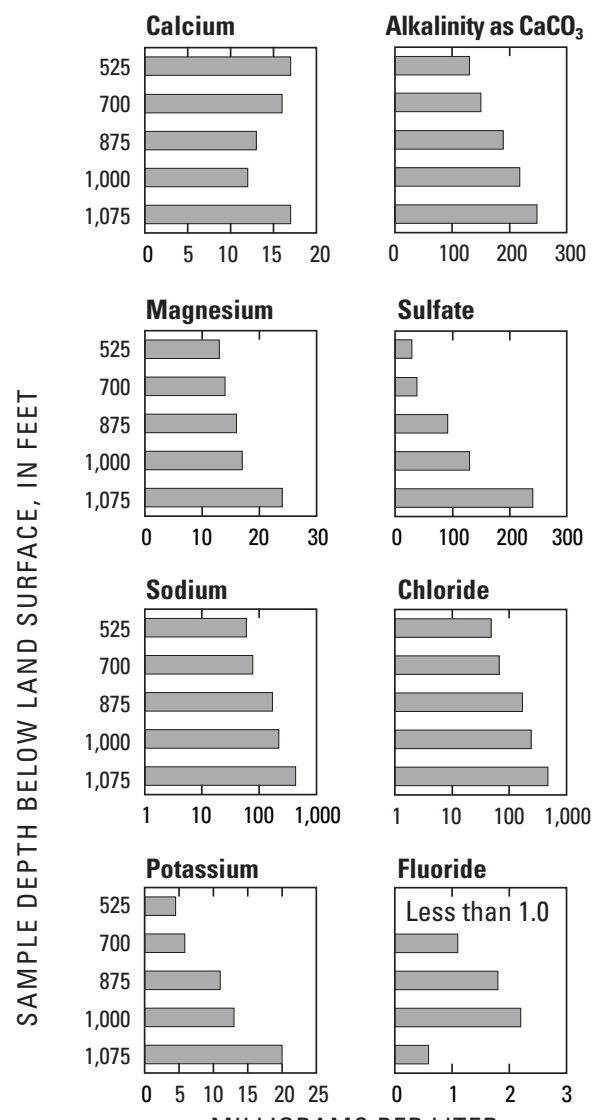

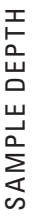




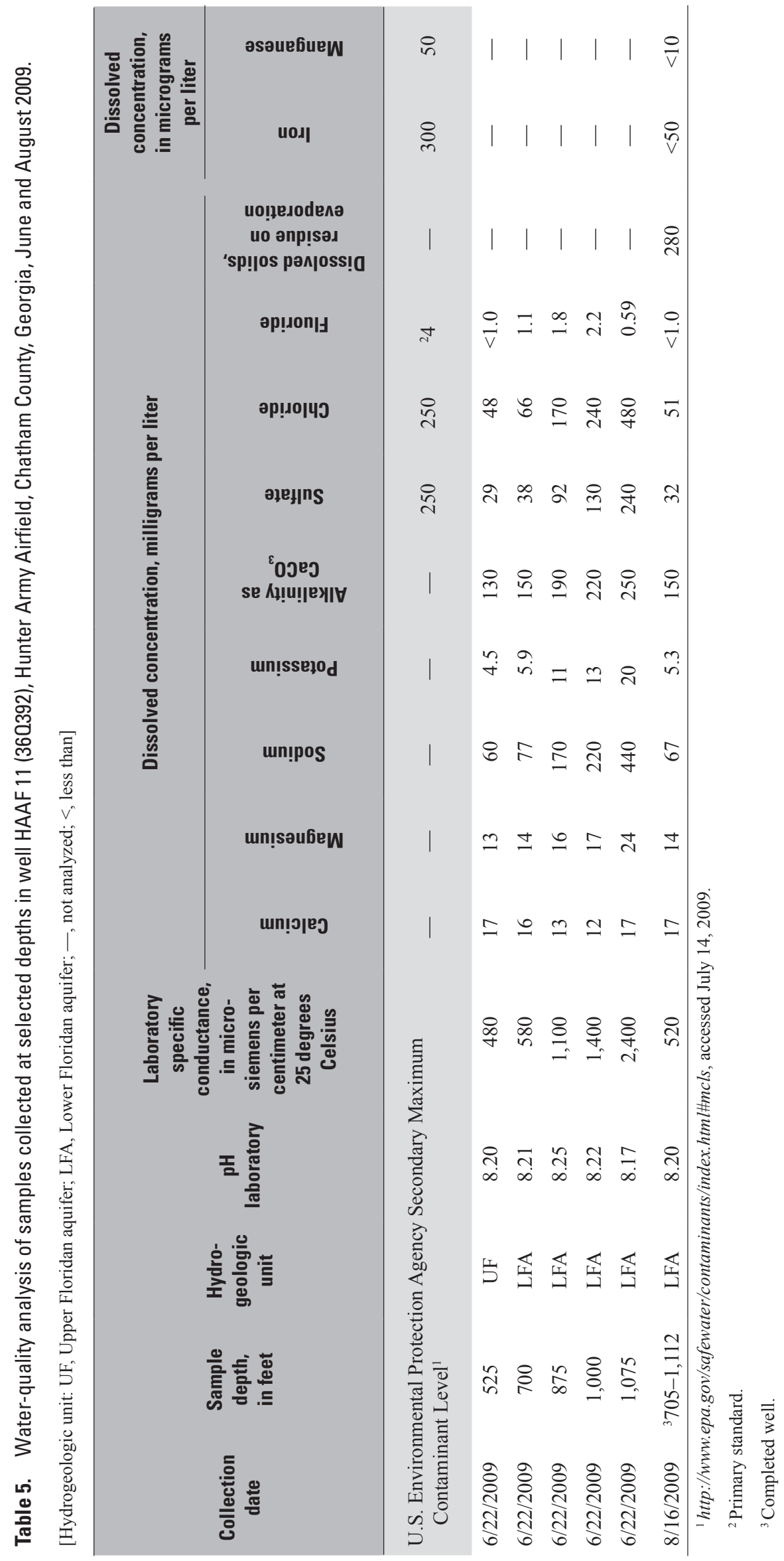




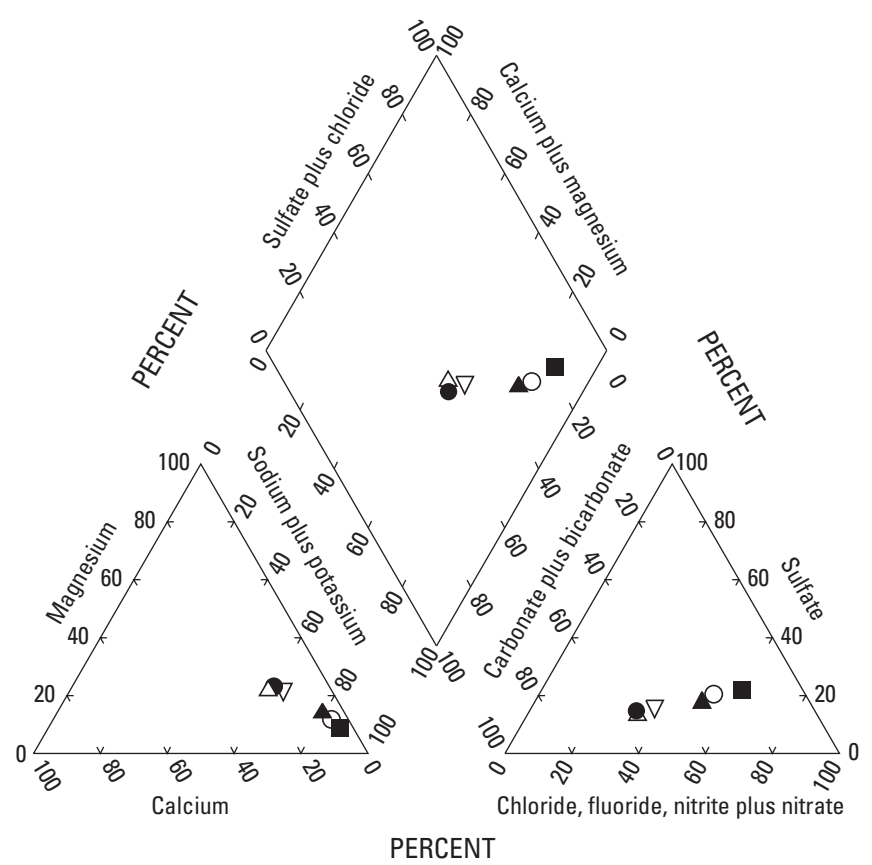

EXPLANATION

Sampling depth, in feet

$\begin{array}{ccc}\triangle 525 & \Delta 875 & \square 1,075 \\ \nabla 700 & \bigcirc 1,000 & \bullet \begin{array}{c}\text { Completed well } \\ (703-1,112 \text { feet })\end{array}\end{array}$

Figure 9. Trilinear diagram showing composition of major ions at various depths at well HAAF 11 (360392), Hunter Army Airfield, Chatham County, Georgia, July 2009. [Percentages are based on milliequivalents per liter]

\section{Core Hydraulic Analysis and Packer-Slug Tests}

To evaluate the hydraulic conductivity of the LFA, core samples were collected and analyzed for vertical hydraulic properties at a testing laboratory, and packer-slug tests were conducted in the borehole for horizontal hydraulic properties. Samples were collected at depths of 817.8-818.4; 851.8-852.2; and 941.9-942.6 ft and submitted to S\&ME Inc., Savannah, GA, for hydraulic testing of vertical hydraulic conductivity $\left(\mathrm{K}_{\mathrm{v}}\right)$ and porosity (table 6$)$. These largely consolidated core samples were preserved onsite using procedures described in ASTM D5079 and analyzed using a flexible wall permeameter following procedures described in ASTM D5084.

Additional information on the hydraulic conductivity of hydrogeologic units was obtained by conducting packerslug tests at selected intervals: 571-575, 641-645, 688-692, 698-702, 802-806, and 812-816 ft (table 7). A description of the techniques used to deploy and test the integrity of the packer system is provided in Holloway and Waddell (2008). Each of the test intervals was isolated using straddle packers, and a slug of water was injected into the interval and the rate of head decline was recorded. Data were analyzed for horizontal hydraulic conductivity $\left(\mathrm{K}_{\mathrm{h}}\right)$ using the Bouwer and Rice (1976) method. The Bouwer and Rice (1976) method assumes that the aquifer has an infinite areal extent, is homogeneous with a uniform thickness, the test well is fully or partially penetrating, effects of storage are negligible, flow to the well is quasi-steady-state, and the slug is introduced into the well instantaneously.

\section{Aquifer Tests}

Aquifer tests were conducted in an existing UFA well (HAAF 9, 36Q391) and in the newly constructed LFA well (HAAF 11, 36Q392) to determine hydraulic properties of the aquifers and whether pumping the LFA well produced a drawdown response in the UFA. Details on these tests are provided in Williams (2010); a brief description is provided here and in subsequent sections; results are summarized in table 8 .

Table 6. Vertical hydraulic conductivity and porosity of core samples collected from the Lower Floridan aquifer at well HAAF 11 (360392), Hunter Army Airfield, Chatham County, Georgia.

[Analyses by S\&ME, Inc., Savannah, Georgia]

\begin{tabular}{ccc}
\hline $\begin{array}{c}\text { Interval } \\
\text { (feet below } \\
\text { land surface) }\end{array}$ & $\begin{array}{c}\text { Vertical hydraulic } \\
\text { conductivity } \\
\text { (feet per day) }\end{array}$ & $\begin{array}{c}\text { Porosity } \\
\text { (percent) }\end{array}$ \\
\hline $817.8-818.4$ & 0.20 & 36.6 \\
$851.8-852.2$ & 0.13 & 44.1 \\
$941.9-942.6$ & 0.34 & 51.8 \\
\hline
\end{tabular}

Table 7. Horizontal hydraulic conductivity determined from packer-slug tests at well HAAF 11 (360392), Hunter Army Airfield, Chatham County, Georgia (modified from Williams, 2010).

\begin{tabular}{cccc}
\hline $\begin{array}{c}\text { Hydrogeologic } \\
\text { unit }\end{array}$ & $\begin{array}{c}\text { Interval, } \\
\text { in feet below } \\
\text { land surface }\end{array}$ & $\begin{array}{c}\text { Horizontal } \\
\text { hydraulic } \\
\text { conductivity, } \\
\text { in feet } \\
\text { per day }\end{array}$ & $\begin{array}{c}\text { Estimated } \\
\text { vertical } \\
\text { hydraulic } \\
\text { conductivity, } \\
\text { in feet } \\
\text { per day }\end{array}$ \\
\hline $\begin{array}{c}\text { Lower Floridan } \\
\text { confining unit }\end{array}$ & $571-575$ & 1.1 & 0.13 \\
& $641-645$ & 3.1 & 0.36 \\
\hline $688-692$ & 0.16 & 0.02 \\
Lower Floridan & $802-806$ & 0.20 & 0.02 \\
aquifer & $812-816$ & 1.7 & 0.19 \\
\hline
\end{tabular}

${ }^{1}$ Estimated using Bouwer and Rice (1976) method.

${ }^{2}$ Estimated on the basis of the ratio of horizontal to vertical hydraulic conductivity of core from 817.8- to 818.4-foot interval (table 6) and packer test from 812- to 816-foot interval. 
Table 8. Summary of aquifer tests conducted in Upper and Lower Floridan aquifer wells at Hunter Army Airfield, Chatham County, Georgia, 2009.

\begin{tabular}{|c|c|c|c|c|c|c|c|c|}
\hline $\begin{array}{c}\text { Pumping } \\
\text { well }\end{array}$ & $\begin{array}{c}\text { Observation } \\
\text { well }\end{array}$ & $\begin{array}{c}\text { Hydrologic } \\
\text { unit }\end{array}$ & $\begin{array}{l}\text { Testing } \\
\text { period }\end{array}$ & $\begin{array}{c}\text { Test } \\
\text { duration } \\
\text { (hours) }\end{array}$ & $\begin{array}{l}\text { Average } \\
\text { pumping } \\
\text { rate in } \\
\text { gallons } \\
\text { per minute }\end{array}$ & $\begin{array}{l}\text { Transmissivity, } \\
\text { in feet } \\
\text { squared } \\
\text { per day }\end{array}$ & Storage & Remarks \\
\hline $\begin{array}{l}\text { HAAF } 9 \\
\quad(36 Q 391)\end{array}$ & $\begin{array}{l}\text { HAAF } 8 \\
\quad(36 Q 292)\end{array}$ & $\begin{array}{l}\text { Upper } \\
\text { Floridan }\end{array}$ & $\begin{array}{c}\text { February } \\
17-18 \\
2009\end{array}$ & 24 & 430 & 39,700 & $2.54 \times 10^{-04}$ & $\begin{array}{l}\text { Computed using Hantush } \\
\text { (1960) leaky aquifer } \\
\text { solution. Drawdown was } \\
\text { corrected for tidal and other } \\
\text { fluctuations prior to analysis. }\end{array}$ \\
\hline $\begin{array}{l}\text { HAAF } 11 \\
\qquad(36 Q 392)\end{array}$ & - & $\begin{array}{l}\text { Lower } \\
\text { Floridan }\end{array}$ & $\begin{array}{c}\text { August } \\
13-16, \\
2009\end{array}$ & 72 & 748 & $\begin{array}{c}10,700 \\
\text { (drawdown), } \\
12,100 \\
\text { (recovery) }\end{array}$ & - & $\begin{array}{l}\text { Single well test conducted } \\
\text { upon completion of Lower } \\
\text { Floridan well open from } \\
703 \text { to } 1,112 \text { feet. Analysis } \\
\text { used Theis (1935) solution. } \\
\text { Drawdown was corrected for } \\
\text { tidal and other fluctuations } \\
\text { prior to analysis. Drawdown } \\
\text { also monitored in Upper } \\
\text { Floridan wells HAAF } 5 \text { and } \\
\text { HAAF } 8 \text { to assess inter- } \\
\text { aquifer leakage response. }\end{array}$ \\
\hline
\end{tabular}

To determine transmissivity of the UFA, a 24-hour aquifer test was conducted February 17-18, 2009. For this test, well HAAF 9 (36Q391) was pumped at an average rate of $430 \mathrm{gal} / \mathrm{min}$, and drawdown response was observed in the pumped well and in well HAAF 8 (36Q292), located about $2,020 \mathrm{ft}$ to the southwest (table 2; fig. 1). A similar 72-hour test was conducted August 13-16, 2009, in well HAAF 11 (36Q392) to determine the transmissivity of the LFA. For this test, well HAAF 11 (36Q392) was pumped at an average rate of $748 \mathrm{gal} / \mathrm{min}$, and water levels were recorded in the pumped well and in two observation wells (wells HAAF 5 and HAAF 8), completed in the UFA, to assess interaquifer leakage response. For each test, data were collected and analyzed using the following procedures:

- Prior, during, and after each aquifer test, water levels were monitored to determine static water levels and assess ambient water-level fluctuations and trends.

- Upon completion of the pumping period, water-level recovery was monitored for a minimum period equal in length to the pumping period.
- Test data were corrected to remove tidal and barometric fluctuations and influence of regional pumping trends.

Aquifer test drawdown data were evaluated for local hydraulic properties using analytical solutions (Williams, 2010).

\section{Groundwater-Flow Model}

A groundwater-flow model previously developed by the USGS (Payne and others, 2005) was modified for finer spatial resolution and site-specific data to assess (1) the amount of induced interaquifer leakage and drawdown in the UFA resulting from pumping the LFA at a rate of $748 \mathrm{gal} / \mathrm{min}$, and (2) the equivalent amount of pumpage from the UFA that would replicate simulated drawdown in the UFA (that resulted from pumping the LFA) at two alternate locations (A) adjacent to the newly constructed LFA well and (B) at a distance of $3,600 \mathrm{ft}$ from the new well. The revised model also was used to simulate groundwater-pumping scenarios evaluating the effect of various pumping redistributions on groundwater conditions at HAAF. Modifications to the groundwater model are described in the appendix. 


\section{Hydrogeology and Water Quality of the Floridan Aquifer System}

Miller (1986) provided a regional definition of the Floridan aquifer system on the basis of stratigraphic and borehole geophysical data that were widely spaced over the coastal area of Georgia and South Carolina. New hydrogeologic and water-quality data were used as a basis to refine the definition of the Floridan aquifer system at HAAF. Initial estimates of the depth and thickness of units constituting the Floridan aquifer system were obtained using Miller's (1986) structural contour maps. These maps indicated that the Floridan aquifer system at HAAF was approximately 760 -ft thick, with the UFA between altitudes of $-240 \mathrm{ft}$ and $-790 \mathrm{ft}$ (NGVD 29) and the LFA between altitudes of -930 and -1,000 (NGVD 29). Given a land surface altitude of $20 \mathrm{ft}$ (NGVD 29) at the HAAF drilling site, Miller's (1986) projected depths below land surface to the UFA were 260 to $810 \mathrm{ft}$, and to the LFA were 950 to $1020 \mathrm{ft}$. Subsequently, these depths were adjusted based on data collected from the newly constructed HAAF test well (HAAF 11, 36Q392).

In general, hydrogeologic units of the Floridan aquifer system can be distinguished by differences in flow contribution, lithology, geophysical signatures, and water quality. The following sections describe the depths, hydraulic properties, and water quality of hydrogeologic units that constitute the Floridan aquifer system at HAAF.

\section{Upper Floridan Aquifer}

The UFA at well HAAF 11 (36Q392) is present between depths of 285 and $560 \mathrm{ft}$ and includes several high permeability zones in limestone (table 4; fig. 5). The top of the aquifer is composed of the Oligocene Suwannee Limestone and corresponds to a spike in the natural-gamma log called the "C-marker" (Wait, 1965; Gregg and Zimmerman, 1974; Clarke and others, 1990). The thickest part of the aquifer is composed of upper Eocene Ocala Limestone, which is characterized by a very low natural-gamma level, the top of which is called the "D-marker" (Wait, 1965; Gregg and Zimmerman, 1974; Clarke and others, 1990). The base of the aquifer $(560 \mathrm{ft})$ is present in the uppermost part of middle Eocene limestone (Avon Park Formation) and was designated on the basis of flowmeter data that indicated a large reduction in borehole flow at that depth.

At well HAAF 11, the uppermost part of the UFA at 285-333 ft was isolated by well casing and not evaluated during flowmeter testing. Interpretation of borehole flowmeter data for June 17, 2009, indicates five main water-bearing intervals at the HAAF 11 (36Q392) well site: 380-395, 405-435, 475-505, 515-520, and 545-560 ft (fig. 6A). These intervals seem to coincide with the development of secondary permeability in the aquifer in the form of solution cavities and voids that have a higher permeability than the native-rock matrix. Formation-resistivity logs indicate that each of these water-bearing intervals coincides with an increase in resistivity (fig. 5). Solution openings in the uppermost part of the UFA are evident for the 352-356 ft interval as shown on the optical televiewer $\log$ (fig. 5). Flowmeter data indicated that when pumping at a rate of $847 \mathrm{gal} / \mathrm{min}, 83.5$ percent of the total flow came from the UFA, and the remaining 16.5 percent of the total flow came from the underlying confining unit and the LFA.

Water-bearing intervals of 405-435 ft and 475-505 ft in the UFA produced the highest percentage of accumulated flow with an estimated $610 \mathrm{gal} / \mathrm{min}$ or 72 percent of the total pumpage. The remaining three zones in the UFA produced a combined flow of $97 \mathrm{gal} / \mathrm{min}$ or 11.5 percent of the total pumpage. The base of the UFA, which is the top of the Lower Floridan confining unit, was designated at a depth of $560 \mathrm{ft}$, where a contribution to borehole flow was not detected.

Water from the UFA can be distinguished from that of the LFA by lower specific conductance and concentrations of dissolved constituents, and by differences in the relative percentage of constituents (water type). Monitoring of reverse-air drilling fluids (formation water) indicates that water from the UFA, compared to deeper units, is relatively low in dissolved solids as indicated by lower specific conductance values, averaging $226 \mu \mathrm{S} / \mathrm{cm}$ (fig. 7). During flowmeter testing on June 22, 2009, a water-quality sample was collected using a wireline sampler in the open borehole from the UFA at a depth of $525 \mathrm{ft}$ and analyzed for major ions (table 5; figs. 8, 9). Water from this interval represents a composite sample collected between $525 \mathrm{ft}$ and the bottom of the borehole at 1,168 ft. Because of the relatively higher percentage flow contribution from the UFA, this sample is mostly representative of water from the UFA. Water from this sample is hard with an alkalinity value of 150 milligrams per liter $(\mathrm{mg} / \mathrm{L})$ and contains low concentrations of chloride $(48 \mathrm{mg} / \mathrm{L})$ and sulfate $(29 \mathrm{mg} / \mathrm{L})$. Each constituent analyzed was within U.S. Environmental Protection Agency (USEPA) primary maximum contaminant levels (MCL) and secondary maximum contaminant levels (SMCL; U.S. Environmental Protection Agency, 2009). Water from the UFA appears to be a slightly sodium-dominated mixed-anion type (fig. 9), whereas water from the LFA transitions to a sodium-chloride type in deeper parts of the aquifer.

To determine the transmissivity of the UFA, a 24-hour aquifer test was conducted February 17-18, 2009. For this test, well HAAF 9 (36Q291) was pumped at an average rate of $430 \mathrm{gal} / \mathrm{min}$, drawdown response was observed in the pumped well and in well HAAF 8 (36Q292), which is located about 2,020 ft to the southwest (table 1; fig. 1).

A well completed in the UFA at Morrison Plantation (36Q020), approximately 2.41 miles (mi) west of well HAAF 9 (36Q291), was selected as a suitable background monitoring point for filtering unwanted water-level fluctuations from aquifer-test data. The background well shows similar regional 
trends to wells HAAF 8 (36Q292) and HAAF 9 (36Q291) and is influenced by tidal fluctuations. The well is located far enough away from well HAAF 9 (36Q291) not to be affected by pumping during the 24 -hour aquifer test (fig. 10). Widerfrequency fluctuations seen on the hydrographs were attributed to barometric pressure changes during the 24-hour test period.

The amplitude and phase of each time series dataset (background, tide, barometric pressure) were adjusted to create a composite synthetic water-level hydrograph that would span the period of the test (fig. 11) using the method presented in Halford (2006). Adjustments to these individual time series components were made to minimize differences between synthetic and measured water levels (residuals). Estimated pumping induced drawdown was derived from the residuals during pumping and recovery periods. Visual examination and the root mean square (RMS) error of computed residuals were used to evaluate the effectiveness of each stage of filtering. The closer a value is to 0 , the more representative the estimated value.

A trial-and-error approach was used to evaluate the effect of each time series component on the development of a synthetic water level for the aquifer test. During the trial-anderror analysis, each component was added iteratively, and the effect of that series on the filtering process was evaluated. The final filtering included several components that collectively improved the match. Figure 11 shows the effect of various components on the generation of synthetic water levels in well HAAF 8 (36Q292).

Using background water level time series alone yielded an RMS of residuals of 0.043 and a relatively poor fit to the tidal loading effects (fig. 11A). Using a 6-hour moving average of the background time series the fit was improved (RMS 0.033), but the effects of tidal loading still were evident in the resulting dataset (fig. 11B). Combining the raw background time series with the 6-hour moving average improved the quality of the data series fit, with an RMS of residuals of 0.027 (fig. 11C).

Barometric pressure had a slight influence on estimated water levels. Adding the barometric pressure time series to the analysis improved the fit to an RMS of 0.026 (fig. 11D). Similar attempts were made using the tidal stage time series alone, but this did not produce satisfactory results. Combining the tidal stage and barometric pressure time series gave an RMS of 0.039 and produced a poorer fit than by applying barometric pressure alone (fig. 11E).

The best fit (RMS 0.014) was obtained by combining all of the time series, including the raw and 6-hour moving average time series from the Morrison Plantation background well (36Q020), tidal stage, barometric pressure, gravity tides, and earth tides (fig. 11F). These data were used as a basis for analysis of the drawdown in well HAAF 8 (36Q292) in response to pumping at well HAAF 9 (36Q391) on February 17-18, 2009.

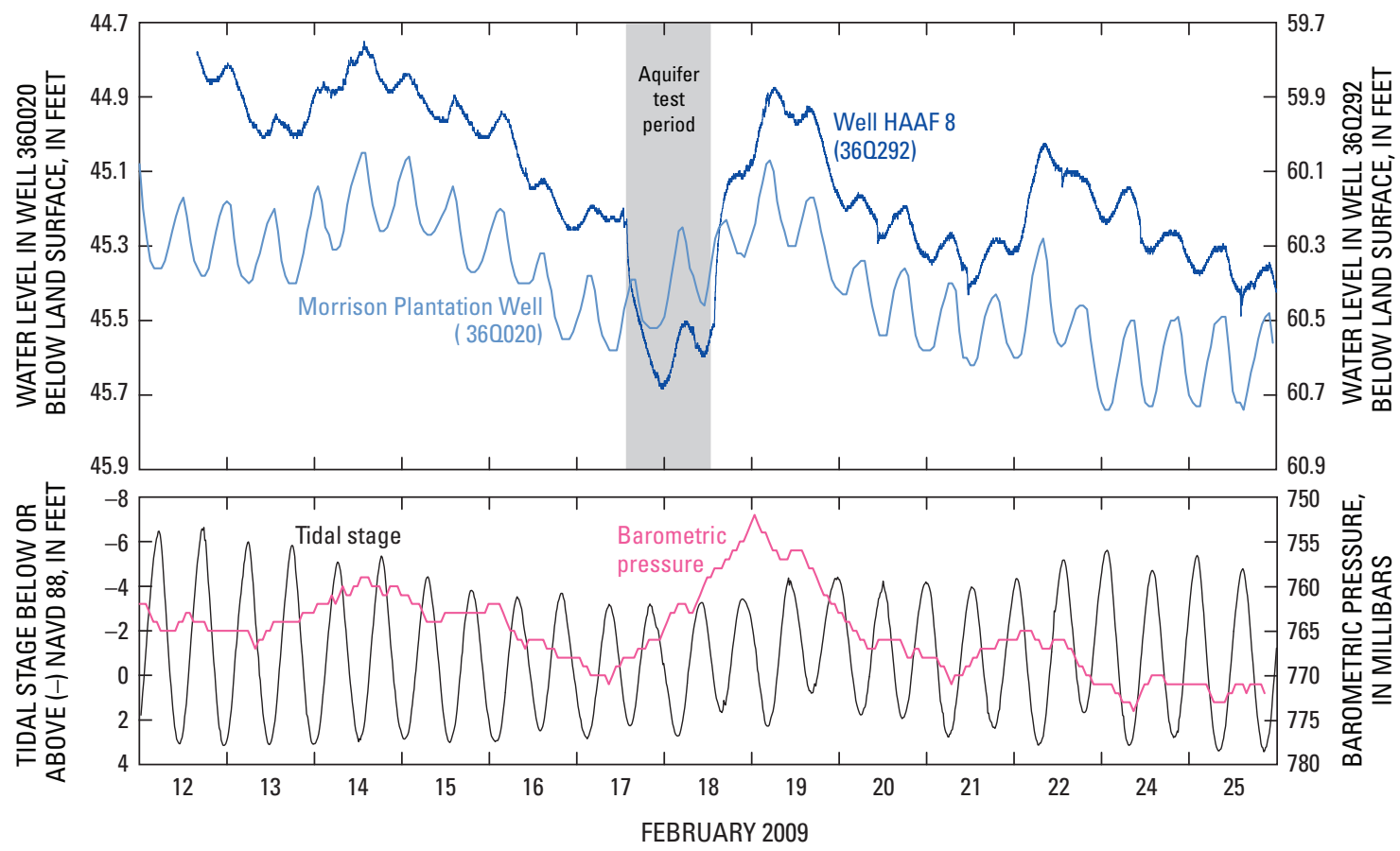

Figure 10. Comparison of water levels at well HAAF 8 (360292) to background water levels at Morrison Plantation observation well (360020) and to stage and barometric pressure at tidal gage 02198773, February 12-25, 2009 (modified from Williams, 2010). 


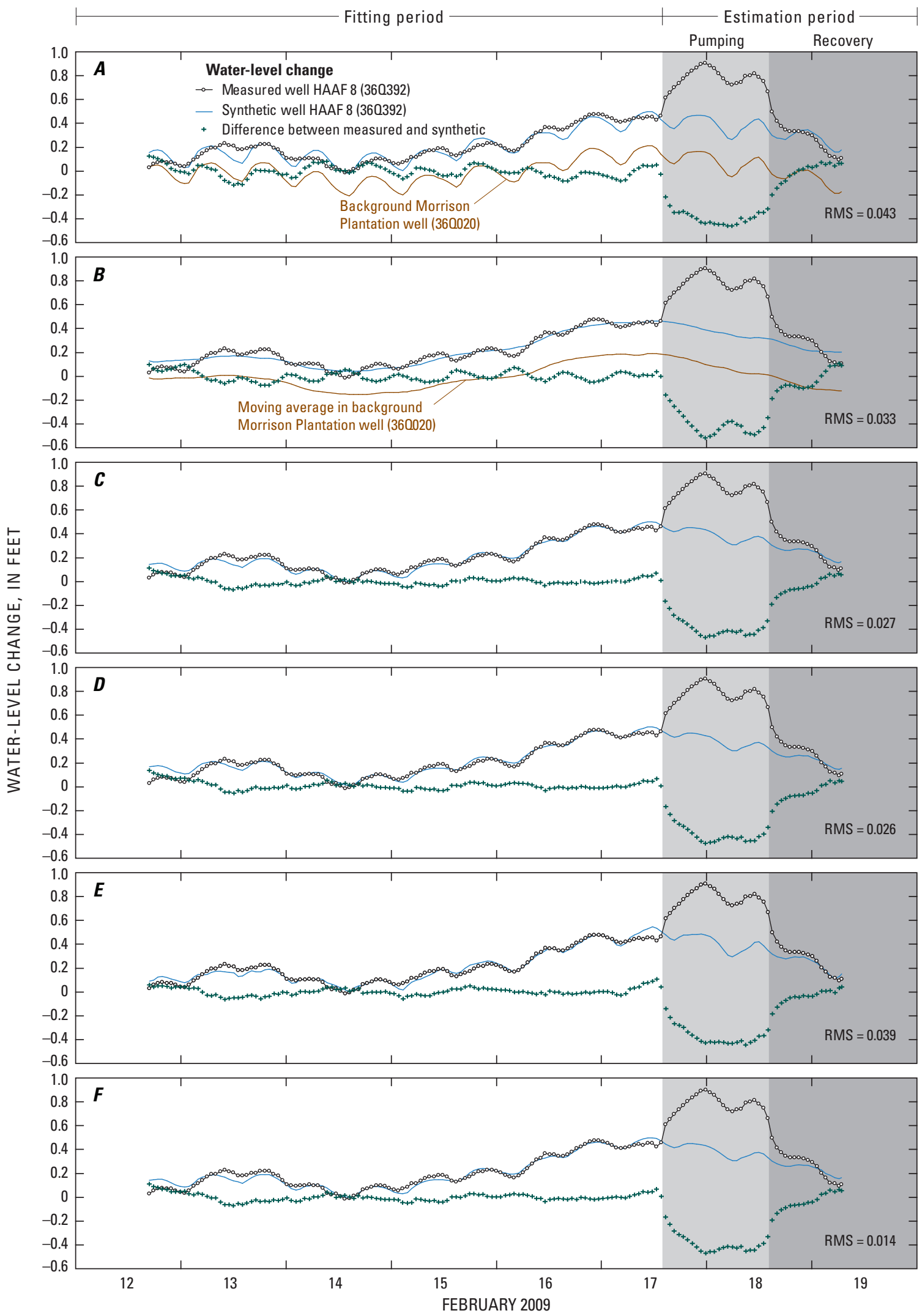

Figure 11. Effects of different time series components on development of a synthetic water level used to filter out extraneous trends from well HAAF 8 (360292), Hunter Army Airfield, Chatham County, Georgia: (A) raw water-level data from well 360020, (B) 6-hour moving average water level from well $360020,(C)$ raw and 6-hour moving average water-level data from well 360020, (D) raw and 6-hour moving-average water level well 360020 and barometric pressure, (E) raw barometric pressure and raw tidal stage data, and (F) raw and 6-hour moving average water-level data from well 360020, tidal stage, barometric pressure, gravity tides, and earth tides (modified from Williams, 2010). [RMS, root mean square of differences between measured and synthetic water levels] 
Analysis of the drawdown data for well HAAF 8 (36Q292) suggested a leaky artesian aquifer response with storage of water in the semiconfining unit (fig. 12). Both the early and late data do not fit the Theis (1935) type curve for an ideal confined aquifer. The departure of the drawdown response from the Theis curve after about 50 minutes suggests appreciable amounts of water are being released from storage, likely from the underlying Lower Floridan confining unit and the LFA.

A transmissivity of about $40,000 \mathrm{ft}^{2} / \mathrm{d}$ and a storage coefficient of $2.5 \times 10^{-4}$ (table 8) were computed for the UFA using the Hantush (1960) leaky aquifer solution (Williams, 2010). This solution assumes that (1) the aquifer is infinite in areal extent, homogeneous, and isotropic, (2) the pumping well is fully or partially penetrating and flow to the pumping well is horizontal, (3) the aquifer is leaky, and flow is unsteady, (4) the water is released from storage instantaneously, (5) the diameter of pumping well is very small, and the storage in the well can be neglected, (6) the confining unit is infinite in areal extent and has a uniform vertical hydraulic conductivity and thickness, (7) the confining unit has an adjacent constant-head source, and (8) flow in the confining unit is vertical. Although all of these conditions may not be absolutely satisfied for this site, the aquifer conditions approximate and satisfy the assumptions relevant for this solution approach.

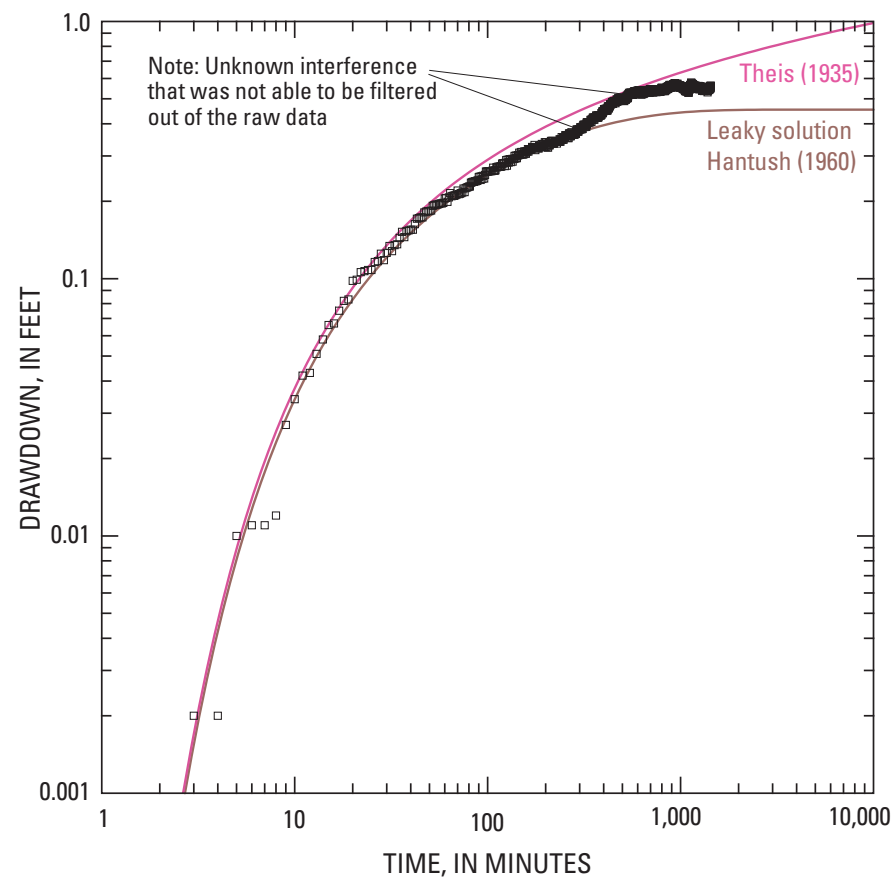

Figure 12. Logarithmic plot of drawdown and time for observation well HAAF 8 (360292) during Upper Floridan aquifer test conducted in well HAAF 9 (360391), Hunter Army Airfield, Chatham County, Georgia, February 17-18, 2009 (modified from Williams, 2010).

\section{Lower Floridan Confining Unit}

The thickness and hydraulic conductivity of the confining unit that separates the UFA and LFA controls the rate of interaquifer leakage. Thickness of the Lower Floridan confining unit was determined by evaluating rock cuttings, borehole geophysical logs, and results of flowmeter testing (figs. 5, 6; table 4).

The Lower Floridan confining unit at well HAAF 11 (36Q392) is interpreted to be present between depths of 560 and $703 \mathrm{ft}$ (fig. 5) and is composed of low permeability chalky and glauconitic limestone in the uppermost part of the middle Eocene Avon Park Formation (figs. 2, 5). This unit is similar in lithology to overlying and underlying rock units (table 4), which precluded the identification of the depth interval of the confining unit during drilling. Following completion of the pilot boring, thickness and location of the confining unit were assessed by using borehole geophysical logs and the results of a flowmeter survey. The Lower Floridan confining unit is about $143 \mathrm{ft}$ thick at HAAF and similarly about $155 \mathrm{ft}$ at the Berwick Plantation well (36Q330), which is $3.7 \mathrm{mi}$ west of the HAAF site (fig. 1). The Lower Floridan confining unit can be distinguished as a zone of relatively higher naturalgamma radiation when compared to the very low naturalgamma radiation in the overlying Ocala Limestone of the UFA (fig. 5). The high natural gamma radiation likely is due to a high percentage of glauconite in the Avon Park Formation.

Borehole flowmeter testing in well HAAF 11 (36Q392) (fig. $6 A$ ) in the $333-1,168 \mathrm{ft}$ open interval indicated the Lower Floridan confining unit contributed little to overall flow in the borehole. In particular, continuous vertical sections of limestone at 556-665 and 675-719 contributed no detectable amounts of water during the $847 \mathrm{gal} / \mathrm{min}$ flowmeter survey. Within the confining unit, a single water-bearing zone at $665-675 \mathrm{ft}$ yielded $36 \mathrm{gal} / \mathrm{min}$ or 4.3 percent of the total borehole flow during the flowmeter survey. This water-bearing zone corresponded to an increase in formation resistivity at that depth (fig. 5).

Prior to installation of 8-inch casing (table 7), the $\mathrm{K}_{\mathrm{h}}$ of the Lower Floridan confining unit was determined by conducting packer-slug tests at four separate intervals within the confining unit: 571-575, 641-645, 688-692, and 698-702 ft (fig. 5). Although the lithology in the confining unit interval was fairly consistent, two variations affected $\mathrm{K}_{\mathrm{h}}$ : (1) fine-grained calcarenite with trace amounts of fine carbonate mud (chalk) disseminated throughout mostly granular limestone and (2) very fine-grained chalky and sandy limestone. The slug tests for the 571-575 ft and 641-645 ft intervals are representative of the first lithology variation with $\mathrm{K}_{\mathrm{h}}$ of 1.1 and $3.1 \mathrm{ft} / \mathrm{d}$, respectively. In the second lithologic variation, the $\mathrm{K}_{\mathrm{h}}$ was $0.16 \mathrm{ft} / \mathrm{d}$ at $688-692 \mathrm{ft}$ and $0.20 \mathrm{ft} / \mathrm{d}$ at $698-702 \mathrm{ft}$.

An approximation of the $\mathrm{K}_{\mathrm{v}}$ of the Lower Floridan confining unit was derived using $\mathrm{K}_{\mathrm{h}}$ data obtained from packer-slug tests and $\mathrm{K}_{\mathrm{v}}$ data obtained from core analysis (table 6). Sediments constituting the Lower Floridan confining unit and upper part of the LFA consist of middle Eocene 
limestone that appears similar in lithologic composition. Because of this similarity, an approximation of the $\mathrm{K}_{\mathrm{v}}$ of the Lower Floridan confining unit was determined using data from the uppermost part of the LFA. A $\mathrm{K}_{\mathrm{h}}: \mathrm{K}_{\mathrm{v}}$ ratio of 8.5:1 was determined by comparing laboratory analyses for $\mathrm{K}_{\mathrm{v}}$ (table 6) in the $817.8-818.4 \mathrm{ft}$ interval $(0.2 \mathrm{ft} / \mathrm{d})$ to the packer test for $\mathrm{K}_{\mathrm{h}}$ (table 7) in the nearby 812-816 ft interval ( $1.7 \mathrm{ft} / \mathrm{d}$ ). Using this relation, the estimated $\mathrm{K}_{\mathrm{v}}$ of the confining unit is estimated to range from 0.02 to $0.36 \mathrm{ft} /$ day (table 7 ). These values are consistent with ranges for $\mathrm{K}_{\mathrm{h}}$ reported by Freeze and Cherry (1979) for limestone and dolomite.

Water in the Lower Floridan confining unit has a low specific conductance compared to deeper units as indicated by the monitoring of drilling fluids while completing the pilot hole in well HAAF 11 (36Q392). Water from the 570-685 ft interval had an average specific conductance of $225 \mu \mathrm{S} / \mathrm{cm}$ (fig. 7).

\section{Lower Floridan Aquifer}

The LFA at well HAAF 11 (36Q392) is present between depths of 703 and 1,080 ft and consists of several high permeability zones in limestone of the middle Eocene Avon Park Formation (fig. 2; table 4). A second round of flowmeter testing conducted in the completed LFA well on August 15, 2009 , provided information on water-bearing intervals in the LFA. Test results indicated that there are six main water-bearing intervals in the LFA: 723-731; 768-785; 818-837; 917-923; 1,027-1,052; and 1,060-1,080 ft (fig. 6B). These intervals seem to coincide with the development of secondary permeability in the aquifer in the form of solution cavities and voids that have a higher permeability than the native-rock matrix (fig. 5). Formation-resistivity logs indicate that each of these water-bearing intervals coincides with an increase in resistivity (fig. 5). Flowmeter-test data indicated that when pumping at a rate of $748 \mathrm{gal} / \mathrm{min}$, the upper two water-bearing zones produced 62.6 percent of the total flow, with $110 \mathrm{gal} / \mathrm{min}$ from the 723 - to $731-\mathrm{ft}$ interval and $359 \mathrm{gal} / \mathrm{min}$ from the $768-$ to 785 -ft interval. The remaining four zones contributed from 1.7 to 18 percent of the flow during the flowmeter test (fig. 6). Flow was not detected beneath a depth of $1,080 \mathrm{ft}$ by the flowmeter. Based on the low contribution from the interval beneath 1,080 ft, the base of the LFA was assigned a depth of 1,080 ft at the HAAF 11 (36Q392) well site.

The quality of water in the LFA was evaluated during drilling by monitoring the specific conductance of reverseair drilling fluids, collecting grab water samples during flowmeter testing, and collecting a composite water sample from the completed well HAAF 11. Monitoring of drilling fluids indicated that the specific conductance in the LFA between depths of 710 and 1,045 ft averaged $262 \mu \mathrm{S} / \mathrm{cm}$. At a depth of $1,055 \mathrm{ft}$, the specific conductance increased abruptly to $1,063 \mu \mathrm{S} / \mathrm{cm}$ and averaged $751 \mu \mathrm{S} / \mathrm{cm}$ for the 1,055-1,165 interval. These higher specific-conductance values suggest an increase in dissolved-solids-concentration that could affect the suitability of the well for water supply.
Drilling was halted at a depth of $1,168 \mathrm{ft}$ to avoid further penetration into zones containing water with a high total dissolved-solids concentration.

Grab water samples were collected using a wireline sampler from five discrete depths on June 22, 2009, and were analyzed for major ions (table 5; figs. 8, 9). Water samples collected in the UFA and LFA indicate a transition with depth (fig. 9) from a slightly sodium-dominated mixed-anion type water in the UFA at a depth of $525 \mathrm{ft}$ to a sodium-chloride type water in the LFA at the 1,075 $\mathrm{ft}$ depth.

Water from the LFA is hard to very hard with an alkalinity of 150-250 mg/L (fig. 8; table 5). Data indicate that with the exception of fluoride, constituent concentrations increase continuously with depth. Water from the deepest interval $(1,075 \mathrm{ft})$ has a chloride concentration of $480 \mathrm{mg} / \mathrm{L}$, which exceeds the USEPA SMCL of $250 \mathrm{mg} / \mathrm{L}$ (U.S. Environmental Protection Agency, 2009). The $240 \mathrm{mg} / \mathrm{L}$ sulfate concentration of water from the same interval is slightly below the USEPA SMCL of $250 \mathrm{mg} / \mathrm{L}$ (U.S. Environmental Protection Agency, 2009). Flowmeter testing indicates that water from the 1,075-ft zone contributes less than 2 percent of the total flow to the well (fig. 6B); thus, the relatively higher concentrations of chloride and sulfate in the deepest interval will not likely affect the quality of the water in the completed well.

A composite sample of water in the LFA was collected and analyzed from well HAAF 11 (36Q392) on August 16, 2009 (table 5), near the completion of a 72-hour aquifer test. Constituent concentrations of the composite sample (703-1,112-ft interval) of the completed well were generally below values for each of the grab samples in the LFA and all were below USEPA MCLs and SMCLs (U.S. Environmental Protection Agency, 2009).

To determine the transmissivity of the LFA, well HAAF 11 (36Q392) was pumped for a 72-hour period at an average rate of $748 \mathrm{gal} / \mathrm{min}$, during August 13-16, 2009 (table 8). Water-level and discharge data were recorded in the pumped well, and water levels were recorded in two observation wells (wells HAAF 5 and HAAF 8) completed in the UFA to assess interaquifer leakage response.

Pumping from well HAAF 9 (36Q391), completed in the UFA about 2,000 ft to the north, was identified as a possible source of interference for the HAAF 11 (36Q392) aquifer test. Because of water-supply needs, pumping at well HAAF 9 (36Q391) could not be discontinued during the 72-hour test and background/recovery periods. For this reason, pumping at the well was maintained at a generally constant rate starting a few days before the start of the aquifer test (August 10, 2009) and was operated on that schedule throughout the duration of the test and recovery period (August 22, 2009). Small fluctuations in the water-system pressure caused slight variations in pumping at well HAAF 9 (36Q391). In addition to adjusting for pumping influences, aquifer test data were corrected for regional trends, barometric pressure, and tidal influences prior to aquifer-test analysis by using the same filtering procedures described earlier for the test conducted in the UFA (Williams, 2010). 
Transmissivity of the LFA was estimated from drawdown and recovery data from the pumped well (well HAAF 11) because no other nearby LFA wells were available for drawdown observations (table 8). Transmissivity calculated using the Theis (1935) solution was 11,000 $\mathrm{ft}^{2} /$ day (Williams, 2010). The Theis (1935) solution assumes the aquifer has an infinite areal extent; is homogeneous, isotropic, and has a uniform thickness; the pumping well is fully penetrating; flow to the well is horizontal; the aquifer is confined; flow is unsteady and water is released instantaneously from storage with decline of hydraulic head; and the effects of borehole storage are small enough to be neglected. The Theis (1935) solution also assumes the aquifer is confined; however, the aquifer test indicates a leaky artesian aquifer response with a flattening of the drawdown curve starting several hundred minutes into the test (fig. 13). Thus, the type curve for this analysis was only matched to early-time data between 7 and 90 minutes. The observed values plotting below the Theis (1935) curve between 1 and 7 minutes are probably the result of borehole storage that were not matched in this analysis.

The Theis (1935) solution for recovery data in a confined aquifer also was used to calculate transmissivity for the aquifer test (Williams, 2010). In the Theis recovery method, the residual drawdown is plotted against time over elapsed time since pumping began $\left(\mathrm{t} / \mathrm{t}^{\prime}\right)$ on a semilogarithmic plot (fig. 13B). A straight-line fit through the observed residual drawdown gives a transmissivity of about $12,000 \mathrm{ft}^{2} /$ day (table 8), which is comparable to the value determined using the drawdown data.

Vertical hydraulic conductivity of the LFA was determined from core samples at depths of 817.8-818.4, 851.8-852.2, and 941.9-942.6 ft (table 6). These samples originally were to have been collected from the Lower Floridan confining unit; however, this interval was not readily identified during drilling, and sampled intervals were designated on the basis of projected depths of the Lower Floridan confining unit according to maps by Miller (1986). Field testing after samples were collected indicated that the samples actually were collected from intervals within the upper part of the LFA. This discrepancy resulted from differing local geology and the coarse resolution of Miller's (1986) maps. Vertical hydraulic conductivity of the LFA, determined by using a flexible wall permeameter following procedures described in ASTM D5084, ranged from 0.13 to $0.34 \mathrm{ft} / \mathrm{d}$.
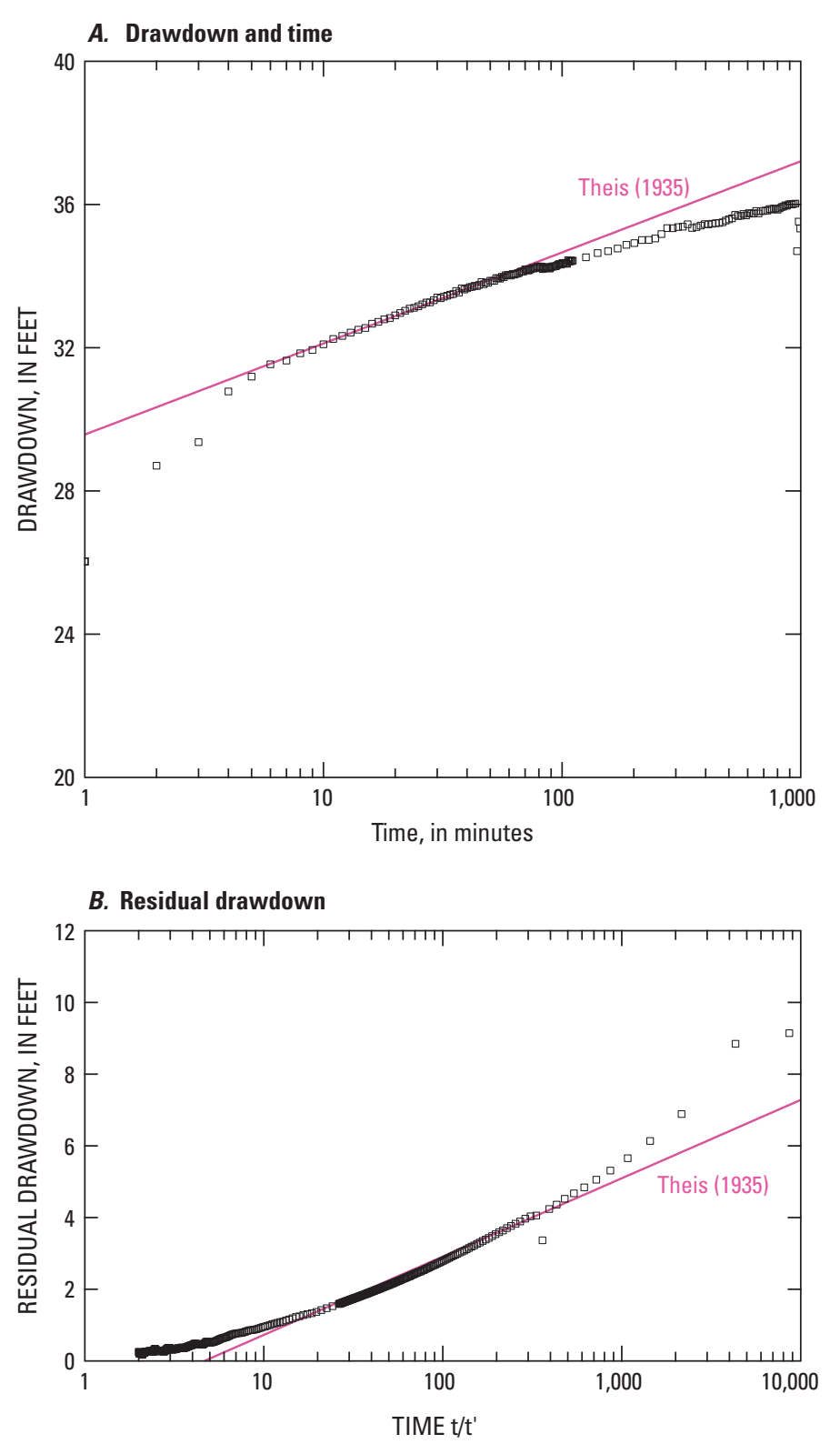

Figure 13. Semi-logarithmic plots of $(A)$ drawdown and time and $(B)$ residual drawdown and $\mathrm{t} / \mathrm{t}$ ' for aquifer test of Lower Floridan aquifer at well HAAF 11 (360392), Hunter Army Airfield, Chatham County, Georgia, August 13-16, 2009. 


\section{Effect of Lower Floridan Aquifer Pumping on the Upper Floridan Aquifer}

Potential effects of pumping the LFA on water levels in the UFA were evaluated by monitoring drawdown response in nearby UFA wells and through model simulation. Observed water-level response in the UFA as a result of pumping the LFA was determined by using water-level data that were filtered for tidal, barometric, and pumping interferences and by following procedures described earlier. These measured drawdowns were used to provide a basis for evaluating the accuracy of model simulations. Model simulation was used to determine long-term (steady-state) leakage response of the UFA to pumping from the LFA, and to estimate the equivalent amount of UFA pumping that would produce similar drawdown.

\section{Observed Water-Level Response}

During the 72-hr LFA test in well HAAF 11 (36Q392), $36.3 \mathrm{ft}$ of drawdown were observed in the pumped well, and small amounts of drawdown were observed in two UFA observation wells. The closest of these observation wells (HAAF 8, 36Q292) is located $176 \mathrm{ft}$ from the pumping well and the farthest (HAAF 5, 36Q288) is located 3,600 ft from the pumping well (fig. 14). Well HAAF 9 (36Q391), located 1,995 $\mathrm{ft}$ from the pumping well, was not used in the drawdown analysis because this well was operational and was being pumped at a generally constant rate during the test. Small fluctuations in water-system pressure caused variations in pumping at well HAAF 9 (36Q391) that masked any observable drawdown resulting from LFA pumping at well HAAF 11.

\section{A. Aquifer test layout}

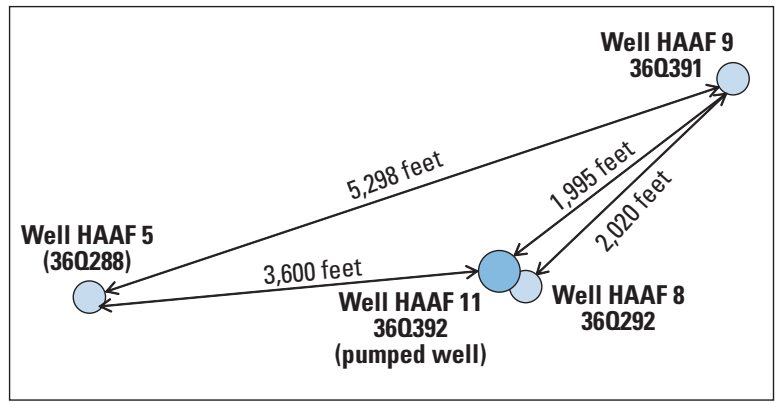

Note: Distance between well HAAF 11 and well HAAF 8 is 176 feet

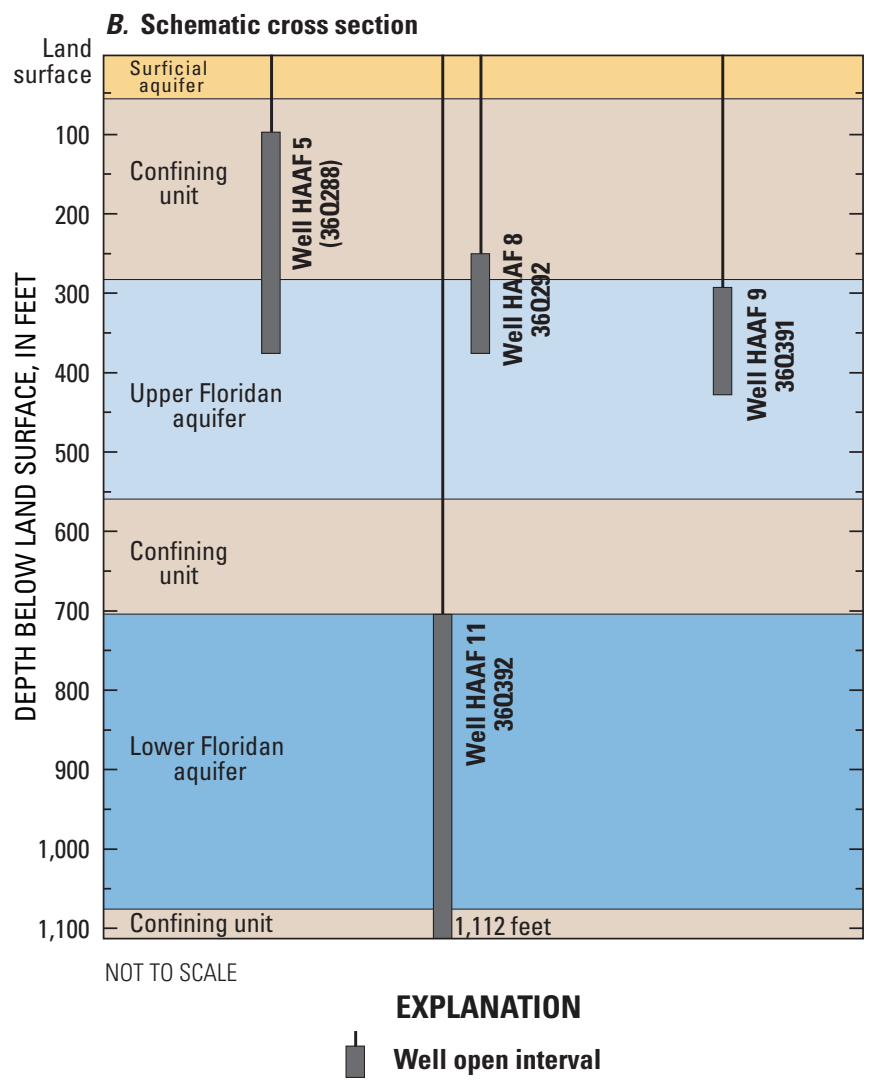

Figure 14. Location and construction characteristics of wells used for aquifer tests at Hunter Army Airfield, Chatham County, Georgia: $(A)$ diagram showing aquifer test layout and $(B)$ schematic section showing the open intervals of the wells in relation to major hydrogeologic units (modified from Williams, 2010). 
Raw, unfiltered water-level data from the 72-hour LFA test and the response at the two UFA observation wells are depicted in figure 15. Visual examination of unfiltered data indicates that drawdown at well HAAF 8 (36Q292) is readily evident, whereas drawdown in well HAAF 5 (36Q288) is less evident but still distinguishable.

Water-level data from wells HAAF 5 (36Q288) and HAAF 8 (36Q292) were filtered to reduce the effects of tidal loading, barometric pressure, regional trends, and pumping at well HAAF 9 (36Q391), following the method presented in Halford (2006). To ensure that local interferences were adequately filtered in order to accurately depict small drawdown values resulting from LFA pumping, the fitting period for the filtering included a week before and several weeks after the test was completed (fig. 16). The amplitude and phase of each time series (background, tide, barometric pressure) were adjusted to create a composite synthetic water-level hydrograph for each observation well that spanned the period of the test, following procedures described earlier for the UFA 24-hour aquifer test.

During the filtering process, the effects of pumping well HAAF 9 (36Q391) on the drawdown response had to be taken into account. For well HAAF 8 (36Q292), the synthetic and measured water levels (fig. 16A) matched fairly well during the week prior to pumping at well HAAF 9 (36Q391). During this pre-test period, well HAAF 9 (36Q391) was taken offline in order to obtain natural background fluctuations. Pumping at well HAAF 9 (36Q391) was started 2 days prior to the startup of the LFA test and was maintained at an average rate of $400 \mathrm{gal} / \mathrm{min}$ until 5 days following the end of the test. At well HAAF 8 (36Q292), the drawdown and recovery response of pumping both at wells HAAF 9 (36Q391) and HAAF 11 (36Q392) are shown in figure 16A. After removing the effects of well HAAF 9 (36Q391) pumping, the total drawdown and recovery response attributed to pumping at well HAAF 11 (36Q392) are estimated to be $0.76 \mathrm{ft}$ (fig. 16A). At well HAAF 5 (36Q288), which is located 3,600 ft away from the LFA well, the total pumping-induced drawdown attributed to well HAAF 11 (36Q392) is estimated to be $0.43 \mathrm{ft}$ (fig. 16B).

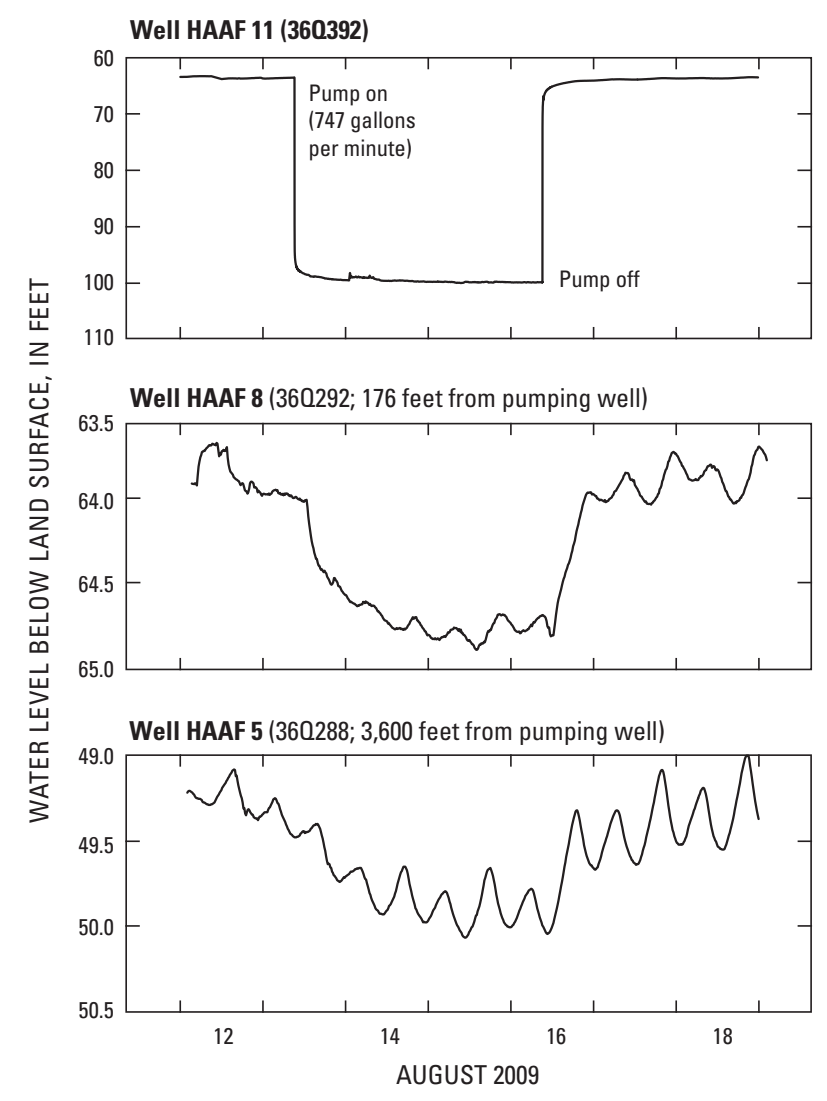

Figure 15. Water levels in the pumped Lower Floridan well (HAAF 11, 360392) and in Upper Floridan observation wells HAAF 8 (360292) and HAAF 5 (360288) before, during, and after the 72-hour aquifer test of the Lower Floridan aquifer, Hunter Army Airfield, Chatham County, Georgia, August 11-19, 2009 (modified from Williams, 2010). 


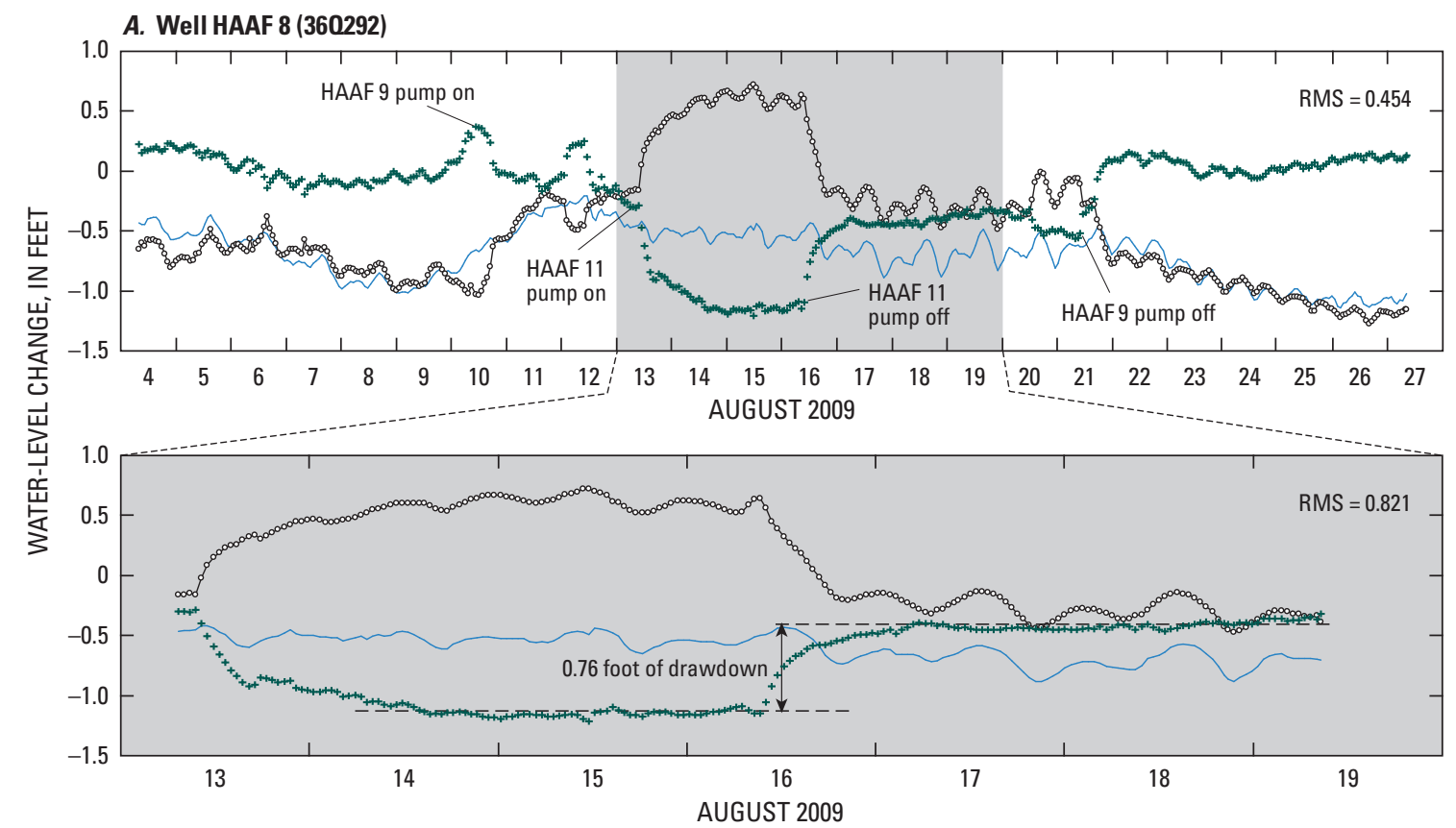

B. Well HAAF 5 (360288)

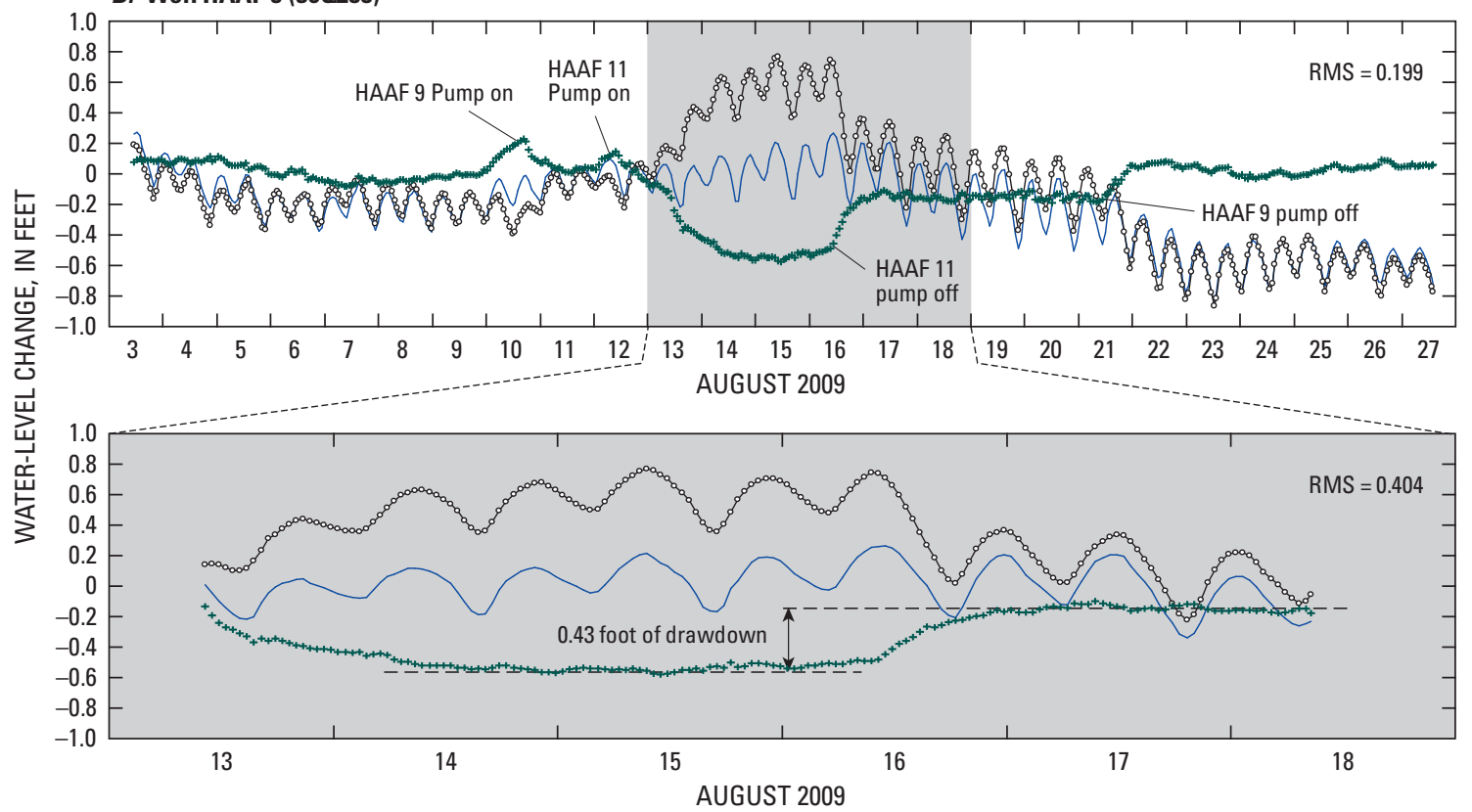

\section{EXPLANATION}

Water-level change

$\rightarrow$ Measured

- Synthetic

+ Difference between measured and synthetic

Figure 16. Estimated drawdown calculated in Upper Floridan wells (A) HAAF 8 (360292) and (B) HAAF 5 (360288) during the 72-hour aquifer test of the Lower Floridan aquifer in well HAAF 11 (360392), Hunter Army Airfield, Chatham County, Georgia (modified from Williams, 2010). 


\section{Model Simulation}

A revised regional groundwater-flow model was used to simulate the water-level response of the UFA in selected observation wells to pumping from the LFA at well HAAF 11. The revised model was also used to simulate the equivalent pumping rate in a hypothetical UFA well at the same location as HAAF 11 (36Q392) that would produce a comparable drawdown to that resulting from pumping well HAAF 11.

To simulate the steady-state effect on groundwater flow of pumping the new LFA well at HAAF, the existing USGS MODFLOW model of Payne and others (2005) was modified based on hydrogeological information obtained from field investigations (described earlier) and from existing wells in the area. The model grid was modified to a finer $10-\mathrm{ft}$ by $10-\mathrm{ft}$ cell size near well HAAF 11 (36Q392) to enable more accurate simulations at smaller scale. Revisions to the regional model of Payne and others (2005) are described in the appendix. The location of the regional model is shown on in figure 17.

The revised model used regional pumping and boundary conditions during 2000 as a "base case" for comparing drawdown and water-budget changes simulated in response to pumping well HAAF 11 (36Q392). Pumping well HAAF 11 (36Q392) at a rate of $748 \mathrm{gal} / \mathrm{min}$ resulted in a simulated maximum steady-state drawdown of $36.2 \mathrm{ft}$ in the LFA, which is nearly identical to the $36.3 \mathrm{ft}$ of drawdown observed in well HAAF 11 (36Q392) during the 72-hour aquifer test. Simulated steady-state drawdown in the LFA was greater than $1 \mathrm{ft}$ over a 146-square-mile ( $\left.\mathrm{mi}^{2}\right)$ area (fig. 17).

\section{Interaquifer Leakage and Drawdown Response}

Pumping from the LFA at well HAAF 11 (36Q392) also resulted in a simulated drawdown response in the overlying UFA because of leakage through the Lower Floridan confining unit (fig. 18). Model simulations indicate that steady-state drawdown in the UFA was greater than $1 \mathrm{ft}$ over a $141 \mathrm{mi}^{2}$ area and was $1.9 \mathrm{ft}$ near well HAAF 5 (36Q288) and $2.03 \mathrm{ft}$ near wells HAAF 11 (36Q392) and HAAF 8 (36Q292).

The GaEPD interim permit strategy for the LFA (Nolton Johnston, Georgia Environmental Protection Division, written commun., January 28, 2003) states that "the applicant must offset the impact of the LF [Lower Floridan] pumping by reducing nearby UF [Upper Floridan] permitted pumping in the same general area (within a 5 mi radius) by an amount equal to or greater than the determined UF leakage." To assess the amount of leakage resulting from pumping in the Lower Floridan aquifer, the steady-state water budget before and after the initiation of pumping at well HAAF 11 (36Q392) was compared (table 9; fig. 19).

Table 9. Simulated steady-state water budget for 2000 and after initiation of pumping 748 gallons per minute (1.08 million gallons per day) at well HAAF 11 (360392), Hunter Army Airfield, Chatham County, Georgia.

[Values reported to three significant digits and may not sum to totals because of independent rounding; $<$, less than]

\begin{tabular}{|c|c|c|c|c|c|c|c|c|c|c|c|}
\hline \multirow{3}{*}{$\begin{array}{l}\text { Hydro- } \\
\text { geologic } \\
\text { unit }\end{array}$} & \multirow{3}{*}{ Layer } & \multicolumn{10}{|c|}{ Simulated flow, in million gallons per day } \\
\hline & & \multicolumn{2}{|c|}{ Pumpage } & \multicolumn{2}{|c|}{$\begin{array}{c}\text { Recharge from } \\
\text { general head } \\
\text { boundary }\end{array}$} & \multicolumn{2}{|c|}{$\begin{array}{c}\text { Discharge to } \\
\text { general head } \\
\text { boundary }\end{array}$} & \multicolumn{2}{|c|}{$\begin{array}{l}\text { Inflow along } \\
\text { lateral boundary }\end{array}$} & \multicolumn{2}{|c|}{$\begin{array}{l}\text { Outflow along } \\
\text { lateral boundary }\end{array}$} \\
\hline & & $\begin{array}{l}\text { Year } \\
2000\end{array}$ & $\begin{array}{c}\text { Well } \\
\text { HAAF } 11 \\
\text { added }\end{array}$ & $\begin{array}{l}\text { Year } \\
2000\end{array}$ & $\begin{array}{c}\text { Well } \\
\text { HAAF } 11 \\
\text { added }\end{array}$ & $\begin{array}{l}\text { Year } \\
2000\end{array}$ & $\begin{array}{c}\text { Well } \\
\text { HAAF } 11 \\
\text { added }\end{array}$ & $\begin{array}{l}\text { Year } \\
2000\end{array}$ & $\begin{array}{l}\text { Well } \\
\text { HAAF } 11 \\
\text { added }\end{array}$ & $\begin{array}{l}\text { Year } \\
2000\end{array}$ & $\begin{array}{c}\text { Well } \\
\text { HAAF } 11 \\
\text { added }\end{array}$ \\
\hline $\begin{array}{l}\text { Confining } \\
\text { unit }\end{array}$ & 2 & 0 & 0.00 & 46.1 & 46.1 & 4.7 & 4.70 & $<0.001$ & $<0.001$ & $<0.001$ & $<0.001$ \\
\hline $\begin{array}{l}\text { Brunswick } \\
\text { aquifer } \\
\text { system }\end{array}$ & 3 & 0.241 & 0.241 & $<0.001$ & $<0.001$ & $<0.001$ & $<0.001$ & $<0.001$ & $<0.001$ & $<0.001$ & $<0.001$ \\
\hline $\begin{array}{l}\text { Confining } \\
\text { unit }\end{array}$ & 6 & 0 & 0.00 & $<0.001$ & $<0.001$ & $<0.001$ & $<0.001$ & 0.004 & $<0.001$ & $<0.001$ & $<0.001$ \\
\hline $\begin{array}{l}\text { Lower } \\
\quad \text { Floridan } \\
\text { aquifer }\end{array}$ & 7 & 129 & 130 & $<0.001$ & $<0.001$ & $<0.001$ & $<0.001$ & 16.6 & $<0.001$ & 1.97 & $<0.001$ \\
\hline \multicolumn{2}{|c|}{ Total all layers } & 798 & 800 & 465 & 466 & 129 & 129 & 732 & 742 & 268 & 288 \\
\hline
\end{tabular}



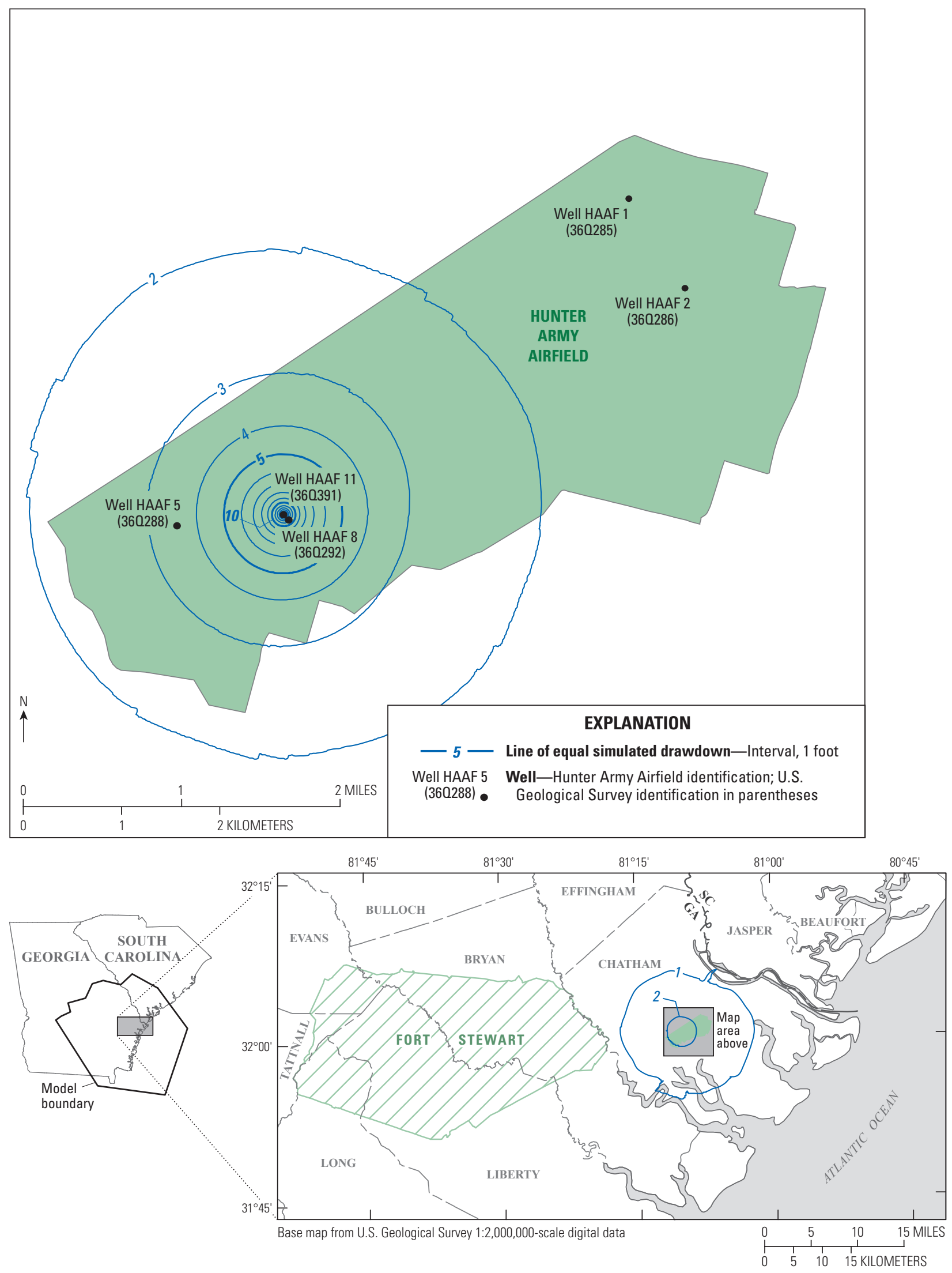

Figure 17. Simulated steady-state drawdown in the Lower Floridan aquifer resulting from pumping well HAAF 11 (360392) at 748 gallons per minute, Hunter Army Airfield and vicinity, coastal Georgia. 

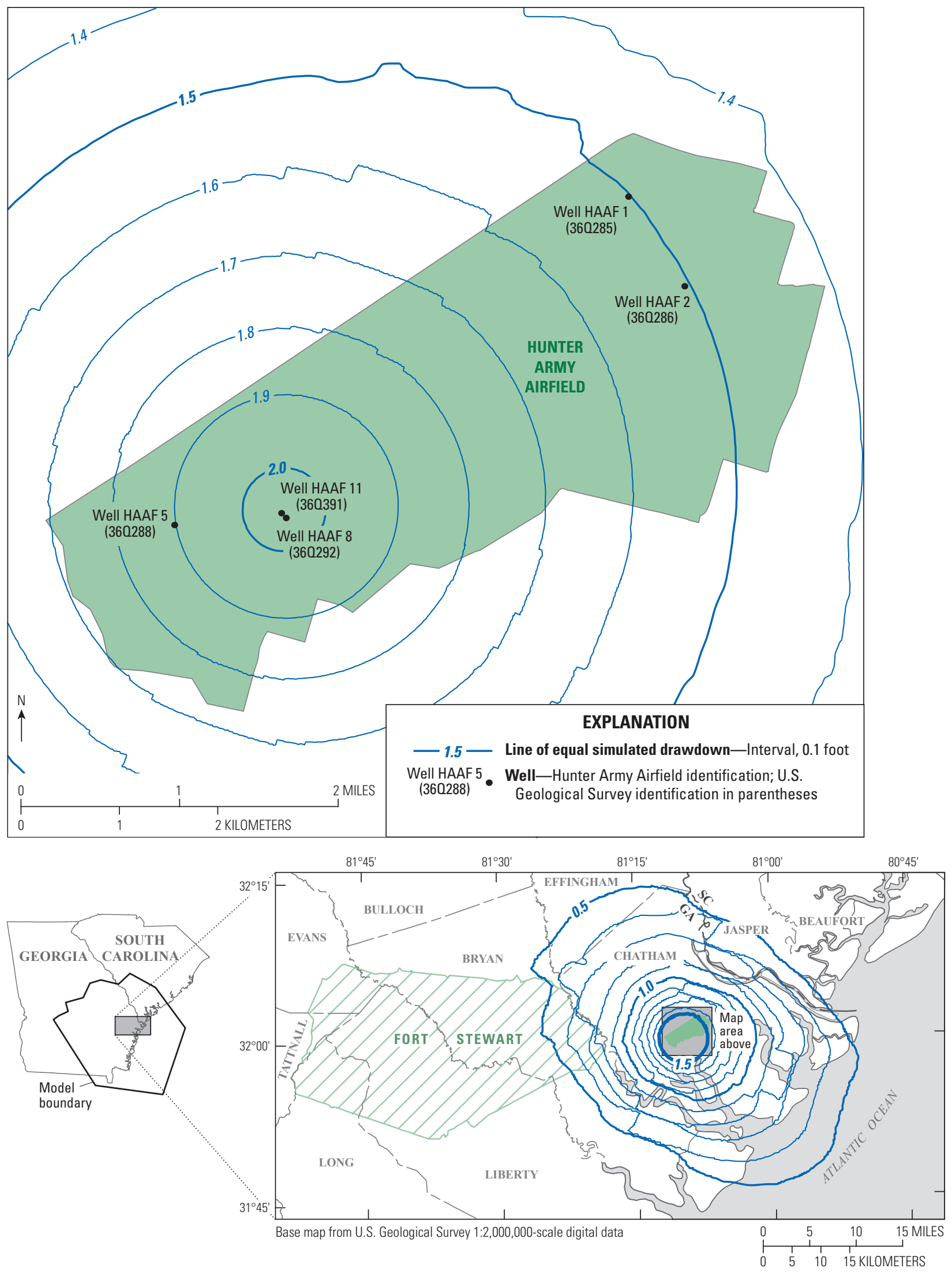

Figure 18. Simulated steady-state drawdown in the Upper Floridan aquifer resulting from pumping well HAAF 11 (360392) at 748 gallons per minute, Hunter Army Airfield and vicinity, coastal Georgia. 


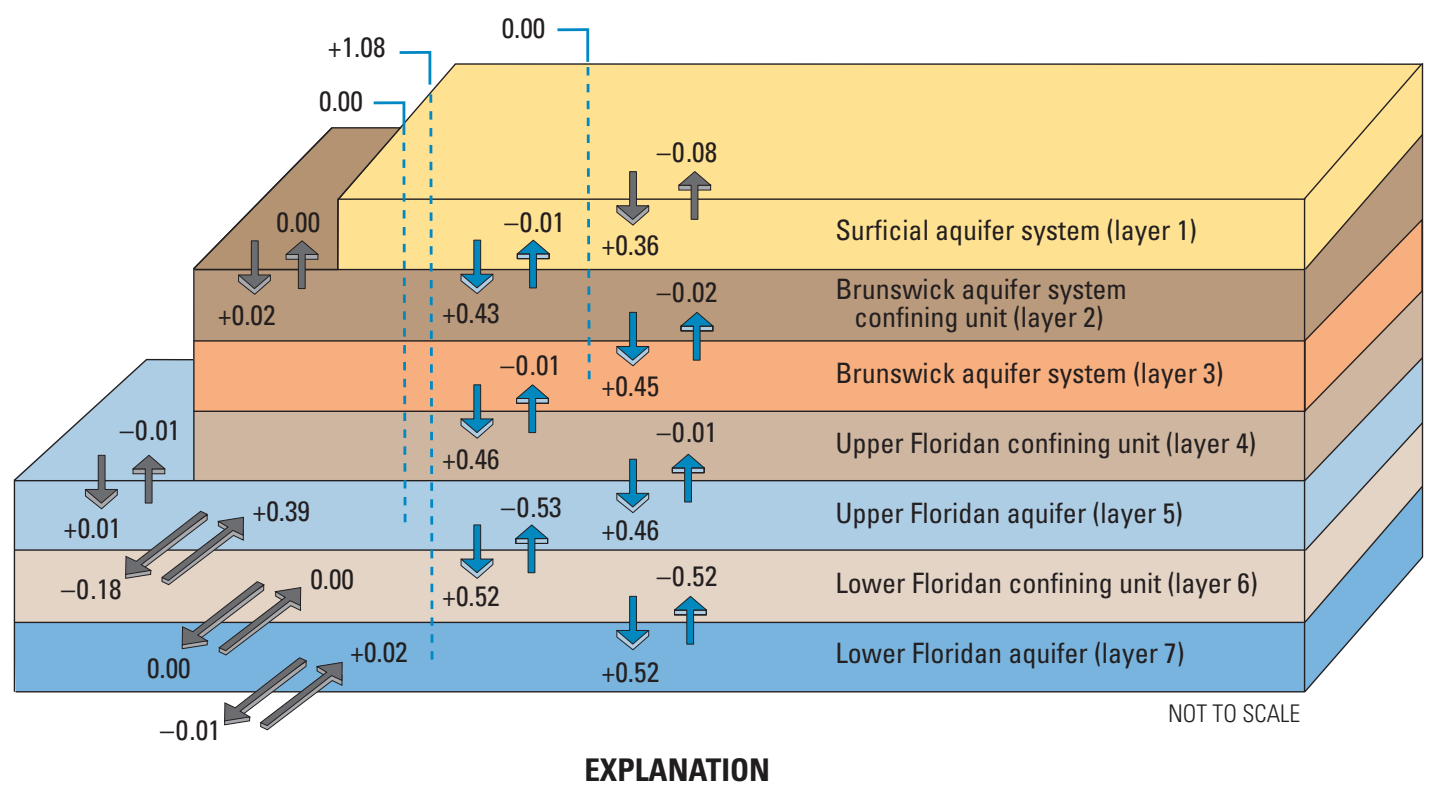

EXPLANATION

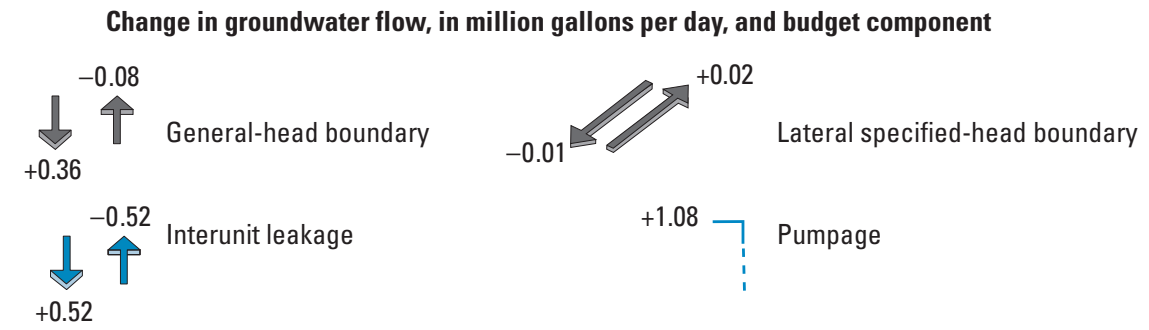

Figure 19. Change in simulated steady-state water budget resulting from initiation of pumping at well HAAF 11 (360392), Hunter Army Airfield, Chatham County, Georgia (modified from Payne and others, 2005).

Pumping $1 \mathrm{Mgal} / \mathrm{d}(748 \mathrm{gal} / \mathrm{min})$ at well HAAF 11 (36Q392) resulted in small changes and redistribution of flow among model layers, including increased downward and decreased upward leakage in all layers, and increased inflow and decreased outflow from lateral boundaries in the UFA and LFA. In the surficial aquifer, pumping at well HAAF 11 (36Q392) resulted in increased inflow (recharge) from the general head boundary ( $0.36 \mathrm{Mgal} / \mathrm{d})$. Flow to well HAAF 11 (36Q392) was derived from increased lateral flow from the specified-head boundary $(0.02 \mathrm{Mgal} / \mathrm{d})$, from increased leakage through the Lower Floridan confining unit $(0.52 \mathrm{Mgal} / \mathrm{d})$, and by reductions in discharge to the Lower Floridan confining unit $(0.52 \mathrm{Mgal} / \mathrm{d})$ and to lateral specified-head boundaries $(0.01 \mathrm{Mgal} / \mathrm{d})$.

The simulated steady-state water budget was further evaluated using the MODFLOW postprocessor ZONEBUDGET (Harbaugh, 1990). ZONEBUDGET enables summation of flow entering and leaving a designated subarea of the model domain. For this evaluation, three zones surrounding well HAAF 11 (36Q392) were designated: $0-0.5 \mathrm{mi}, 0.5-1 \mathrm{mi}$, and greater than $1 \mathrm{mi}$. The percentage of leakage from the UFA that contributed flow to the LFA at well HAAF 11 (36Q392) is shown on figure 20. About 65 percent of the water that was contributed to well HAAF 11 (36Q392) came from within $1 \mathrm{mi}$ of the pumped well, of which 36 percent came from within $0.5 \mathrm{mi}$ of the pumped well. The larger contribution of water resulted from a larger head gradient between the pumped well and the overlying aquifer in areas close to the pumped well.

\section{Upper Floridan Aquifer Drawdown Offset}

As part of the interim permitting strategy, GaEPD provided a hydrogeological study protocol, that states that a groundwater model shall be used (Nolton Johnston, Georgia Environmental Protection Division, written commun., January 28, 2003) “... to simulate the equivalent Upper Floridan pumping that induces the identical maximum drawdown in the Upper Floridan that would be expected as a result of pumping the Lower Floridan."

To replicate simulated drawdown in the UFA in response to pumping in the LFA at well HAAF 11, a series of steady-state simulations were conducted using the revised model. Each simulation involved applying a different pumping rate to a hypothetical UFA well located at the site of well HAAF 11 (36Q392) and running the model under steady-state conditions. Profiles (fig. 21) and maps (fig. 22) show the simulated drawdown in the UFA (1) resulting from LFA pumping in well HAAF 11 (36Q392) at $748 \mathrm{gal} / \mathrm{min}$ and (2) resulting from pumping a hypothetical UFA well at the same location as well HAAF 11 (36Q392) at rates of 189 and $650 \mathrm{gal} / \mathrm{min}$. 

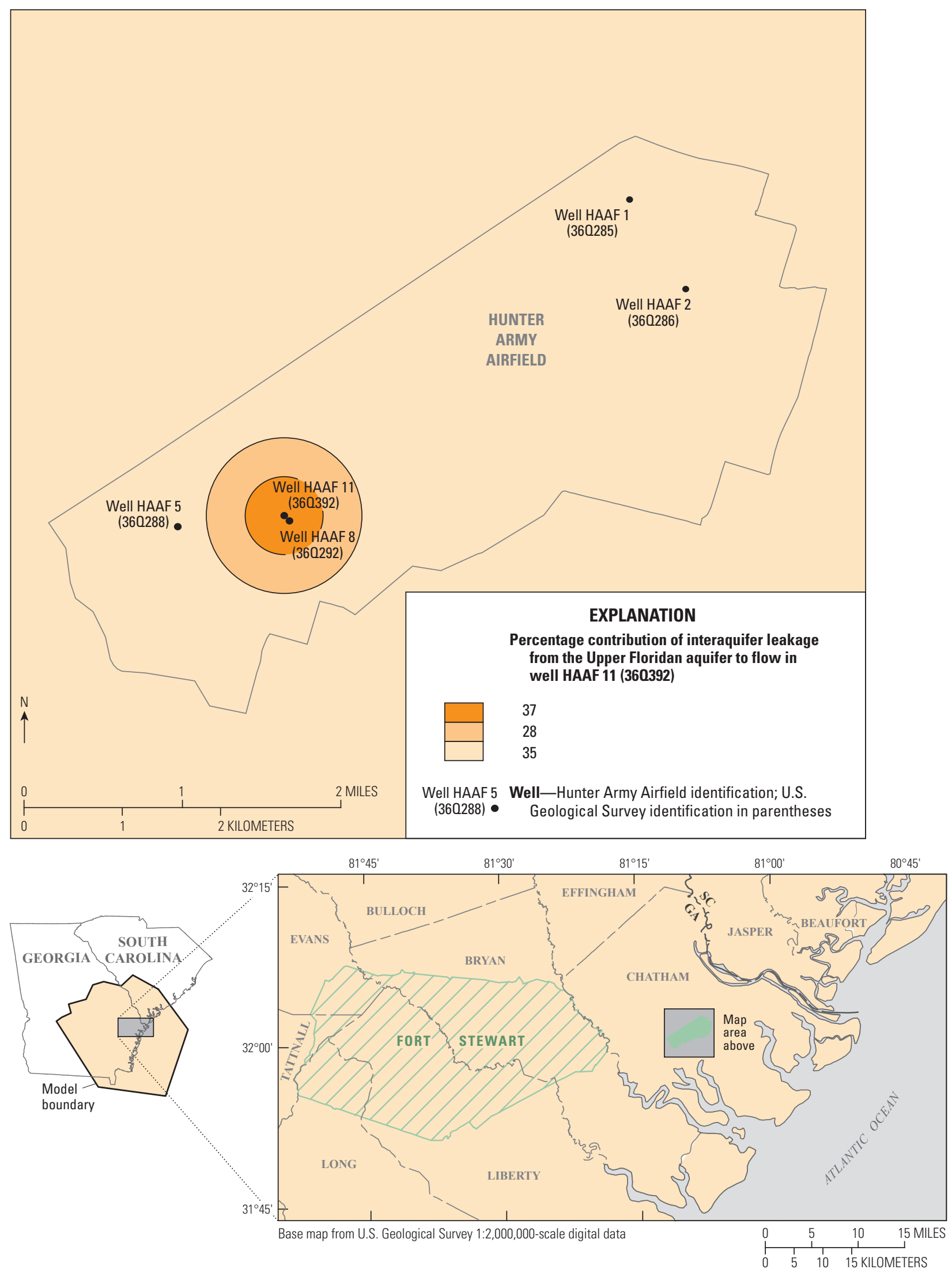

Figure 20. Percentage of interaquifer leakage from the Upper Floridan aquifer contributing flow to well HAAF 11 (360392) pumping at a rate of 748 gallons per minute (1.08 million gallons per day), Hunter Army Airfield and vicinity, coastal Georgia. 

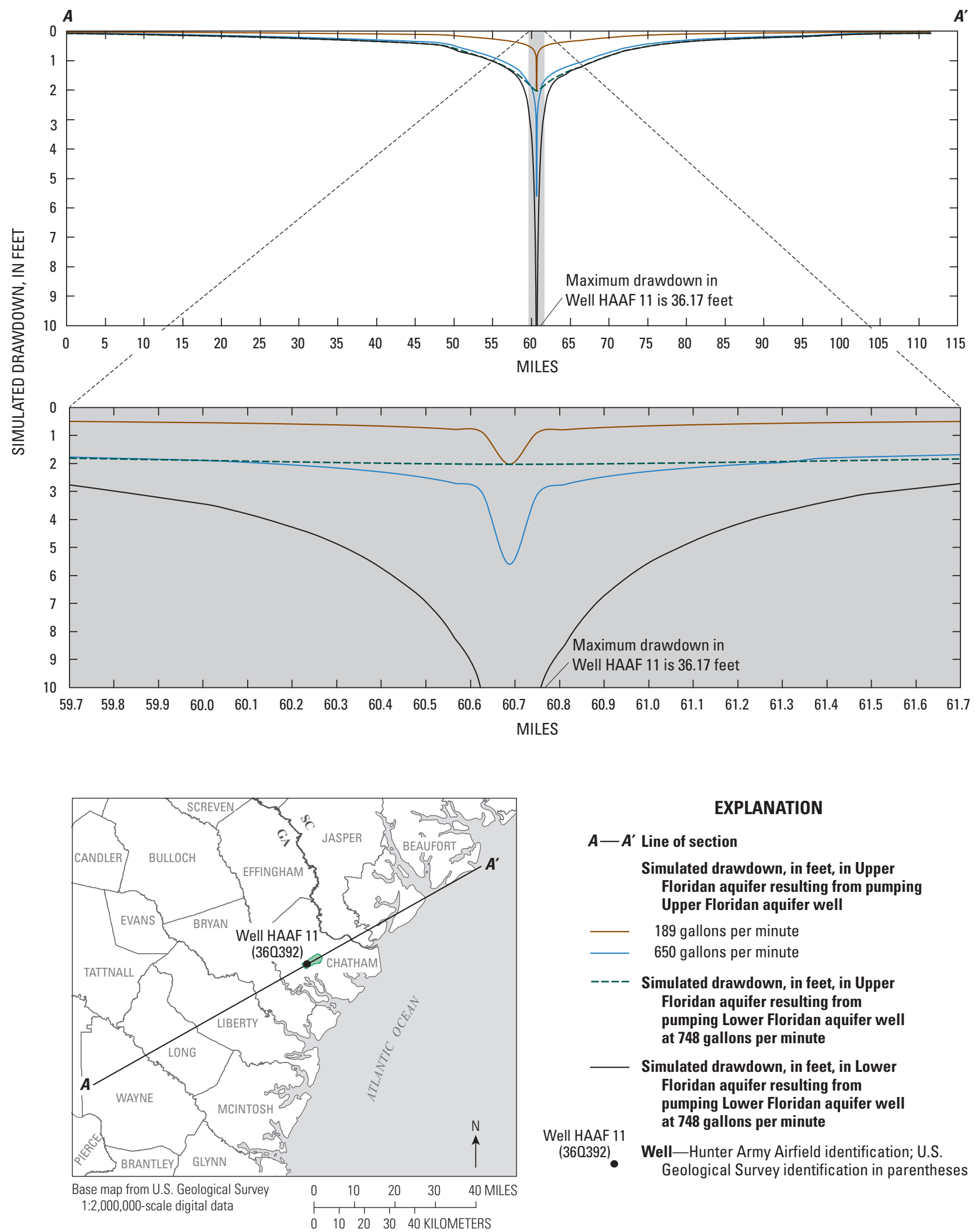

\section{EXPLANATION}

$\boldsymbol{A}-\boldsymbol{A}^{\prime}$ Line of section

Simulated drawdown, in feet, in Upper Floridan aquifer resulting from pumping Upper Floridan aquifer well

189 gallons per minute 650 gallons per minute

Simulated drawdown, in feet, in Upper Floridan aquifer resulting from pumping Lower Floridan aquifer well at 748 gallons per minute

Simulated drawdown, in feet, in Lower Floridan aquifer resulting from pumping Lower Floridan aquifer well at 748 gallons per minute (360392)

Well—Hunter Army Airfield identification; U.S. Geological Survey identification in parentheses

Figure 21. Profile showing simulated steady-state drawdown in the Upper and Lower Floridan aquifers resulting from pumping in the Lower Floridan aquifer at well HAAF 11 (360392) and from pumping the Upper Floridan aquifer at rates of 189 and 650 gallons per minute at a hypothetical Upper Floridan aquifer well at the site of well HAAF 11 (360392), Hunter Army Airfield and vicinity, coastal Georgia. 

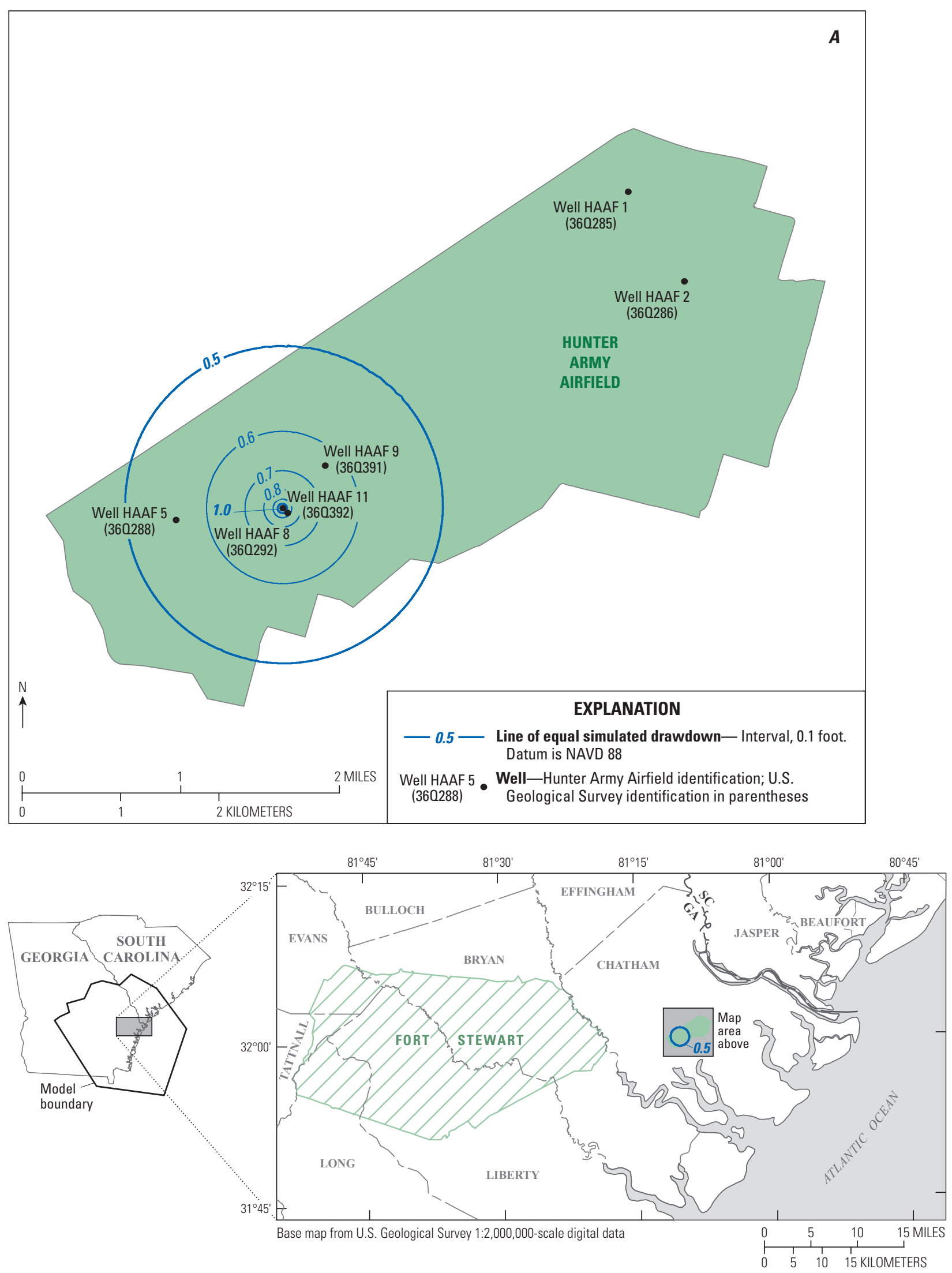

Figure 22. Simulated drawdown in the Upper Floridan aquifer resulting from pumping a hypothetical Upper Floridan aquifer well at the site of well HAAF 11 (360392) at rates of $(A) 189$ and $(B) 650$ gallons per minute, Hunter Army Airfield and vicinity, coastal Georgia. 

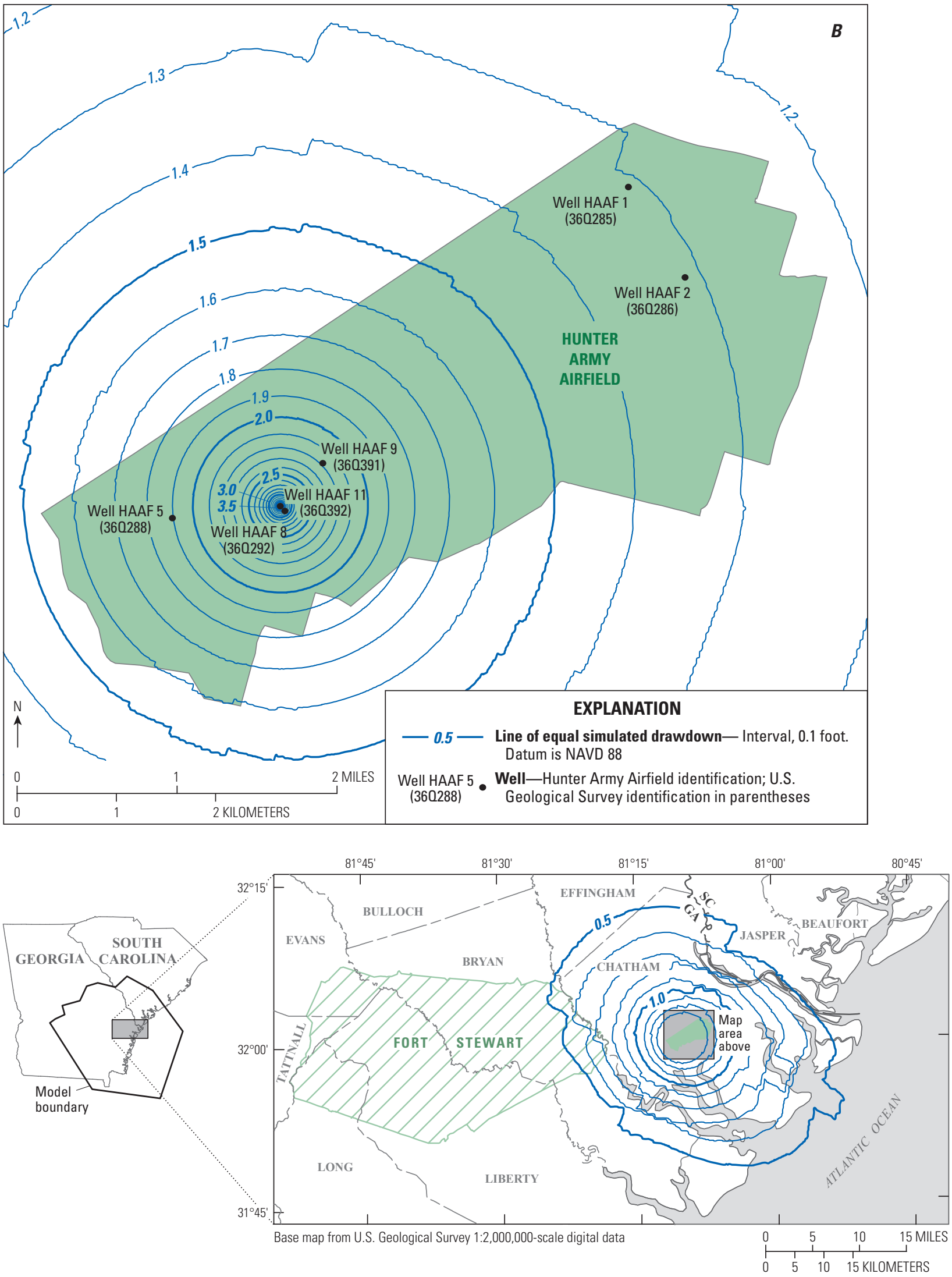

Figure 22. Simulated drawdown in the Upper Floridan aquifer resulting from pumping a hypothetical Upper Floridan aquifer well at the site of well HAAF 11 (360392) at rates of $(A) 189$ and $(B) 650$ gallons per minute, Hunter Army Airfield and vicinity, coastal Georgia.-Continued 
Simulated water-level profiles indicate that drawdown resulting from pumping the hypothetical UFA well at a rate of $189 \mathrm{gal} / \mathrm{min}$ approximates the maximum drawdown resulting from pumping the LFA at well HAAF 11, but is less at distances greater than $0.1 \mathrm{mi}$ from the pumped well (fig. 21). Conversely, drawdown resulting from pumping at a rate of $650 \mathrm{gal} / \mathrm{min}$ approximates that resulting from pumping in the LFA at distances greater than $0.1 \mathrm{mi}$ from the pumped well, but is greater closer to the pumped well. The poor overall match to drawdown resulting from interaquifer leakage results from differences in how the model simulates stress. Leakage stress occurs over a wide area, not at a localized position as is the case with an individual pumping well. Thus, drawdown resulting from leakage shows a more gradual lateral gradient and covers a wider area than drawdown resulting from a well being pumped directly from the UFA.

The area in which simulated drawdown exceeded $1 \mathrm{ft}$ further illustrates differences in how the model simulates stress in the form of interaquifer leakage from the simulation of pumping a single UFA well (fig. 22). Simulated drawdown in the UFA that resulted from pumping the LFA covered a 141- $\mathrm{mi}^{2}$ area (fig. 18), whereas drawdown that resulted from pumping an UFA well at rates of 189 and $650 \mathrm{gal} / \mathrm{min}$ covered areas of $0.003 \mathrm{mi}^{2}$ and $88.7 \mathrm{mi}^{2}$, respectively (fig. 22). In general, the cone of depression formed in response to pumping in the UFA was much steeper near the pumped well, but diminished in magnitude away from the pumped well, whereas the cone of depression formed in response to pumping in the LFA was less steep, but covered a larger area. Neither pumping rate matched the $0.52 \mathrm{Mgal} / \mathrm{d}$ (361 gal $/ \mathrm{min}$ ) simulated leakage rate.

\section{Effect of Pumping Offsets on Groundwater Levels at Hunter Army Airfield}

To assess the effect of pumping redistribution on current groundwater conditions at HAAF, three model scenarios were run:

- Scenario A-Effect of pumping the LFA at well HAAF 11, 24 hours per day at a rate of $748 \mathrm{gal} / \mathrm{min}$ $(1.08 \mathrm{Mgal} / \mathrm{d})$, and reducing pumping in existing UFA HAAF supply wells by $187 \mathrm{gal} / \mathrm{min}(0.27 \mathrm{Mgal} / \mathrm{d})$ or 25 percent of the pumping rate at well HAAF 11 (36Q392). The reduction in withdrawals from the UFA is close to the $189 \mathrm{gal} / \mathrm{min}$ rate required to match the maximum drawdown simulated near well HAAF 11.

- Scenario B-Effect of pumping the LFA at well HAAF 11, 24 hours per day at a rate of $748 \mathrm{gal} / \mathrm{min}$ (1.08 Mgal/d), and reducing pumping in existing UFA HAAF supply wells by $374 \mathrm{gal} / \mathrm{min}(0.54 \mathrm{Mgal} / \mathrm{d})$ or 50 percent of the pumping rate at well HAAF 11
(36Q392). The reduction in withdrawals from the UFA is close to the simulated steady-state leakage rate of $361 \mathrm{gal} / \mathrm{min}$.

- Scenario C-Effect of pumping the LFA at well HAAF 11 (36Q392) at a rate of $374 \mathrm{gal} / \mathrm{min}$ (0.54 Mgal $/ \mathrm{d})$, and reducing pumping in existing UFA HAAF supply wells by $187 \mathrm{gal} / \mathrm{min}(0.27 \mathrm{Mgal} / \mathrm{d})$ or 50 percent of the pumping rate at well HAAF 11 (36Q392). Note that all withdrawals from the UFA at wells HAAF 8 (36Q292) and HAAF 9 (36Q391) were eliminated for this scenario.

For each scenario, permitted withdrawals for the UFA at HAAF during 2005 were apportioned on the basis of the reported well yield of the four main withdrawal wellsHAAF 1 (36Q285), HAAF 2 (36Q286), HAAF 9 (36Q391), and HAAF 8 (36Q292) — and reduced by a designated percentage (table 10). Withdrawal from well HAAF 11 (36Q392) was held constant at $1.08 \mathrm{Mgal} / \mathrm{d}$ (748 gal $/ \mathrm{min}$ ) for scenarios $\mathrm{A}$ and $\mathrm{B}$, and was decreased by one-half for scenario C (374 gal/min or $0.54 \mathrm{Mgal} / \mathrm{d}$ ). For scenarios A and B, pumping reductions in the UFA were uniformly distributed among wells HAAF 1 (36Q285), HAAF 2 (36Q286), HAAF 8 (36Q292), and HAAF 9 (36Q391) on the basis of the well's contribution to the overall yield (table 10). For scenario C, pumping was eliminated at wells HAAF 8 (36Q292) and HAAF 9 (36Q391), with the balance of pumping reductions at wells HAAF 1 (36Q285) and HAAF 2 (36Q286). Simulated drawdown at selected well sites for scenarios A, B, and C is listed in table 10. Maps showing water-level changes in the UFA resulting from scenarios A and B are provided in figures 23-24. A map showing drawdown for scenario $\mathrm{C}$ is not provided because drawdown was less than $0.5 \mathrm{ft}$ throughout the area.

For each scenario, pumping reductions in the existing HAAF UFA wells resulted in decreased magnitude and extent of drawdown when compared to a scenario in which a well in the LFA was pumped without reducing withdrawals in the UFA (fig. 18). Pumping at well HAAF 11 (36Q392) in the LFA without reducing pumping in the UFA resulted in a simulated drawdown in the UFA of $2.03 \mathrm{ft}$ near well HAAF 11, with drawdown exceeding $1 \mathrm{ft}$ over a $141-\mathrm{mi}^{2}$ area. For scenario A, simulated drawdown was $1.59 \mathrm{ft}$ near well HAAF 11 (36Q392), and the area in which drawdown exceeded $1 \mathrm{ft}$ covered $40.5 \mathrm{mi}^{2}$ (fig. 23; table 10). Simulated drawdown in the UFA for scenario B was $1.15 \mathrm{ft}$ at well HAAF 11 (36Q392), and the simulated 1-ft drawdown contour covered an area of $4.37 \mathrm{mi}^{2}$ (fig. 24; table 10). For scenario C, simulated drawdown in the UFA was less than $0.5 \mathrm{ft}$ throughout the area and was $0.42 \mathrm{ft}$ near well HAAF 11 (36Q392) (table 10). None of the scenarios resulted in noticeable changes in the configuration of the simulated potentiometric surface and related groundwater-flow directions for the UFA (fig. 25). 
Table 10. Simulated pumping and drawdown for the year 2005 permitted pumping rate and model scenarios A, B, and C.

[Mgal/d, million gallons per day; gal/min, gallons per minute; —, not applicable]

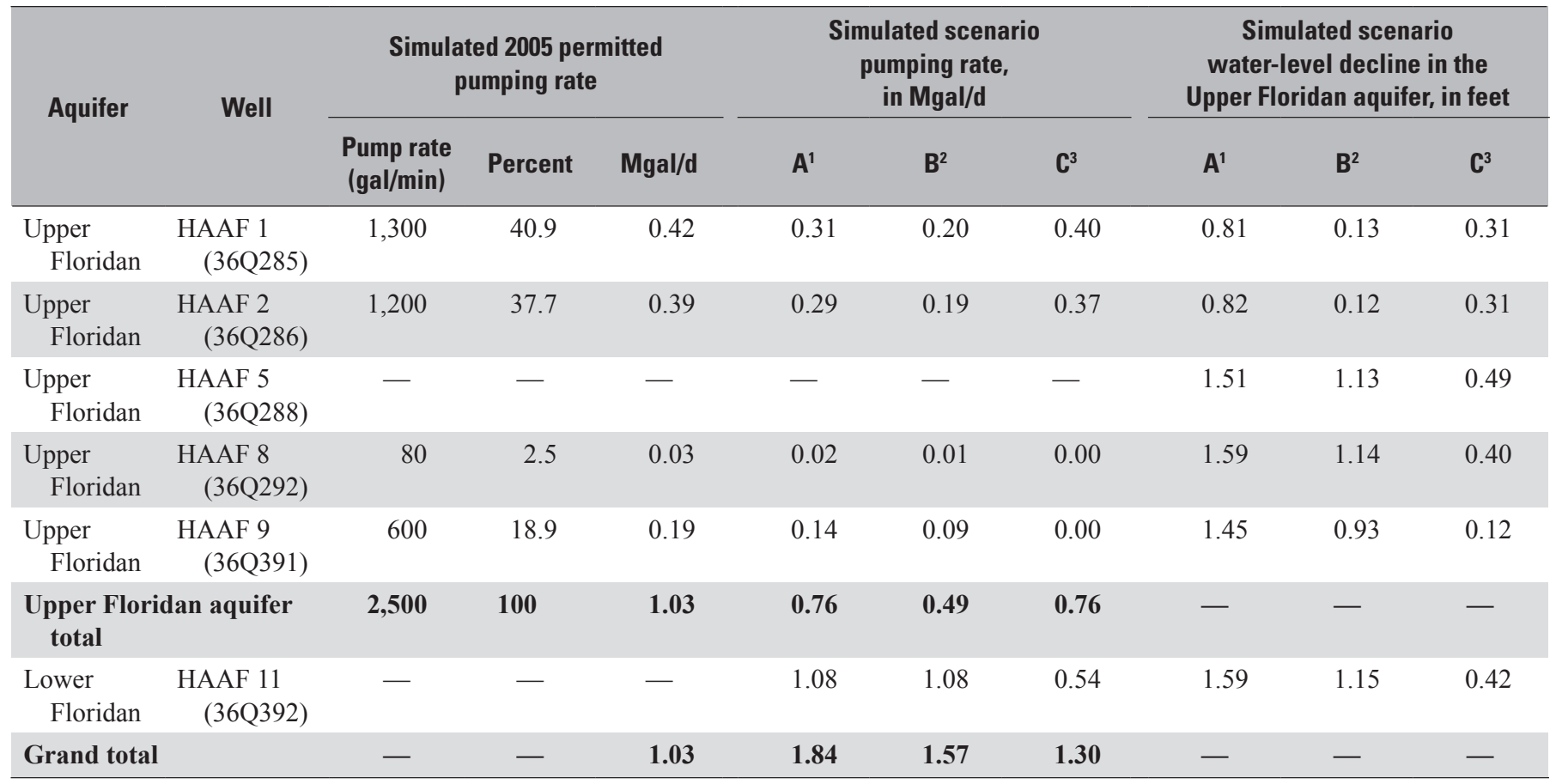

${ }^{1}$ Scenario A-Effect of pumping the Lower Floridan aquifer at well HAAF 11, 24 hours per day at a rate of $748 \mathrm{gal} / \mathrm{min}$ (1.08 Mgal/d), and reducing pumping in existing Upper Floridan aquifer HAAF supply wells by $187 \mathrm{gal} / \mathrm{min}(0.27 \mathrm{Mgal} / \mathrm{d})$ or 25 percent of well HAAF 11 pumping rate. The reduction in Upper Floridan pumping is close to the $189 \mathrm{gal} / \mathrm{min}$ rate required to match the maximum drawdown simulated near well HAAF 11.

${ }^{2}$ Scenario B-Effect of pumping the Lower Floridan aquifer at well HAAF 11, 24 hours per day at a rate of 748 gal $/ \mathrm{min}$ (1.08 Mgal/d), and reducing pumping in existing Upper Floridan aquifer HAAF supply wells by $374 \mathrm{gal} / \mathrm{min}(0.54 \mathrm{Mgal} / \mathrm{d})$ or 50 percent of well HAAF 11 pumping rate. The reduction in Upper Floridan aquifer pumping is close to the simulated steady state leakage rate of $361 \mathrm{gal} / \mathrm{min}$.

${ }^{3}$ Scenario C-Effect of pumping the Lower Floridan aquifer at well HAAF 11 at a rate of $374 \mathrm{gal} / \mathrm{min}(0.54 \mathrm{Mgal} / \mathrm{d})$, and reducing pumping in existing Upper Floridan aquifer HAAF supply wells by $187 \mathrm{gal} / \mathrm{min}(0.27 \mathrm{Mgal} / \mathrm{d})$ or 50 percent of well HAAF 11 pumping rate. Note all Upper Floridan aquifer pumping eliminated at wells HAAF 8 and HAAF 9 for this scenario. 

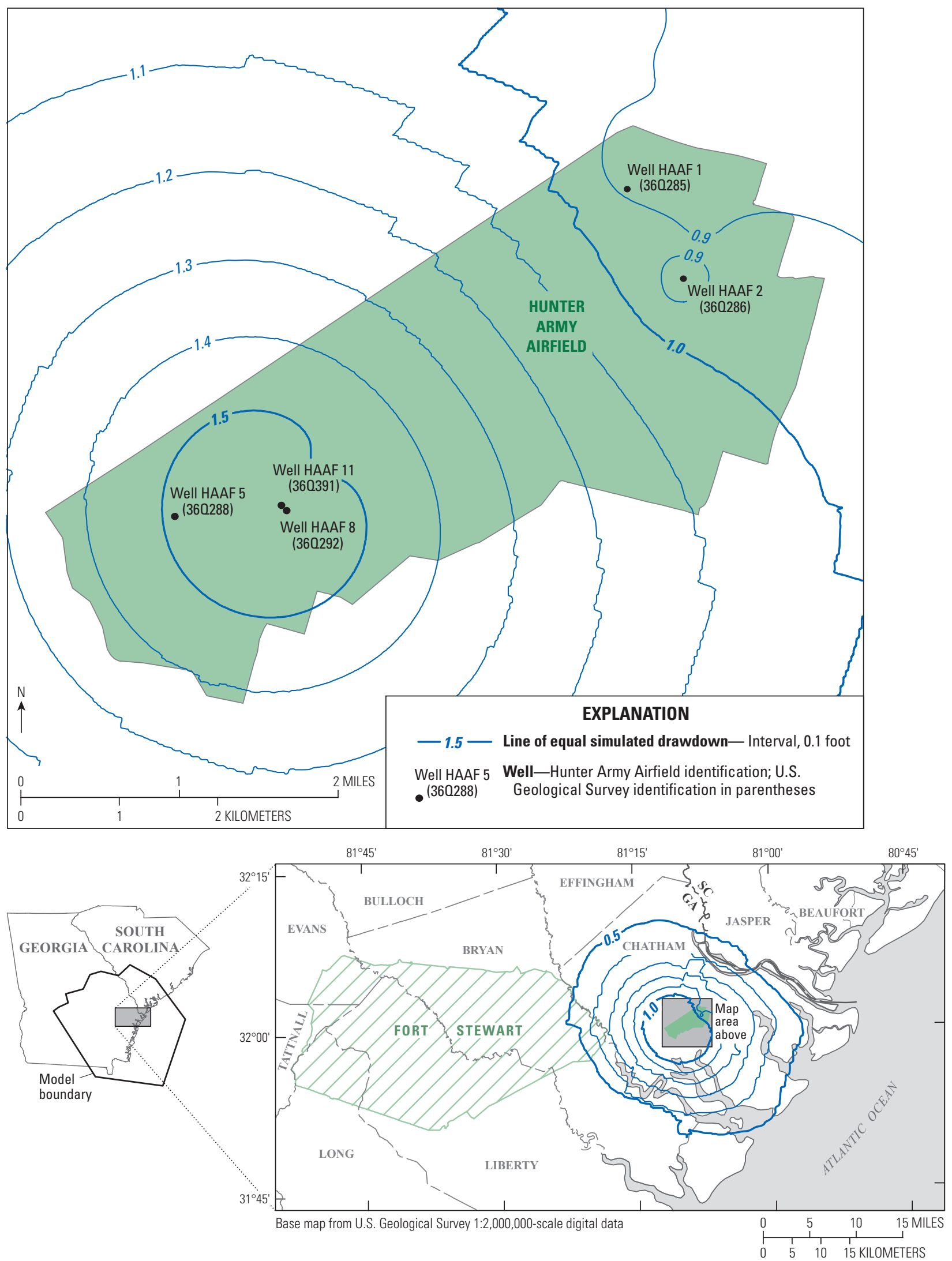

Figure 23. Drawdown in the Upper Floridan aquifer for scenario $\mathrm{A}$-effect of pumping the Lower Floridan aquifer at well HAAF 11 (360392) at a rate of 748 gallons per minute, and reducing pumping in existing Upper Floridan aquifer HAAF supply wells by 187 gallons per minute or 25 percent of well HAAF 11 (360392) pumping rate-Hunter Army Airfield and vicinity, coastal Georgia. 

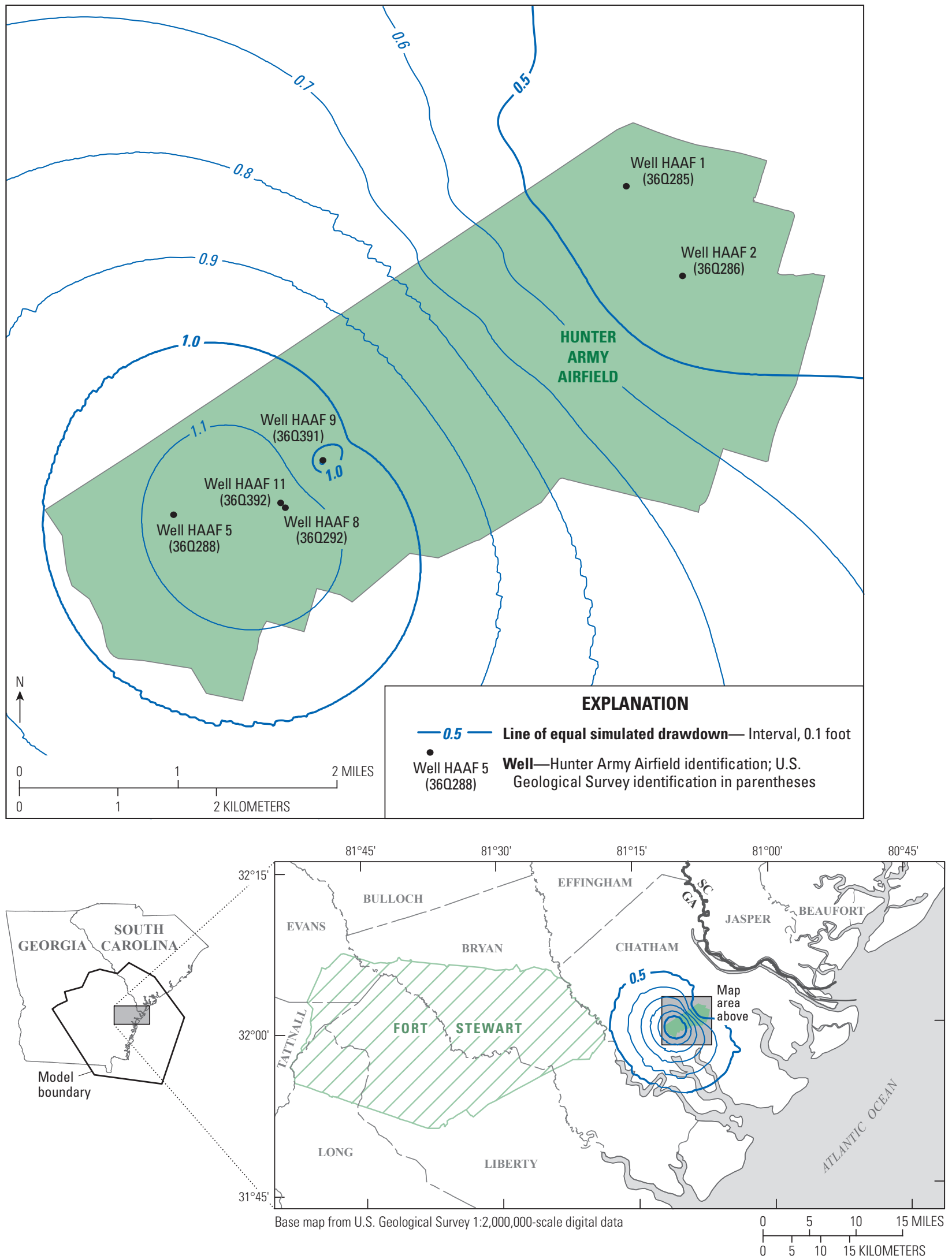

Figure 24. Drawdown in the Upper Floridan aquifer for scenario B - effect of pumping the Lower Floridan aquifer at well HAAF 11 (360392) at a rate of 748 gallons per minute, and reducing pumping in existing Upper Floridan aquifer supply wells by 374 gallons per minute or 50 percent of the well HAAF 11 (360392) pumping rate-Hunter Army Airfield and vicinity, coastal Georgia. 

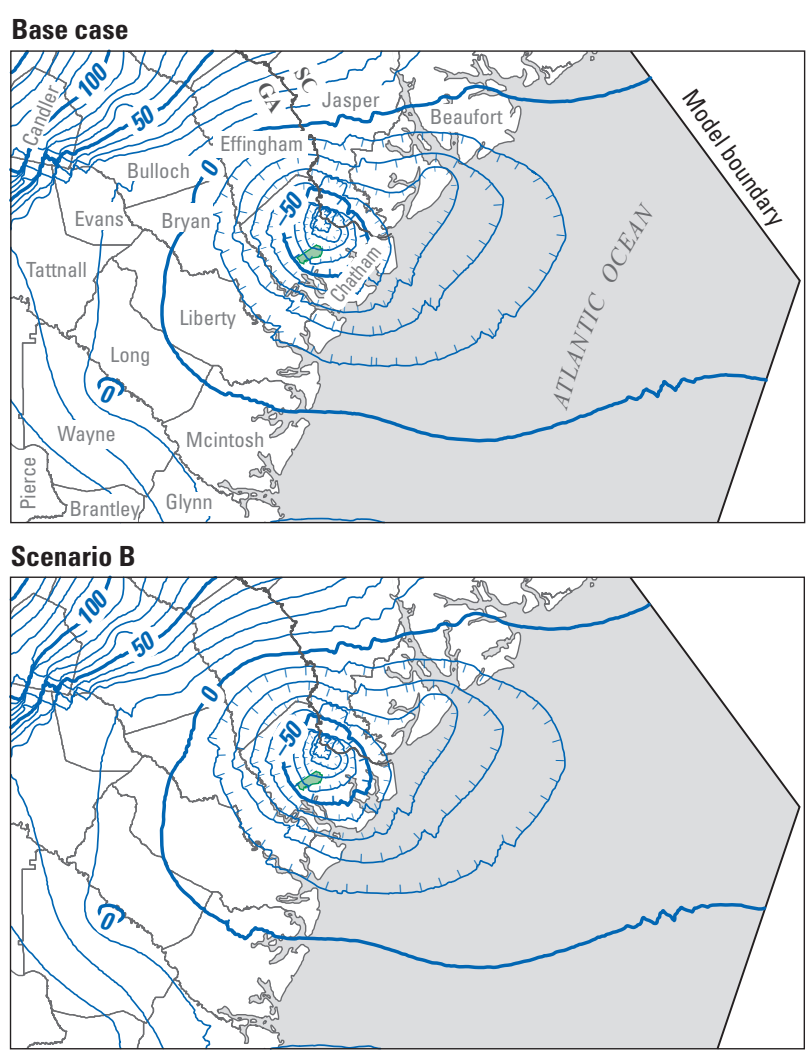

Base from U.S. Geological Survey

1:100,000-scale digital data

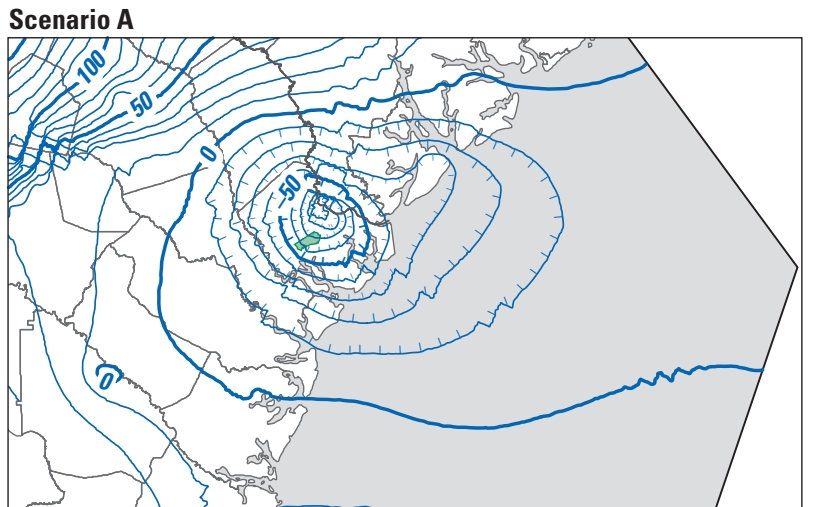

Scenario C

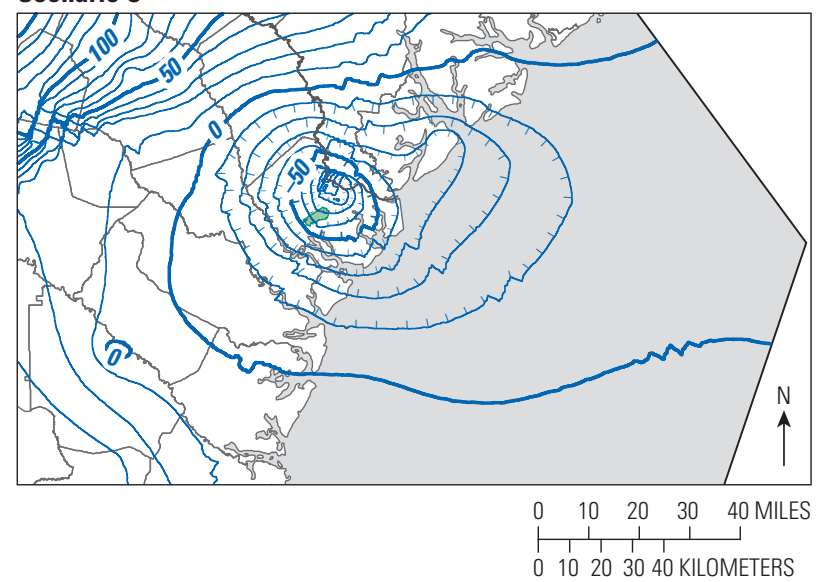

\section{EXPLANATION}

- 50 - Simulated potentiometric contour- Interval, 10 feet. Hachures indicate depression. Datum is NAVD 88

Figure 25. Simulated Upper Floridan aquifer potentiometric surfaces for the 2005 base case and scenarios A, B, and C, Hunter Army Airfield and vicinity, coastal Georgia.

\section{Effect of Pumping Offsets on Water Supply at Hunter Army Airfield}

The GaEPD interim strategy for permitting withdrawals from the LFA (Nolton Johnston, Georgia Environmental Protection Division, written commun., January 28, 2003) requires an applicant to

- "offset the impact of the LF [Lower Floridan] pumping by reducing nearby UF [Upper Floridan] permitted pumping in the same general area (within a 5 mile radius) by an amount equal to or greater than the determined UF leakage" and

- "simulate the equivalent Upper Floridan pumping that induces the identical maximum drawdown in the Upper Floridan that would be expected as a result of pumping the Lower Floridan."
Results of model scenarios indicate that these two requirements result in widely varying simulated pumping offsets for the UFA. Simulated interaquifer leakage from the UFA through the Lower Floridan confining unit into the LFA was $361 \mathrm{gal} / \mathrm{min}(0.52 \mathrm{Mgal} / \mathrm{d})$, whereas a pumping rate of $189 \mathrm{gal} / \mathrm{min}(0.27 \mathrm{Mgal} / \mathrm{d})$ in a hypothetical UFA well was needed in order to match simulated maximum drawdown in the UFA that resulted from interaquifer leakage. The simulated pumping rate needed to match the maximum drawdown in the UFA underpredicts the amount of pumping offset because the cone of depression formed in response to pumping the UFA is steeper near the pumped well and covers a smaller area than the area simulated in response to interaquifer leakage. Thus, the simulated leakage rate may be a more effective means of evaluating required pumping offsets. 
Changes in total permitted capacity at HAAF would vary based on the amount of reduction mandated by GaEPD. Described below are the required pumping reduction and net gain in production capacity at HAAF that would result if (1) the June 2010 revised UFA permit rate is assumed (0.98 Mgal/d), (2) pumping from the LFA is for a 24-hour period at a rate of $748 \mathrm{gal} / \mathrm{min}(1.08 \mathrm{Mgal} / \mathrm{d})$, and (3) the simulated leakage response (361 gal/min or $0.51 \mathrm{Mgal} / \mathrm{d}$ ) is used as the basis of the reduction:

- Because the simulated leakage rate is $0.51 \mathrm{Mgal} / \mathrm{d}$, the June 2010 UFA permit at HAAF would need to be reduced by $0.26 \mathrm{Mgal} / \mathrm{d}$ to a revised permitted withdrawal rate of $0.72 \mathrm{Mgal} / \mathrm{d}$,
- The new LFA permit would be based on a 24-hour per day pumping period at a withdrawal rate of $748 \mathrm{gal} / \mathrm{min}(1.08 \mathrm{Mgal} / \mathrm{d})$,

- The resulting water production would be the combined permitted rate of the UFA and LFA or $0.72 \mathrm{Mgal} / \mathrm{d}+1.08 \mathrm{Mgal} / \mathrm{d}=1.8 \mathrm{Mgal} / \mathrm{d}$.

Pumping offsets and net gain in water production capacity for a variety of pumping periods are listed in table 11 . For a 12-hour daily pumping period, the net gain in capacity would range from $0.28 \mathrm{Mgal} / \mathrm{d}$ (to meet the leakage requirement) to $0.4 \mathrm{Mgal} / \mathrm{d}$ (to meet the maximum drawdown requirement). For a 24-hour pumping period, the net gain in capacity would range from $0.56 \mathrm{Mgal} / \mathrm{d}$ (to meet the leakage requirement) to $0.8 \mathrm{Mgal} / \mathrm{d}$ (to meet the maximum drawdown requirement).

Table 11. Projected reductions in Upper Floridan aquifer permitted capacity and net gain in total water capacity for various pumping periods, well HAAF 11 (360392), Hunter Army Airfield, Chatham County, Georgia.

[gal/min; gallon per minute; Mgal/d, million gallons per day]

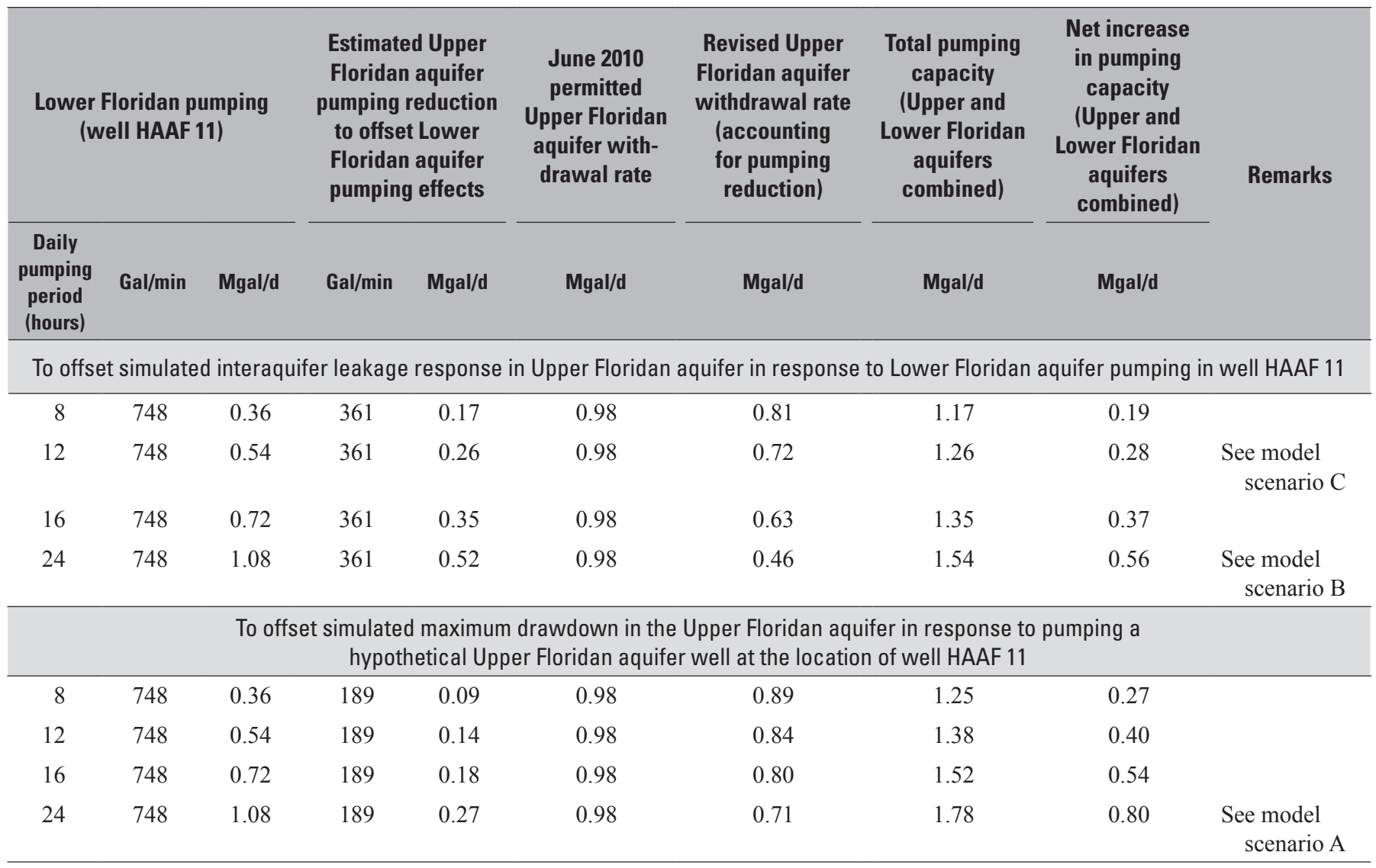




\section{Limitations of Analysis}

The effect of pumping the LFA on water levels in the UFA was analyzed using model simulation. These analyses are limited by the accuracy of field data, including possible errors and uncertainty in water-level measurements, hydraulic properties, and pumping. Although water-level data were filtered (Halford, 2006) in an attempt to eliminate local interferences, such as tidal and pumping effects, it is possible that some of these interferences still affect recorded levels and, thus, computed hydraulic properties and measured drawdown response.

A revised regional-flow model was used to simulate longterm (steady-state) changes in groundwater flow. Additional insight into changes in water levels over time could be gained by using transient simulation. The revised model reasonably depicts changes in groundwater levels resulting from pumping the LFA at HAAF at a rate of $748 \mathrm{gal} / \mathrm{min}$. Results are limited by the same model assumptions and design as described by Payne and others (2005). In addition to limitations of field data accuracy as described above, the revised model may have inaccuracies in the conceptual model of groundwater flow. For example, approximations made in representing the physical properties of the flow system and errors inherent in estimating the spatial distribution of these properties; approximations made in the formulation and application of model boundary and initial conditions; errors associated with numerical approximation and solution of the mathematical model of the flow system; and assumptions made in using the models to predict the future behavior of the flow system. The variably spaced mesh used in the revised model has an aspect ratio between row and column dimensions of as high as 1,646:1, which can lead to numerical errors (de Marsily, 1986, p. 351). Fortunately, such high aspect ratios occur only in areas distant from HAAF and will have little effect on simulated results in the area.

Simulated rates of interaquifer leakage and drawdown may be lower than actual because of the influence of specifiedhead and general-head boundaries. These boundaries supply an unlimited amount of water to the groundwater system, which may result in lower than actual simulated drawdown and related rates of interaquifer leakage. Simulation results could be improved by eliminating these types of boundaries and using active simulation of the surficial aquifer and by using lateral specified-flux boundaries.

\section{Summary and Conclusions}

To assess the hydrogeology and water quality of the Floridan aquifer system and the potential effect of Lower Floridan aquifer (LFA) pumping on the Upper Floridan aquifer (UFA), the U.S. Geological Survey, in cooperation with the Department of the Army, conducted an investigation at Hunter Army Airfield (HAAF) in Chatham County, Georgia, during 2009. The study included construction of a test well completed in the LFA, aquifer-performance testing, geophysical logging, water-quality sampling and analysis, and digital groundwater modeling.

Results of test drilling and field tests indicate the LFA at HAAF consists of limestone and dolomitic limestone between depths of 703 and 1,080 feet (ft). Six major permeable zones were identified through borehole-geophysical logging and flowmeter testing: 723-731; 768-785; 818-837; 917-923; $1,027-1,052$; and $1,060-1,080 \mathrm{ft}$. The two uppermost zones contribute about 469 gallons per minute (gal/min) or 62.6 percent of the total flow of $748 \mathrm{gal} / \mathrm{min}$. The remaining four zones each contributed from 1.7 to 18 percent of the total flow.

Grab water samples indicate water from the LFA is hard to very hard with a bicarbonate alkalinity of 150 to 250 milligrams per liter $(\mathrm{mg} / \mathrm{L})$. With the exception of fluoride, constituent concentrations increased with depth. Water from the deepest interval $(1,075 \mathrm{ft})$ has a chloride concentration of $480 \mathrm{mg} / \mathrm{L}$ and a sulfate concentration of $240 \mathrm{mg} / \mathrm{L}$, above and close to the U.S. Environmental Protection Agency (USEPA) secondary maximum contamination level for drinking water, respectively. Flowmeter testing indicates that water from the 1,075 -ft zone contributes less than 2 percent of the total flow to the well, so the relatively higher concentrations of chloride and sulfate in the deepest interval will not adversely affect the water quality in the completed well. A composite water-quality sample from the completed LFA well indicated constituent concentrations of the composite sample were all below USEPA primary and secondary maximum contaminant levels (U.S. Environmental Protection Agency, 2009).

To assess the effect of LFA pumping on the UFA, a 72-hour aquifer test was conducted in which LFA well HAAF 11 (36Q392) was pumped at an average rate of $748 \mathrm{gal} / \mathrm{min}$, and drawdown response was monitored in nearby UFA wells HAAF 5 (36Q288) and HAAF 8 (36Q292). At the end of 72 hours, total drawdown - after filtering data to remove the effects of regional pumping, tides, and barometric pressure - was $0.76 \mathrm{ft}$ in well HAAF 8 (36Q292) and $0.43 \mathrm{ft}$ in well HAAF 5 (36Q288).

A revised regional groundwater-flow model was used to simulate the long-term (steady-state) leakage response of the UFA to pumping from the LFA, and to estimate the equivalent amount of UFA pumping that would produce similar 
drawdown. The model incorporated data obtained during field testing at the site of well HAAF 11 and applied a fine grid resolution near that well to enable more accurate simulation at small scale.

Pumping well HAAF 11 (36Q392) at a rate of $748 \mathrm{gal} / \mathrm{min}$ (about 1 million gallons per day [Mgal/d] resulted in a maximum steady-state drawdown of $36.2 \mathrm{ft}$ in the LFA and was greater than $1 \mathrm{ft}$ over a 146 -square-mile $\left(\mathrm{mi}^{2}\right)$ area. Simulated steady-state drawdown in the overlying UFA that resulted from interaquifer leakage was greater than $1 \mathrm{ft}$ over a $141-\mathrm{mi}^{2}$ area and was $2.03 \mathrm{ft}$ at the site of well HAAF 11.

Pumping $1 \mathrm{Mgal} / \mathrm{d}$ at well HAAF 11 (36Q392) had a minor influence on the overall simulated water budget, with most of the change reflected by an increase in recharge from the overlying general head boundary. Although the overall budget changed little, there was a redistribution of flow in individual model layers. Flow to well HAAF 11 (36Q392) was derived by increased lateral flow from specified-head boundary $(0.02 \mathrm{Mgal} / \mathrm{d})$, increased leakage from the UFA through the Lower Floridan confining unit (0.52 Mgal/d), and reductions in discharge to the Lower Floridan confining unit $(0.53 \mathrm{Mgal} / \mathrm{d})$ and to lateral specified-head boundaries $(0.53 \mathrm{Mgal} / \mathrm{d})$. Sixty-five percent of the leakage from the UFA occurred within 1 mile of well HAAF 11. This larger contribution results from a larger head gradient between the pumped well and overlying aquifer in areas close to the pumped well.

As part of the interim permitting strategy for the LFA, the Georgia Environmental Protection Division (GaEPD) required simulation of (1) aquifer leakage from the UFA to LFA resulting from pumping the new LFA well, and (2) "the equivalent Upper Floridan pumping that induces the identical maximum drawdown in the Upper Floridan that would be expected as a result of pumping the Lower Floridan." Results of this analysis can be used as a basis to reduce nearby UFA permitted pumping in the same general area (within a 5-mi radius) by an amount equal to or greater than the determined leakage rate. Results of model simulations indicate that these two requirements result in widely varying pumping offsets for the UFA. Simulated interaquifer leakage was $361 \mathrm{gal} / \mathrm{min}$ $(0.52 \mathrm{Mgal} / \mathrm{d})$, whereas the equivalent UFA pumping rate to offset maximum drawdown was $189 \mathrm{gal} / \mathrm{min}(0.27 \mathrm{Mgal} / \mathrm{d})$. The simulated pumping rate necessary to match the maximum drawdown in the UFA underpredicts the amount of pumping offset because the cone of depression formed in response to pumping the UFA is steeper near the pumped well and covers a smaller area than the area simulated in response to interaquifer leakage. Thus, the simulated leakage rate may be a more effective means of evaluating required pumping offsets.

Three groundwater pumping scenarios were run to evaluate the effect of various pumping changes on groundwater levels at HAAF:
- Scenario A-Effect of pumping the LFA at well HAAF 11, for 24 hours per day at a rate of $748 \mathrm{gal} / \mathrm{min}$ $(1.08 \mathrm{Mgal} / \mathrm{d})$, and reducing pumping in existing UFA HAAF supply wells by $187 \mathrm{gal} / \mathrm{min}(0.27 \mathrm{Mgal} / \mathrm{d})$ or 25 percent of the pumping rate at well HAAF 11 (36Q392). The reduction in withdrawals from the UFA is close to the $189 \mathrm{gal} / \mathrm{min}$ rate required to match the maximum drawdown simulated near well HAAF 11.

- Scenario B-Effect of pumping the LFA at well HAAF 11, for 24 hours per day at a rate of $748 \mathrm{gal} / \mathrm{min}$ (1.08 Mgal $/ \mathrm{d})$, and reducing pumping in existing UFA HAAF supply wells by $374 \mathrm{gal} / \mathrm{min}(0.54 \mathrm{Mgal} / \mathrm{d})$ or 50 percent of the pumping rate at well HAAF 11 (36Q392). The reduction in withdrawals from the UFA is close to the simulated steady state leakage rate of $361 \mathrm{gal} / \mathrm{min}$.

- Scenario C-Effect of pumping the LFA at well HAAF 11 (36Q392) at a rate of $374 \mathrm{gal} / \mathrm{min}$ $(0.54 \mathrm{Mgal} / \mathrm{d})$, and reducing pumping in existing UFA HAAF supply wells by $187 \mathrm{gal} / \mathrm{min}(0.27 \mathrm{Mgal} / \mathrm{d})$ or 50 percent of the pumping rate at well HAAF 11 (36Q392). Note that all withdrawals from the UFA at wells HAAF 8 (36Q292) and HAAF 9 (36Q391) were eliminated for this scenario.

For each scenario, pumping reductions in existing HAAF UFA wells resulted in decreased magnitude and extent of drawdown when compared to a scenario in which the LFA was pumped without adjusting withdrawals from the UFA. Pumping from the LFA well HAAF 11 (36Q392) without adjusting pumping from the UFA resulted in drawdown exceeding $1 \mathrm{ft}$ over a $141 \mathrm{mi}^{2}$, whereas drawdown exceeding $1 \mathrm{ft}$ covered areas of $40.5 \mathrm{mi}^{2}$ for scenario A and $4.37 \mathrm{mi}^{2}$ for scenario B. Drawdown was less than $0.5 \mathrm{ft}$ for scenario C. None of the scenarios resulted in noticeable changes in the configuration of the simulated potentiometric surface and related groundwater flow directions for the UFA.

GaEPD requires a reduction in permitted UFA withdrawals in order to offset simulated rates of leakage and maximum drawdown in the UFA. Once these reductions are accounted for, the net gain in water production capacity would be the difference between the maximum pumping rate in well HAAF 11 (36Q392) and the pumping offset. Changes in total permitted capacity at HAAF would vary on the basis of which amount of reduction is mandated by GaEPD. For a 12-hour daily pumping period, the net gain in capacity would range from $0.28 \mathrm{Mgal} / \mathrm{d}$ (to meet the leakage requirement) to $0.4 \mathrm{Mgal} / \mathrm{d}$ (to meet the maximum drawdown requirement). For a 24-hour pumping period, the net gain in capacity would range from 0.56 to $0.8 \mathrm{Mgal} / \mathrm{d}$. 


\section{Selected References}

ASTM D5079-08 Standard practices for preserving and transporting rock core samples: American Society for Testing and Materials, accessed November 9, 2009, at http://www.astm.org/Standards/D5079.htm.

ASTM D5084-03 Standard test methods for measurement of hydraulic conductivity of saturated porous materials using a flexible wall permeameter: American Society for Testing and Materials, accessed November 9, 2009, at http://www.astm.org/Standards/D5084.htm.

Bouwer, H., and Rice, R.C., 1976, A slug test method for determining hydraulic conductivity of unconfined aquifers with completely or partially penetrating wells: Water Resources Research, v. 12, no. 3, p. 423-428.

Clarke, J.S., 2003, The surficial and Brunswick aquifer systems-Alternative ground-water resources for coastal Georgia, in Hatcher, K.J., ed., Proceedings of the 2003 Georgia Water Resources Conference, April 23-24, 2003, The University of Georgia, Institute of Ecology, Athens, GA, CD-ROM.

Clarke, J.S., Hacke, C.M., and Peck, M.F., 1990, Geology and ground-water resources of the coastal area of Georgia: Georgia Geologic Survey Bulletin 113, 106 p.

Clarke, J.S., Leeth, D.C., Taylor-Harris, DáVette, Painter, J.A., and Labowski, J.L., 2004, Summary of hydraulic properties of the Floridan aquifer system in coastal Georgia and adjacent parts of South Carolina and Florida: U.S. Geological Survey Scientific Investigations Report 2004-5264, 50 p.

Cooper, H.H., Jr., Bredehoeft, J.D., and Papadopulos, I.S., 1967, Response of a finite-diameter well to an instantaneous charge of water: Water Resources Research, v. 3, no. 1, p. 263-269.

Cooper, H.H., and Jacob, C.E., 1946, A generalized graphical method for evaluating formation constants and summarizing well field history: American Geophysical Union Transactions, v. 27 , p. $526-534$.

Counts, H.B., and Donsky, Ellis, 1963, Salt-water encroachment, geology, and ground-water resources of Savannah area, Georgia and South Carolina: U.S. Geological Survey Water-Supply Paper 1611, 100 p.

de Marsily, Ghislain, 1986, Quantitative hydrogeology: Orlando, FL, Academic Press, Inc., 440 p.
Falls, W.F., Baum, J.S., Harrelson, L.G., Brown, L.H., and Jerden, J.L., Jr., 1997, Geology and hydrogeology of Cretaceous and Tertiary strata, and confinement in the vicinity of the U.S. Department of Energy Savannah River Site, South Carolina: U.S. Geological Survey WaterResources Investigations Report 97-4245, 125 p.

Falls, W.F., Harrelson, L.G., Conlon, K.J., and Petkewich, M.D., 2005, Hydrogeology, water quality, and water-supply potential of the Lower Floridan aquifer, coastal Georgia 1999-2002: U.S. Geological Survey Scientific Investigations Report 2005-5124, 98 p.

Ferris, J.G., Knowles, D.B., Brown, R.H., and Stallman, R.W., 1962, Theory of aquifer tests: U.S. Geological Survey Water-Supply Paper 1536-E, 174 p.

Freeze, R.A., and Cherry, J.A, 1979, Groundwater: Englewood Cliffs, NJ, Prentice-Hall, Inc., 604 p.

Gregg, D.O., and Zimmerman, E.A., 1974, Geologic and hydrologic control of chloride contamination in aquifers at Brunswick, Glynn County, Georgia: U.S. Geological Water-Supply Paper 2029-D, 44 p.

Halford, K.J., 2006, Documentation of a spreadsheet for timeseries analysis and drawdown estimation: U.S. Geological Survey Scientific Investigations Report 2006-5024, 38 p.

Hantush, M.S., 1960, Modification of the theory of leaky aquifers: Journal of Geophysical Research, v. 65, no. 11, p. 3713-3725.

Hantush, M.S., and Jacob, C.E., 1955, Non-steady flow in an infinite leaky aquifer: Transactions of the American Geophysical Union, v. 36, p. 95-100.

Harbaugh, A.W., 1990, A computer program for calculating subregional water budgets using results from the U.S. Geological Survey modular three-dimensional finite-difference ground-water flow model: U.S. Geological Survey OpenFile Report 90-392, 46 p.

Holloway, O.G., and Waddell, J.P., 2008, Design and operation of a borehole straddle packer for groundwater sampling and hydraulic testing of discrete intervals at U.S. Air Force Plant 6, Marietta, Georgia: U.S. Geological Survey OpenFile Report 2008-1349, 24 p.

Krause, R.E., and Clarke, J.S., 2001, Coastal ground water at risk-Saltwater contamination at Brunswick, Georgia, and Hilton Head Island, South Carolina: U.S. Geological Survey Water-Resources Investigations Report 01-4107, available online at http://ga2.er.usgs.gov/coastal/coastalreport.cfm, accessed March 19, 2010. 
Krause, R.E., and Randolph, R.B., 1989, Hydrology of the Floridan aquifer system in southeast Georgia and adjacent parts of Florida and South Carolina: U.S. Geological Survey Professional Paper 1403-D, 65 p., 18 pl.

McCollum, M.J., and Counts, H.B., 1964, Relation of saltwater encroachment to the major aquifer zones, Savannah area, Georgia and South Carolina: U.S. Geological Survey Water-Supply Paper 1613-D, 26 p.

Miller, J.A., 1986, Hydrogeologic framework of the Floridan aquifer system in Florida and in parts of Georgia, Alabama, and South Carolina: U.S. Geological Survey Professional Paper 1403-B, 91 p., 33 pl.

Payne, D.F., Abu Rumman, Malek, and Clarke, J.S., 2005, Simulation of ground-water flow in coastal Georgia and adjacent parts of South Carolina and Florida-Predevelopment, 1980, and 2000: U.S. Geological Survey Scientific Investigations Report 2005-5089, 91 p., accessed July 25, 2005, at http://pubs.usgs.gov/sir/2005/5089/.

Peaceman, D.W., 1983. Interpretation of well-block pressures in mumerical reservoir simulation with nonsquare grid blocks and anisotropic permeability: Society of Petroleum Engineers Journal, v. 23, no. 3, p. 531-543.

Priest, Sherlyn, 2004, Stream-aquifer relations in the coastal area of Georgia and adjacent parts of Florida and South Carolina: Georgia Geologic Information Circular 108, 40 p.
Ransom, Camille, III, and White, J.I., 1999, Potentiometric surface of the Floridan aquifer system in southern South Carolina: South Carolina Department of Health and Environmental Control, Bureau of Water Publication No. 02B-99, 1 sheet.

Reilly, T.E., and Harbaugh, A.W., 2004, Guidelines for evaluating groundwater flow models: U.S. Geological Survey Scientific Investigations Report 2004-5038, 30 p.

Theis, C.V., 1935, Relation between the lowering of the piezometric surface and the rate and duration of discharge of a well using groundwater storage: American Geophysical Union Transcripts, pt. 2, p. 519-524; dupl., as U.S. Geological Survey Groundwater Note 5, 1952.

U.S. Environmental Protection Agency, 2009, Drinking water contaminants, accessed August 19, 2009, at http://www.epa. gov/safewater/contaminants/index.html\#listmcl.

Wait, R.L., 1965, Geology and occurrence of fresh and brackish water in Glynn County, Georgia: U.S. Geological Survey Water-Supply Paper 1613-E, 94 p.

Warner, Debbie, and Aulenbach, B.T., 1999, Hydraulic characteristics of the Upper Floridan aquifer in the Savannah and St. Marys areas of coastal Georgia: Georgia Geologic Survey Information Circular 105, 23 p.

Williams, L.J., 2010, Summary of hydrologic testing of the Floridan aquifer system at Hunter Army Airfield, Chatham County, Georgia: U.S. Geological Survey Open-File Report 2010-1066, 30 p. 



\section{Appendix. Groundwater Model}

\section{Contents}

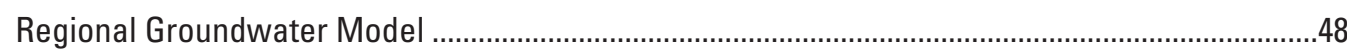

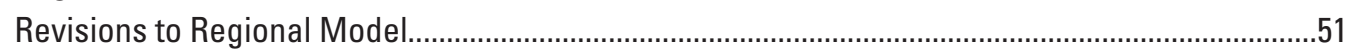

Refinement of Hydraulic Conductivity Distribution .............................................................

Simulation of Observed Drawdown in Pumped Well...............................................................53

Comparison of Revised to Original Regional Model .......................................................................53

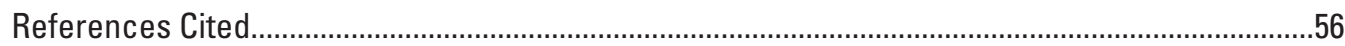

\section{Figures}

A-1. Maps showing location of selected wells, regional groundwater model and boundary conditions, and revised model grid Hunter Army Airfield and vicinity, coastal Georgia...

A-2. Schematic diagram showing model layers and boundary conditions .............................50

A-3. Schematic diagram showing simulated hydraulic property zones by model layer.........52

A-4. Maps showing difference between simulated and observed water levels (residuals) by model layer for 2000, revised regional flow model: Brunswick aquifer system (layer 3), Upper Floridan aquifer (layer 5), and Lower Floridan aquifer (layer 7)

A-5. Graphs showing observed and simulated water levels in model layers 3, 5, and 7 revised groundwater model

\section{Tables}

A-1. Comparison of water-level calibration statistics between the original and revised regional models, year 2000 steady-state simulation

A-2. Comparison of simulated water budget by model layer between the original and revised regional models, year 2000 simulation 


\section{Regional Groundwater Model}

The existing USGS regional groundwater-flow model (herein termed "regional model" ) of Payne and others (2005) was modified using hydrogeological information obtained from field investigations and from existing wells in the vicinity of Hunter Army Airfield (HAAF) to simulate pumping from the newly constructed Lower Floridan aquifer well (HAAF 11, 36Q392) and the effect on the Upper Floridan aquifer. The regional model is described in detail in Payne and others (2005); only a brief description is included here. The regional model was calibrated for predevelopment, 1980, and 2000 pumping and boundary conditions. Because pumpage during 2009 was within the range simulated by the earlier regional model, the revised model was deemed suitable for the evalution of groundwater flow at HAAF.

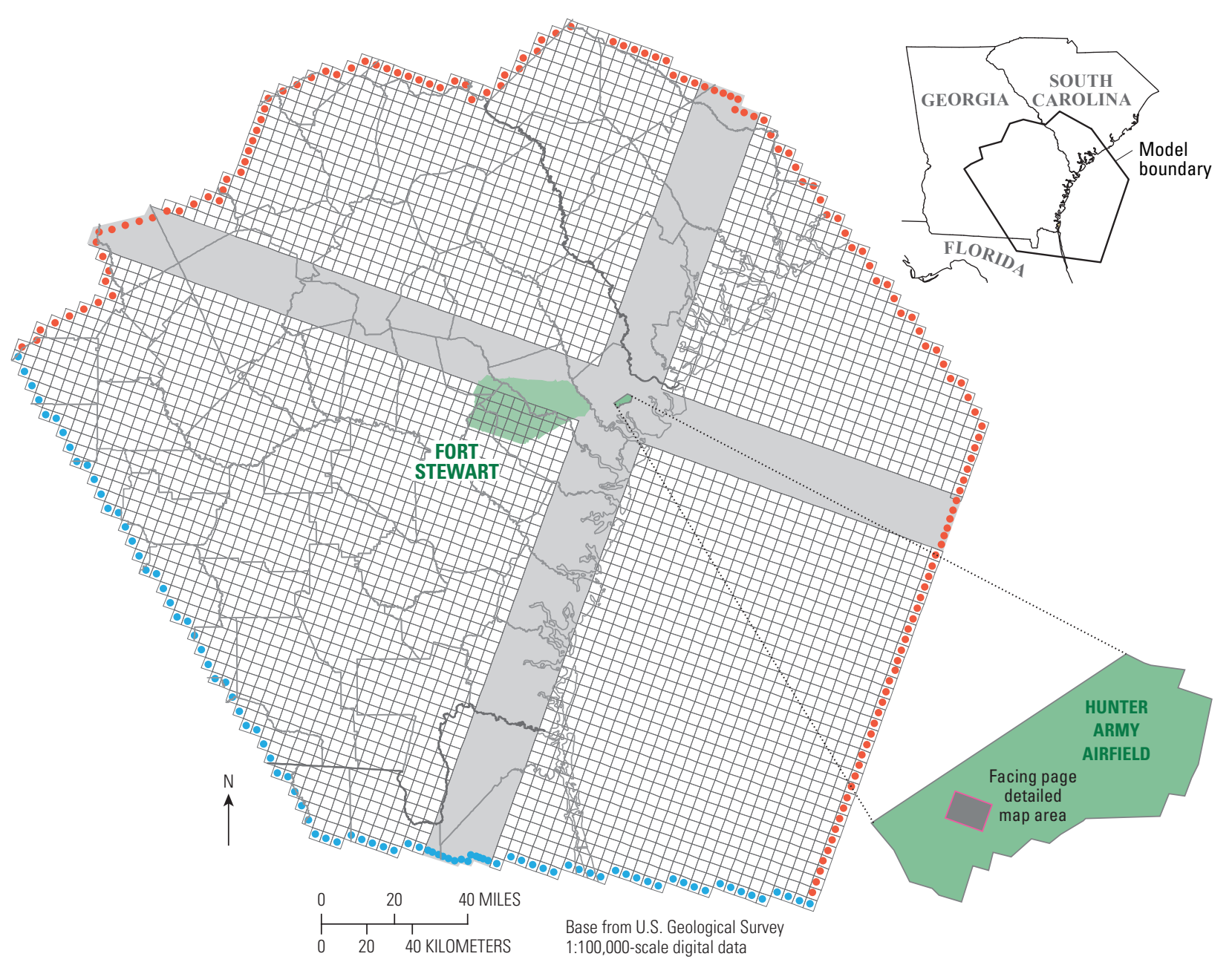

EXPLANATION

\section{$\otimes$ Model grid with uniform spacing of 16,461 feet by 16,461 feet}

Area of dense model grid-Size progressively increased by a factor of 1.5 from the smallest grid spacing of 10 feet to a spacing of 16,461 feet

\section{Model boundary \\ - Specified head \\ - No-flow}

Figure A-1. Location of selected wells, regional groundwater model and boundary conditions, and revised model grid Hunter Army Airfield and vicinity, coastal Georgia. 
Regional groundwater flow was simulated using MODFLOW-2000 (Harbaugh and others, 2000), a finitedifference, constant-density flow simulator that is widely used and is appropriate for modeling local- and regional-scale groundwater-flow systems. To account for natural hydrologic boundaries, the model area covers a 42,155 square-mile $\left(\mathrm{mi}^{2}\right)$ area extending inland in Georgia and into northeastern Florida and southwestern South Carolina, and the adjacent offshore area (fig. A-1).

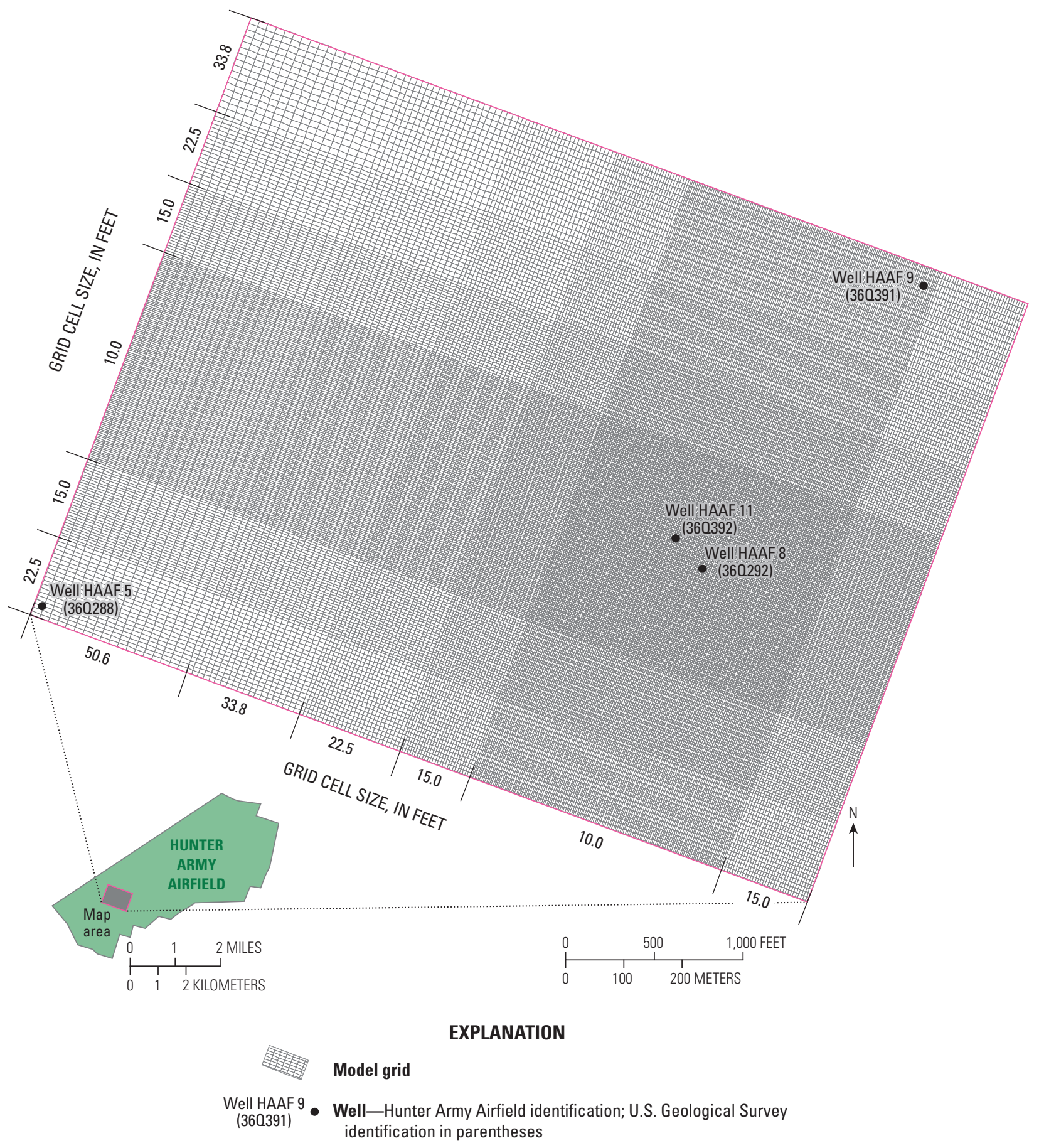

Figure A-1. Location of selected wells, regional groundwater model and boundary conditions, and revised model grid Hunter Army Airfield and vicinity, coastal Georgia.-Continued 
The regional model (Payne and others, 2005) was calibrated for 1980 and 2000 pumping conditions assuming steady-state flow. The regional model consists of seven hydrogeologic units (fig. A-2), which include, in descending order:

- the confined upper and lower water-bearing zones of the surficial aquifer system, grouped together as layer 1;

- the Brunswick aquifer system confining unit (layer 2);

- the upper and lower Brunswick aquifers, grouped as the Brunswick aquifer system (layer 3);

- the Upper Floridan aquifer confining unit (layer 4);

- the Upper Floridan aquifer (layer 5);

- the Lower Floridan aquifer confining unit (layer 6); and

- the Lower Floridan aquifer (layer 7).
These units crop out to the northwest of the study area and generally dip and thicken to the southeast. The thickness, extent, and other hydraulic properties of these units as well as the model development process are described in detail in Payne and others (2005). A schematic diagram showing model layers and boundary conditions is shown in figure A-2.

The original regional model was horizontally discretized using a variably spaced grid, with cell sizes ranging from approximately $4,000 \times 5,000$ feet $(\mathrm{ft})\left(0.7 \mathrm{mi}^{2}\right)$ to $16,500 \times 16,500 \mathrm{ft}\left(9.8 \mathrm{mi}^{2}\right)$. At HAAF, the mesh resolution is $5,000 \times 5,200 \mathrm{ft}$, whereas at Fort Stewart the resolution is $14,900 \times 16,100 \mathrm{ft}$. Each hydrogeologic unit is represented with one layer of grid cells in the vertical dimension.

With the exception of layers 5, 6, and 7 (Upper and Lower Floridan aquifers and intervening confining unit), lateral boundaries for all layers are designated as noflow. For layers 5,6 , and 7 , the lateral boundaries on all sides of the

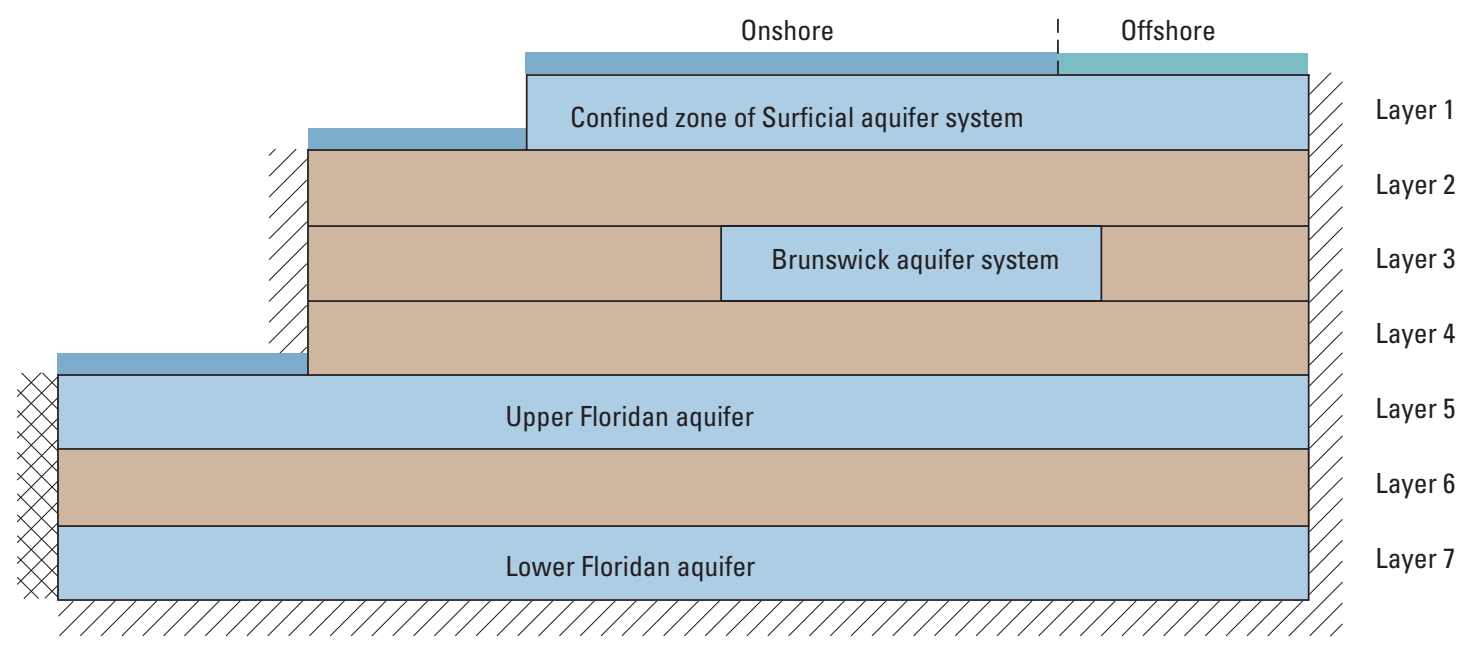

EXPLANATION

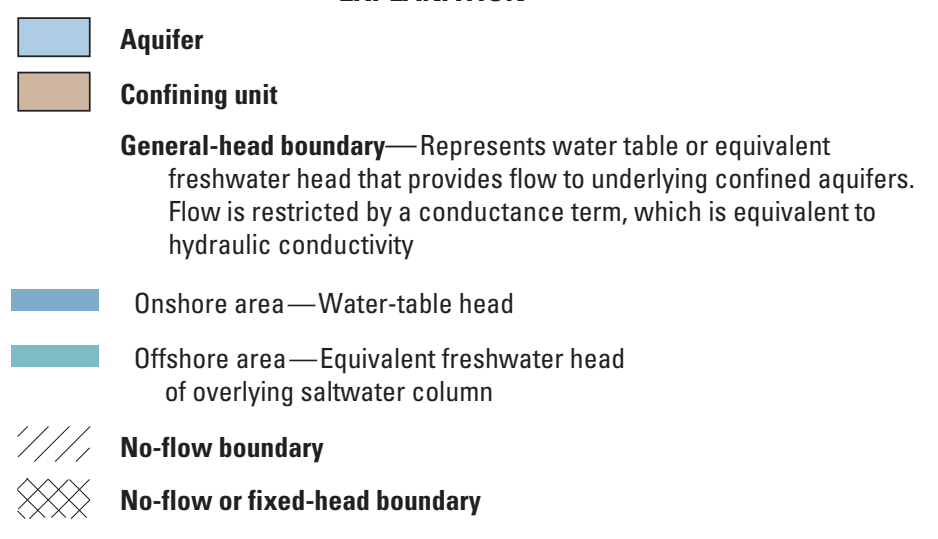

Figure A-2. Schematic diagram showing model layers and boundary conditions (from Payne and others, 2005). 
model, except for the southern and southwestern sides, also are designated as noflow. The southern and southwestern lateral boundaries are set as specified head for the layers representing the Upper Floridan aquifer (layer 5), the Lower Floridan aquifer (layer 7), and the intervening confining unit (layer 6). For these three layers, the value assigned to specified-head cells is based on Upper Floridan aquifer head estimated from potentiometric-surface maps for 1998 (Peck and others, 1999).

The bottom boundary of the regional model is noflow, corresponding to the lower confiing unit of the Floridan aquifer system, whereas the top boundary is set as a head-dependent flux (or general head) boundary condition with a controlling specified head and a conductance term that regulates the flux into the top layer of the model. The controlling head is the water-table altitude in the onshore area and the freshwater equivalent of the saltwater head in the offshore area. In the onshore area, the conductance is set to limit the amount of recharge entering the system in any given grid cell to lessthan-maximum estimated recharge from baseflow estimates (Priest, 2004). For the purpose of simplification and because little is known about hydraulic properties in the offshore area, the conductance imposed in the offshore area is large, posing minimal resistance to flow in or out of the system.

Pumping distribution was assigned based on countyaggregate and site-specific data, which were used to estimate average annual pumpage for 1980 and 2000. Pumpage was assigned to model layers 3 (Brunswick aquifer system), 5 (Upper Floridan aquifer), and 7 (Lower Floridan aquifer) based on the open interval of wells located within a model cell. The sum of site-specific and nonsite-specific pumping rates for 1980 and 2000 were assigned to the model cell in which their respective assigned locations and aquifers were situated. Total pumpage simulated by the model during 1980 was $692 \mathrm{Mgal} / \mathrm{d}$, by 2000 this had risen to $798 \mathrm{Mgal} / \mathrm{d}$.

\section{Revisions to Regional Model}

A steady-state simulation was conducted using the model of Payne and others (2005) in which well HAAF 11 (36Q392) was pumped at a rate of 748 gallons per minute ( $\mathrm{gal} / \mathrm{min}$ ) and drawdown response was recorded. Simulated Upper Floridan aquifer drawdown was $4.13 \mathrm{ft}$ at well HAAF 8 (36Q292) and $3.08 \mathrm{ft}$ at well HAAF 5 (36Q288); Lower Floridan aquifer drawdown was $222 \mathrm{ft}$ at well HAAF 11 (36Q392). The amount of drawdown simulated in the Lower Floridan aquifer was more than six times greater than the $36.3 \mathrm{ft}$ of drawdown observed in well HAAF 11 (36Q392) during a 72-hour aquifer test in which drawdown appeared to have mostly stabilized. This excessive drawdown indicated that modification of the model was needed.

The regional model was modified to enable more detailed simulation in the vicinity of the new Lower Floridan aquifer well (HAAF 11, 36Q392) and surrounding area. Grid-cell dimensions were modified to a variably spaced grid (fig. A-1) that was progressively increased by a factor of 1.5 from the smallest grid spacing of $10 \mathrm{ft}$ near well HAAF 11 (36Q392) to a spacing of $16,461 \mathrm{ft}$, which was held constant to the lateral extent of the model. The revised model consists of 452 rows and 530 columns. Model layering and boundary conditions remained unchanged from the original regional model.

\section{Refinement of Hydraulic Conductivity Distribution}

Values of vertical and horizontal hydraulic conductivity $\left(\mathrm{K}_{\mathrm{v}}, \mathrm{K}_{\mathrm{h}}\right)$ in the revised model corresponded to values used in the original regional model (Payne and others, 2005) in the area outside of HAAF. Field testing at HAAF provided new information on the hydraulic properties of the Upper Floridan aquifer (layer 5), Lower Floridan confining unit (layer 6), and Lower Floridan aquifer (layer 7), and enabled refinement of values in the original regional model. In addition, results of a 72-hour aquifer test conducted in the Lower Floridan aquifer provided information on drawdown in the Lower Floridan aquifer and in the overlying Upper Floridan aquifer, which guided a revised calibration of the model in the vicinity of HAAF within the larger regional model. Maps showing the distribution of hydraulic- property zones by model layer are shown in figure A-3.

To incorporate refined hydraulic-property information, new hydraulic-property zones were created in the Upper Floridan aquifer (zone F13), Lower Floridan aquifer (zone LF2) and intervening Lower Floridan confining layer (zone LFC2). These zones cover a $114.5 \mathrm{mi}^{2}$ common area that includes HAAF and the area of highest grid resolution, and extend from western Chatham County into eastern Bryan County (fig. A-3).

For the Upper Floridan aquifer (layer 5), zone F13 was subdivided from existing regional model zone F4, and assigned a $\mathrm{K}_{\mathrm{v}}$ and $\mathrm{K}_{\mathrm{h}}$ value of 76 feet per day ( $\left.\mathrm{ft} / \mathrm{d}\right)$, which is slightly higher than the $70 \mathrm{ft} / \mathrm{d}$ value assigned in the original regional model. This modification was based on results of aquifer testing conducted in wells HAAF 9 (36Q291) and HAAF 8 (36Q292). Multiplying this $\mathrm{K}_{\mathrm{h}}$ value by the simulated thickness of the aquifer (526 ft) gives an estimated transmissivity of 40,000 square feet per day $\left(\mathrm{ft}^{2} / \mathrm{d}\right)$, matching results of field testing at HAAF.

In the original regional model (Payne and others, 2005), the Lower Floridan confining unit (layer 6) was assigned a constant $\mathrm{K}_{\mathrm{h}}$ and $\mathrm{K}_{\mathrm{v}}$ value of $0.02 \mathrm{ft} / \mathrm{d}$; in the revised model, zone LFC2, covering an identical area as zone F13, was subdivided from this single zone and assigned a $\mathrm{K}_{\mathrm{h}}$ value of $0.2 \mathrm{ft} / \mathrm{d}$ and a $\mathrm{K}_{\mathrm{v}}$ value of $0.02 \mathrm{ft} / \mathrm{d}$ (fig. A-3). These values were based on adjustments made during model calibration and are at the lower end of the range of estimated values derived from packer-slug tests and core analysis at well HAAF 11 (36Q392). 


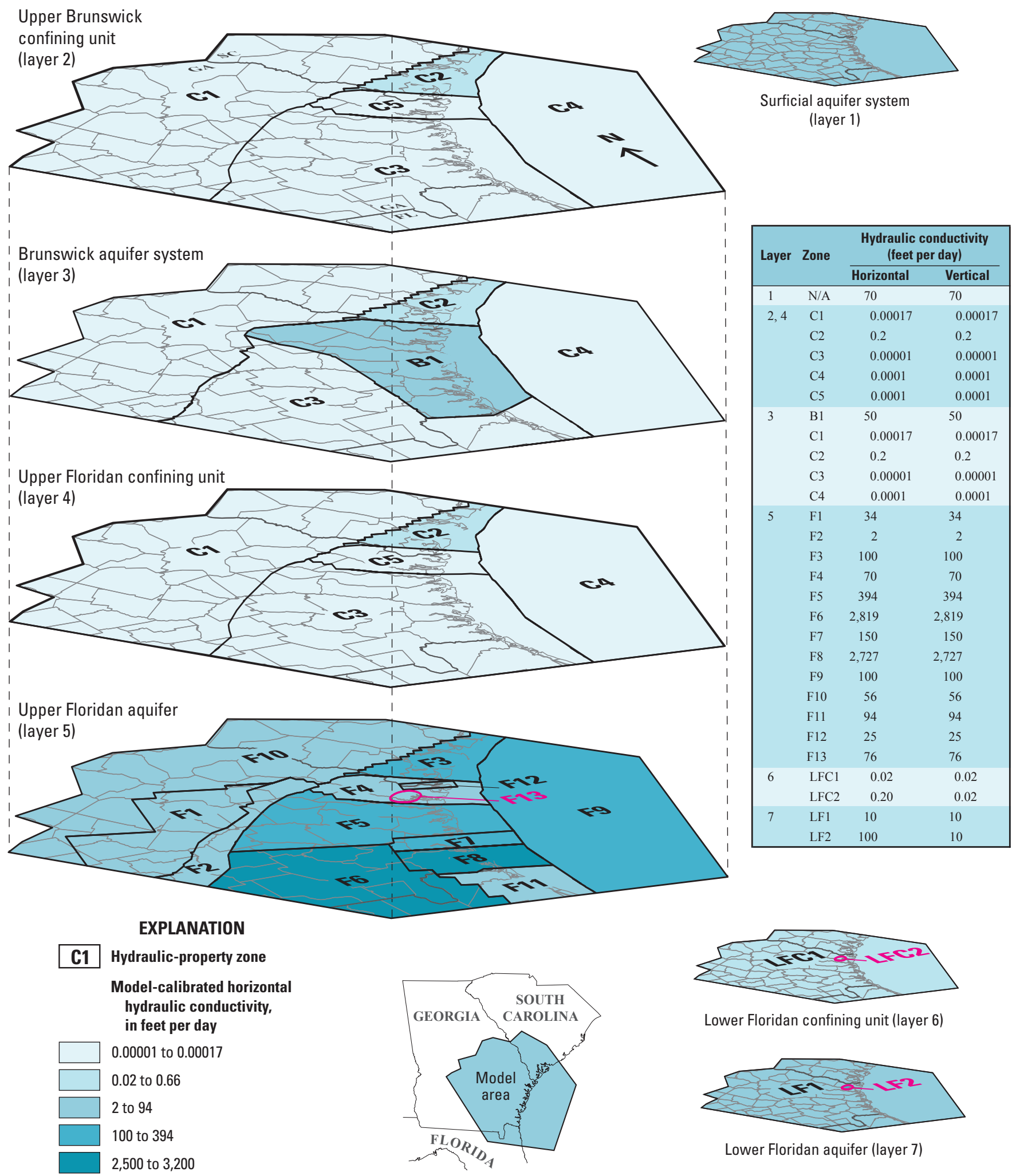

Figure A-3. Schematic diagram showing simulated hydraulic property zones by model layer. Zone added for updated model shown in magenta (modified from Payne and others, 2005). 
In model layer 7, which represents the Lower Floridan aquifer, zone LF2 was subdivided from a single zone that was previously assigned a uniform $\mathrm{K}_{h}$ and $\mathrm{K}_{\mathrm{v}}$ value of $10 \mathrm{ft} / \mathrm{d}$ in the original regional model of Payne and others (2005). Zone LF2 covers an identical area as zones F13 and LFC2 and was assigned $a K_{h}$ value of $100 \mathrm{ft} / \mathrm{d}$ and $a K_{v}$ value of $10 \mathrm{ft} / \mathrm{d}$ on the basis of results of aquifer testing conducted in well HAAF 11 (36Q392). Multiplying the $\mathrm{K}_{\mathrm{h}}$ value by the regionalmodel-assigned thickness for the Lower Floridan aquifer of $70 \mathrm{ft}$, gives a transmissivity of $7,000 \mathrm{ft}^{2} / \mathrm{d}$, which is similar in magnitude to the $11,000 \mathrm{ft}^{2} / \mathrm{d}$ value computed from an aquifer test conducted in well HAAF 11 (36Q392). $\mathrm{K}_{\mathrm{v}}$ of the Lower Floridan aquifer in zone LF2 was $10 \mathrm{ft} / \mathrm{d}$ based on an assumed 10:1 ratio of horizontal to vertical properties.

\section{Simulation of Observed Drawdown in Pumped Well}

Drawdown calculated by the MODFLOW model represents the average drawdown for the grid cell, which is less than that observed in an individual pumped well. Because the grid cell size used in the MODFLOW simulation at the pumped well $\left(10 \mathrm{ft}^{2}\right)$ is much larger than the well diameter $(0.33 \mathrm{ft})$, the drawdown calculated by the MODFLOW model at the pumped well needs to be proportionately increased on the basis of well diameter to provide a more precise estimate of drawdown. Simulated drawdown was adjusted using the following equation (Peaceman, 1983):

$$
\mathrm{S}_{\mathrm{p}}=\mathrm{Sb}+\left[\mathrm{Q} * \ln \left(\mathrm{r}_{\mathrm{e}} / \mathrm{r}_{\mathrm{w}}\right) / 2 \pi\left(\mathrm{T}_{\mathrm{xx}} \mathrm{T}_{\mathrm{yy}}\right)^{0.5}\right]
$$

where:

$$
\begin{gathered}
\mathrm{S}_{\mathrm{p}} \quad \begin{array}{l}
\text { is the adjusted drawdown in the } \\
\text { pumped well, in feet; }
\end{array} \\
\mathrm{S}_{\mathrm{b}} \quad \text { is the MODFLOW simulated drawdown } \\
\text { in the pumped well, in feet; } \\
\mathrm{Q} \quad \text { is the pump discharge, in cubic feet } \\
\text { per day (144,000); } \\
\mathrm{r}_{\mathrm{e}} \quad \text { is the equivalent well block radius, } \\
\text { in feet (5); } \\
\mathrm{r}_{\mathrm{w}} \quad \text { is the well radiusin feet }(0.33) \text {; } \\
\mathrm{T}_{\mathrm{xx}} \quad \text { is the transmissivity in the } \mathrm{x}-\text { direction, } \\
\text { in feet squared per day }(7,000) \text {; and } \\
\mathrm{T}_{\mathrm{yy}} \quad \text { is the transmissivity in the y-direction, } \\
\text { in feet squared per day }(7,000) \text {. }
\end{gathered}
$$

Use of this equation indicated that simulated values in the model cell containing well HAAF 11 (36Q392) when pumped at a rate of $748 \mathrm{gal} / \mathrm{min}$ would would be $8.9 \mathrm{ft}$ less than the observed drawdown. A similar analysis for an Upper Floridan aquifer well pumped at a rate of $650 \mathrm{gal} / \mathrm{min}$ and using the same parameters, with the exception of a value of $40,000 \mathrm{ft}^{2} / \mathrm{d}$ for transmissivity, indicates that simulated values for a pumped well in this aquifer would require an adjustment of about $1.36 \mathrm{ft}$.

\section{Comparison of Revised to Original Regional Model}

Because the original regional model of Payne and others (2005) was modified by changing grid size and by assigning different hydraulic properties in the vicinity of HAAF, a comparison of the two models is provided to ensure the model is still an accurate representation of groundwater flow. Summaries of water-level residuals (simulated minus observed head) and simulated water budgets for the two models are presented (tables A-1 and A-2). Water-level residuals for the Upper and Lower Floridan aquifers are shown on maps plotted in figure A-4 and graphically in figure A-5.

Model results indicate that the revised regional model has water-level residuals and a simulated water budget similar to the original model of Payne and others (2005), and thus, the model remains equally representative of the hydrologic system (tables A-1, A-2). These results are expected because model revisions are limited to a $114.5 \mathrm{mi}^{2}$ area representing less than 1 percent of the model area. Water-level residuals for the revised regional model were slightly higher than those calculated from the original model for layers 5 and 7, with root mean square (RMS) of 10.2 and $9.91 \mathrm{ft}$, respectively (table A-1). Eighty percent of the residuals for layer 5 derived from the revised model were within -3.8 to $2.9 \mathrm{ft}$ of the original regional model residuals.

The RMS of water-level residuals for layer $3(11 \mathrm{ft})$ in the revised model was nearly double that in the original regional model $(5.91 \mathrm{ft})$ but is acceptable for the purpose of the modified model. Simulated water levels in 8 of 10 wells in layer 3 showed residuals that increased by 0.34 to $3.4 \mathrm{ft}$ when compared to the orginal regional model. Most of the increase in the RMS for layer 3 can be attributed to two wells that had water-level residuals of $-19 \mathrm{ft}$ (figs. A-4, A-5). These wells are located adjacent to one another in the same model cell, in an area where the grid size of the revised model was more than four times greater than in the original regional model. This larger grid size reduced the capability of the model to simulate steeper gradients in the vicinity of the Savannah area cone of depression and resulted in a greater residual. Because the larger grid size and related increase in RMS for layer 3 occurred away from the area of higher grid resolution in the vicinity of HAAF, model simulations at HAAF were not affected.

Simulated water budgets for the regional and revised models were similar, with only slight variation (table A-2). The revised model showed a slight increase in interaction with lateral boundaries and a slight decrease in interaction with the overlying general head boundary, specifically, (1) overall decreases in recharge from and discharge to the overlying general-head boundary, and (2) decreased outflow and increased inflow along lateral specified-head boundaries. 
Table A-1. Comparison of water-level calibration statistics between the original (Payne and others, 2005) and revised regional models, year 2000 steady-state simulation.

[Residual equals simulated minus observed head]

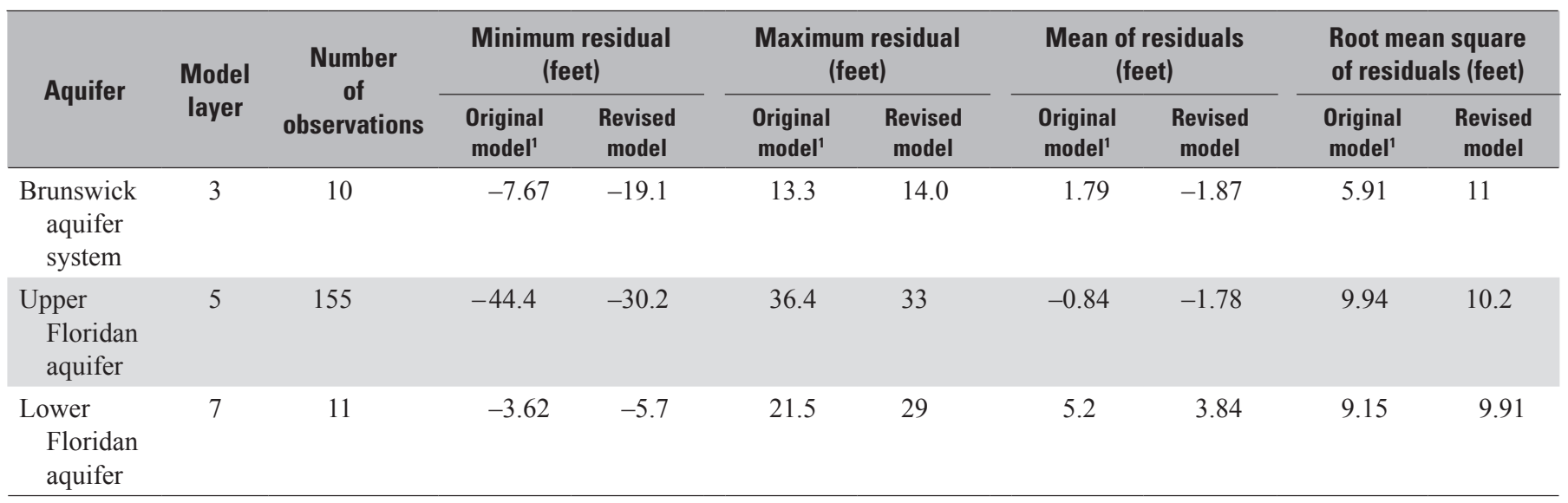

${ }^{1}$ Original model by Payne and others, 2005.

Table A-2. Comparison of simulated water budget by model layer between the original (Payne and others, 2005) and revised regional models, year 2000 simulation

[Values reported to three significant digits and may not sum to totals because of independent rounding; $<$, less than]

\begin{tabular}{|c|c|c|c|c|c|c|c|c|c|c|c|}
\hline \multirow{3}{*}{$\begin{array}{l}\text { Hydro- } \\
\text { geologic } \\
\text { unit }\end{array}$} & \multirow{3}{*}{$\begin{array}{l}\text { Model } \\
\text { layer }\end{array}$} & \multicolumn{10}{|c|}{ Simulated flow in million gallons per day } \\
\hline & & \multicolumn{2}{|c|}{ Pumpage } & \multicolumn{2}{|c|}{$\begin{array}{l}\text { Recharge from } \\
\text { general-head } \\
\text { boundary }\end{array}$} & \multicolumn{2}{|c|}{$\begin{array}{c}\text { Discharge to } \\
\text { general-head } \\
\text { boundary }\end{array}$} & \multicolumn{2}{|c|}{$\begin{array}{l}\text { Inflow along } \\
\text { lateral boundary }\end{array}$} & \multicolumn{2}{|c|}{$\begin{array}{l}\text { Outflow along } \\
\text { lateral boundary }\end{array}$} \\
\hline & & $\begin{array}{l}\text { Original } \\
\text { model' }\end{array}$ & $\begin{array}{l}\text { Revised } \\
\text { model }\end{array}$ & $\begin{array}{l}\text { Original } \\
\text { model }\end{array}$ & $\begin{array}{l}\text { Revised } \\
\text { model }\end{array}$ & $\begin{array}{l}\text { Original } \\
\text { model' }\end{array}$ & $\begin{array}{l}\text { Revised } \\
\text { model }\end{array}$ & $\begin{array}{c}\text { Original } \\
\text { model }^{1}\end{array}$ & $\begin{array}{l}\text { Revised } \\
\text { model }\end{array}$ & $\begin{array}{l}\text { Original } \\
\text { model' }\end{array}$ & $\begin{array}{c}\text { Revised } \\
\text { model }\end{array}$ \\
\hline $\begin{array}{l}\text { Confining } \\
\text { unit }\end{array}$ & 2 & $<0.001$ & $<0.001$ & 46.6 & 46.1 & 3.62 & 4.70 & $<0.001$ & $<0.001$ & $<0.001$ & $<0.001$ \\
\hline $\begin{array}{l}\text { Brunswick } \\
\text { aquifer } \\
\text { system }\end{array}$ & 3 & 0.241 & 0.241 & $<0.001$ & $<0.001$ & $<0.001$ & $<0.001$ & $<0.001$ & $<0.001$ & $<0.001$ & $<0.001$ \\
\hline $\begin{array}{l}\text { Upper } \\
\text { Floridan } \\
\text { aquifer }\end{array}$ & 5 & 669 & 669 & 141 & 145 & 22.3 & 22.1 & 712 & 715 & 268 & 266 \\
\hline $\begin{array}{l}\text { Confining } \\
\text { unit }\end{array}$ & 6 & $<0.001$ & $<0.001$ & $<0.001$ & $<0.001$ & $<0.001$ & $<0.001$ & 0.004 & 0.004 & $<0.001$ & $<0.001$ \\
\hline $\begin{array}{l}\text { Lower } \\
\text { Floridan } \\
\text { aquifer }\end{array}$ & 7 & 129 & 129 & $<0.001$ & $<0.001$ & $<0.001$ & $<0.001$ & 15.5 & 16.6 & 2.32 & 1.97 \\
\hline \multicolumn{2}{|c|}{ Total all layers } & 798 & 798 & 498 & 465 & 158 & 129 & 728 & 732 & 270 & 268 \\
\hline
\end{tabular}


A. Brunswick aquifer system (layer 3)

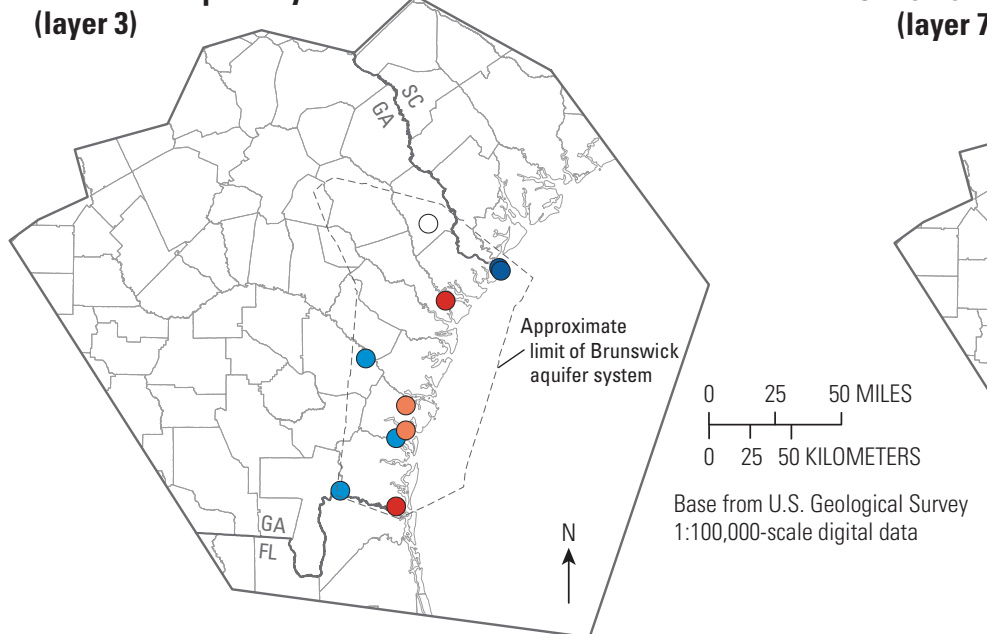

C. Lower Floridan aquifer (layer 7)

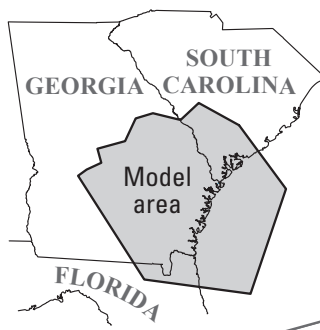

\section{B. Upper Floridan} aquifer (layer 5)

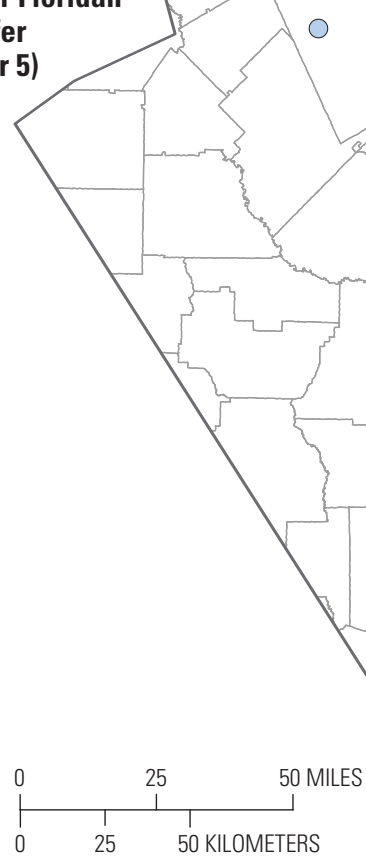

Base from U.S. Geological Survey 1:100,000-scale digital data

Figure A-4. Difference between simulated and observed water levels (residuals) by model layer for 2000, revised regional flow model: (A) Brunswick aquifer system (layer 3), (B) Upper Floridan aquifer (layer 5 ), and (C) Lower Floridan aquifer (layer 7). 


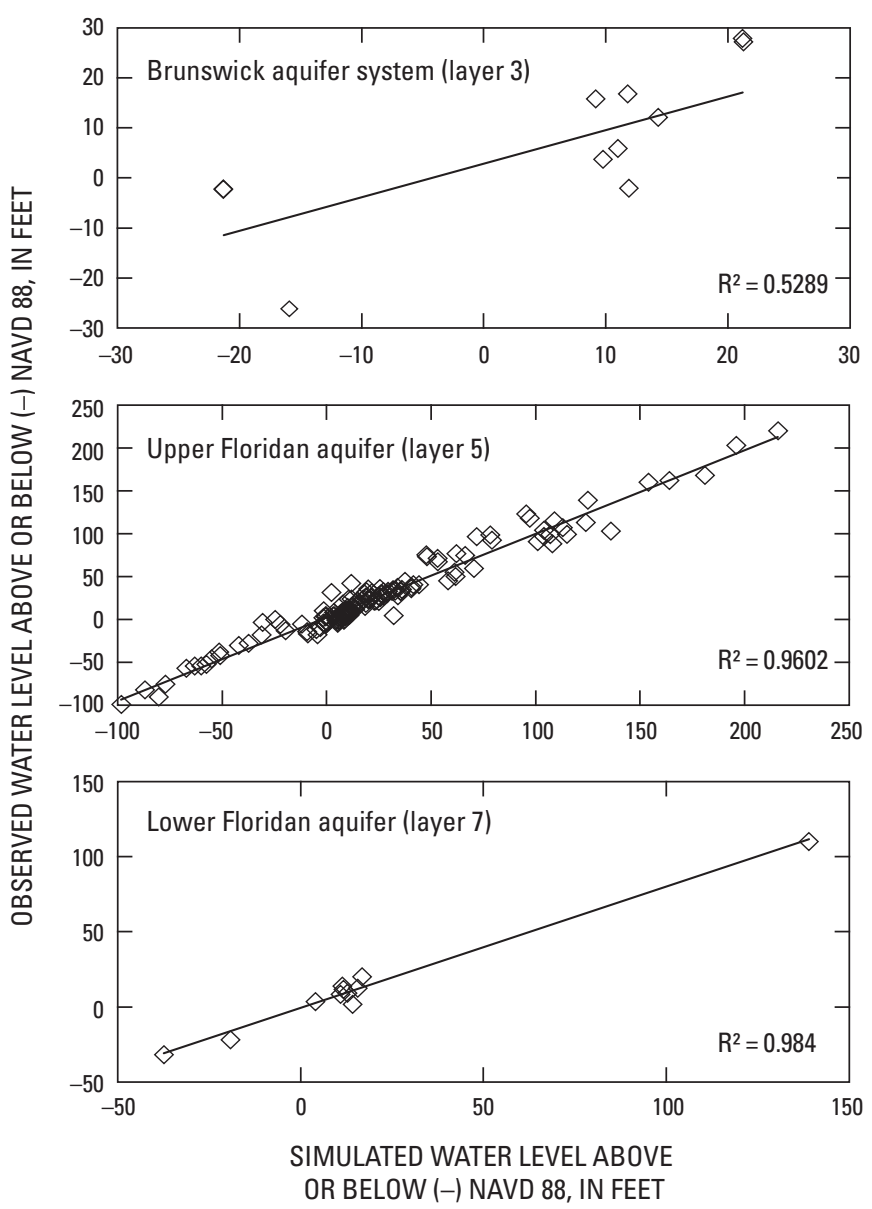

Figure A-5. Observed and simulated water levels in model layers 3, 5, and 7 revised groundwater model.

\section{References Cited}

Harbaugh, A.W., 1990, A computer program for calculating subregional water budgets using results from the U.S. Geological Survey modular three-dimensional finite-difference ground-water flow model: U.S. Geological Survey OpenFile Report 90-392, 46 p.

Harbaugh, A.W., Banta, E.R., Hill, M.C., and McDonald, M.G., 2000, MODFLOW-2000, The U.S. Geological Survey modular ground-water model-User guide to modularization concepts and the ground-water flow process: U.S. Geological Survey Open-File Report 00-92, 121 p., accessed March 23, 2010, at http://pubs.er.usgs.gov/ usgspubs/ofr/ofr2000-92.

Payne, D.F., Abu Rumman, Malek, and Clarke, J.S., 2005, Simulation of ground-water flow in coastal Georgia and adjacent parts of South Carolina and Florida-Predevelopment, 1980, and 2000: U.S. Geological Survey Scientific Investigations Report 2005-5089, 91 p., accessed March 23, 2010, at http://pubs.usgs.gov/sir/2005/5089/.

Peaceman, D.W., 1983, Interpretation of well-block pressures in numerical reservoir simulation with nonsquare grid blocks and anisotropic permeability: Society of Petroleum Engineers Journal, v. 23, no. 3, p. 531-543.

Peck, M.F., Clarke, J.S., Ransom, Camille, III, and Richards, C.J., 1999, Potentiometric surface of the Upper Floridan aquifer in Georgia and adjacent parts of Alabama, Florida, and South Carolina, May 1998, and water level-trends in Georgia, 1990-98: Georgia Geologic Survey Hydrologic Atlas 22, 1 sheet.

Priest, Sherlyn, 2004, Stream-aquifer relations in the coastal area of Georgia and adjacent parts of Florida and South Carolina: Georgia Geologic Information Circular 108, 40 p. 
Manuscript approved on April 13, 2010

For more information about this publication, contact: USGS Georgia Water Science Center

3039 Amwiler Road

Atlanta, GA 30360

telephone: 770-903-9100

http://ga.water.usgs.gov/

Edited by Kay E. Hedrick

Illustrations by Bonnie J. Turcott

Layout by Caryl J. Wipperfurth 
